Florida International University FIU Digital Commons

$3-25-2015$

\title{
Identity, Ideology, and Cinema: Making Sense of Japan's Foreign and Security Policies in the 1950s and 2000s
}

Yukari Ito

Florida International University, yutz76@gmail.com

DOI: $10.25148 /$ etd.FI15032159

Follow this and additional works at: https://digitalcommons.fiu.edu/etd

Part of the International Relations Commons

\section{Recommended Citation}

Ito, Yukari, "Identity, Ideology, and Cinema: Making Sense of Japan's Foreign and Security Policies in the 1950s and 2000s" (2015). FIU Electronic Theses and Dissertations. 1835.

https://digitalcommons.fiu.edu/etd/1835 


\section{FLORIDA INTERNATIONAL UNIVERSITY}

Miami, Florida

\section{IDENTITY, IDEOLOGY, AND CINEMA: MAKING SENSE OF JAPAN'S FOREIGN} AND SECURITY POLICIES IN THE 1950s AND 2000s

A dissertation submitted in partial fulfillment of

the requirements for the degree of

DOCTOR OF PHILOSOPHY

in

INTERNATIONAL RELATIONS

by

Yukari Ito

2015 
To: Dean Michael R. Heithaus

College of Arts and Sciences

This dissertation, written by Yukari Ito, and entitled Identity, Ideology, and Cinema: Making Sense of Japan's Foreign and Security Policies in the 1950s and 2000s, having been approved in respect to style and intellectual content, is referred to you for judgment.

We have read this dissertation and recommend that it be approved.

Thomas Breslin

\begin{tabular}{rr}
\hline Harry Gould \\
\hline Steven Heine
\end{tabular}

Paul Kowert

John Clark, Major Professor

Date of Defense: March 25, 2015

The dissertation of Yukari Ito is approved.

\begin{tabular}{r} 
Dean Michael R. Heithaus \\
College of Arts and Sciences \\
\hline Dean Lakshmi N. Reddi \\
University Graduate School
\end{tabular}

Florida International University, 2015 
C Copyright 2015 by Yukari Ito

All rights reserved. 


\section{DEDICATION}

To my mother Shizuko and father Tsuneo. For their love, patience, and support. 


\section{ACKNOWLEDGMENTS}

I would like to express my deepest appreciation to my former committee chair and member of my committee, Dr. Paul Kowert. I have benefitted greatly from his extremely intelligent and helpful suggestions. Dr. Kowert has helped me to develop my project since the beginning, and I cannot thank him enough for his tremendous kindness and support throughout the process of completing my dissertation.

My heartfelt appreciation goes to my committee chair, Dr. John Clark. I cannot thank him enough for his tremendously generous support to finalize my project. Without his extremely helpful guidance and continuous encouragement, the completion of this dissertation would not have been possible.

I also would like to thank my committee members, Dr. Harry Gould, Dr. Thomas Breslin, and Dr. Steven Heine. I am extremely thankful to Dr. Gould who is my committee member and graduate director. He has continuously given me kind encouragement and support and I would not have been able to continue my project without his help. I also could not thank Dr. Breslin and Dr. Heine enough for their generous and patient support. Dr. Breslin and Dr. Heine have both given me very insightful suggestions and comments that I have greatly benefitted from.

I am thankful to my family for everything they have given to me. Also, my special thanks go to my husband, Adam Weiner, who has patiently supported me throughout this journey. 


\begin{abstract}
OF THE DISSERTATION
IDENTITY, IDEOLOGY, AND CINEMA: MAKING SENSE OF JAPAN'S FOREIGN
\end{abstract}

AND SECURITY POLICIES IN THE 1950s AND 2000s

by

Yukari Ito

Florida International University, 2015

Miami, Florida

Professor John Clark, Major Professor

Japan is an important ally of the United States-the world's third biggest economy, and one of the regional great powers in Asia. Making sense of Japan's foreign and security policies is crucial for the future of peace and stability in Northeast Asia, where the possible sources of conflict such as territorial disputes or the disputes over Japan's war legacy issues are observed.

This dissertation explored Japan's foreign and security policies based on Japan's identities and unconscious ideologies. It employed an analysis of selected Japanese films from the late 1940 s to the late $1950 \mathrm{~s}$, as well as from the late 1990 s to the mid-2000s. The analysis demonstrated that Japan's foreign and security policies could be understood in terms of a broader social narrative that was visible in Japanese popular cultural products, including films and literatures. Narratives of Japanese families from the patriarch's point of view, for example, had constantly shaped Japan's foreign and security policies. As a result, the world was ordered hierarchically in the eyes of the Japan Self. In the 1950 s, Japan tenaciously constructed close but asymmetrical security relations with 
the U.S. in which Japan willingly subjugated itself to the U.S. In the 2000s, Japan again constructed close relations with the U.S. by doing its best to support American responses to the $9 / 11$ terrorist attacks by mobilizing Japan's SDFs in the way Japan had never done in the past.

The concepts of identity and unconscious ideology are helpful in understanding how Japan's own understanding of self, of others, and of the world have shaped its own behaviors. These concepts also enable Japan to reevaluate its own behaviors reflexively, which departs from existing alternative approaches. This study provided a critical analytical explanation of the dynamics at work in Japan's sense of identity, particularly with regard to its foreign and security policies. 


\section{TABLE OF CONTENTS}

CHAPTER

PAGE

CHAPTER 1: INTRODUCTION TO IDENTITY, IDEOLOGY, AND CINEMA ............1

CHAPTER 2: INDEPENDENCE, DEMOCRACY, AND MORALITY ........................19

CHAPTER 3: RESTORING THE PATRIARCHAL ORDER AT HOME AND

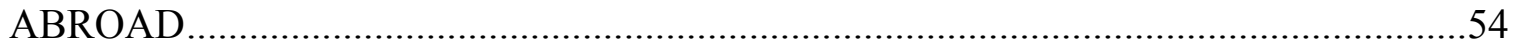

CHAPTER 4: THE PROUD AND SELF-CONFIDENT JAPANESE MAN ..................87

CHAPTER 5: RESTORING THE PROUD AND SELF-CONFIDENT JAPAN...........109

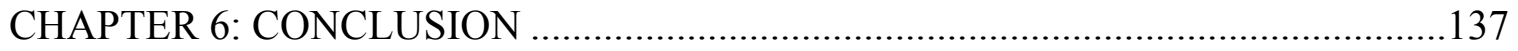

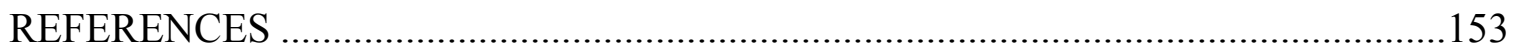

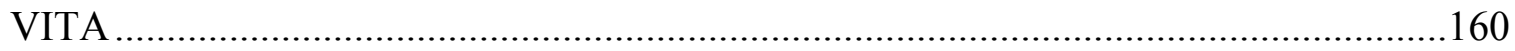


General Agreement on Tariffs and Trade

GATT

Information-Gathering Satellites IGS

International Bank for Reconstruction and Development IBRD

International Monetary Fund $\quad$ IMF

International Relations $\quad$ IR

Japan's Coastal Guard JCG

Korean Peninsula Energy Development Organization KEDO

Liberal Democratic Party $\quad$ LDP

Maritime Self Defense Force MSDF

Ministry of Foreign Affairs of Japan MOFA

Mutual Security Assistance Act $\quad$ MSA

$\begin{array}{ll}\text { Peacekeeping Force } & \text { PKF }\end{array}$

People's Republic of China $\quad$ PRC

Recreation and Amusement Association RAA

$\begin{array}{ll}\text { Republic of Korea } & \text { ROK }\end{array}$

$\begin{array}{ll}\text { San-Francisco Peace Treaty } & \text { SFPT }\end{array}$

Self-Defense Forces $\quad$ SDF

United Nations $\quad$ UN

United Nations Security Council $\quad$ UNSC

Union of Soviet Socialist Republic USSR 


\section{CHAPTER 1:}

\section{INTRODUCTION TO IDENTITY, IDEOLOGY, AND CINEMA}

\section{Introduction}

Japan is not only an important ally of the U.S. but also is the world's third biggest economy, and one of the regional great powers in Asia. Making sense of Japan's foreign and security policies is crucial for the future of peace and stability in Northeast Asia, where the possible sources of conflict, such as territorial disputes or the disputes over Japan's war legacy issues, are recognized. China's increased presence along with its increased economic and military power, as well as North Korea's nuclear weapons issues, are significant security concerns in the region. Accordingly, cooperation among the countries concerned, including Japan, is needed. Japan's policy choices to continue enhancing the mobility and capabilities of its Self-Defense Forces (SDF) since the 1990s have been puzzling, considering Japan usually claimed to be a benign, peace-loving country. The same goes for Japan's unwillingness to continue working on war legacy issues, which eroded its security, as well as political and economic relations with its Asian neighbors.

Japan's behaviors since the end of the Cold War have renewed interest in exploring theoretical approaches to better understand Japan in the field of International Relations (IR). Yet, the puzzles of Japan's foreign and security policies cannot be meaningfully explained by neorealism and neoliberalism, the dominant theoretical approaches in IR that conceptualize the state as a narrowly-defined rational actor that inevitably engages in the struggle for power under anarchy. These approaches have 
typically found Japan to be an empirical anomaly that is not fully rational. Other analyses based on Japan's domestic structures, history, and/or cultures, on the other hand, offer a rich and deep understanding of Japan, but are primarily descriptive.

This dissertation endeavors to explain Japan's foreign and security policies from the perspective of Japan's own imagined sense of national identity or agency, and also through a reflection on "unconscious ideologies." While ideology can be defined as "a ready-made set of meanings and interpretations that can help us to make sense of our world and tell us how to act in relation to our world," an unconscious one is an "ideology that is not formally named and that is therefore difficult to identify. It is the common sense foundation of our world views that is beyond debate" (Weber, 2005, p. 5). Unconscious ideologies influence both the sense of identity and the resultant foreign and security policies.

This dissertation demonstrates that Japan's identities and unconscious ideologies can be explored by analyzing relevant Japanese films. In these films, how the Japan Self should look in its relation to the self, the others, and the world is screened, helping Japan to situate itself within the international community. This dissertation analyzes Japan's foreign and security policies during the early post-occupation era (the late 1940s to the late 1950s), as well as during the "Post-Lost Decade" era (the late 1990s to the mid2000s), and argues that Japan's foreign and security policies can be understood as largely the products of an imagined desirable order, which functioned as ideologies without the Japanese really knowing it. 


\section{Research Purpose and Significance}

This dissertation does not aim to explain the current foreign and security policies of Japan. The overall purpose of this study is to provide a theoretical and analytical framework that will better help to understand the security and foreign policies of Japan. The research performed in this study demonstrates how unconscious ideologies have shaped Japan's foreign and security policies. In so doing, this research will also shed light on an ongoing debate in international relations theory: namely, whether critical security studies can effectively challenge basic assumptions about the anarchy contained within traditional neorealist and neoliberal theories of IR. Thus, unlike neorealist or neoliberal works, this dissertation demonstrates that Japan's foreign and security policies can be well understood without relying on the logic of anarchy that drives states to behave in order to maximize its chance of survival.

This dissertation also contributes to the contemporary debates about Japanese identity by providing a critical analytical explanation of the dynamics at work in Japan's sense of identity, particularly with regard to its foreign and security policies. This dissertation offers a new and different approach to the study of Japan's identity because it emphasizes the idea of unconscious ideology. As such, this study will be an original contribution to IR by examining post-positivist approaches to security and identity, from the standpoint of Japan's own foreign and security policies. This strategy of analysis is something that has not yet been systematically performed in IR. In fact, most research on Japan's foreign policy is descriptive and non-theoretical. The few theoretical studies are dominated by neorealist or neoliberal views. Some post-positivist approaches based on identity or culture have been developed, but they often suffer from poorly developed 
methodologies. ${ }^{1}$ This dissertation will follow a critical path toward analyzing the security studies of Japan that will provide an innovative theoretical, and empirically rich take on the topic.

Traditionally, several explanations had been advanced for Japan's foreign and security policies in relation to Japan's security issues. Japan's adherence to what many scholars have argued as highly regulated and strictly applied policies concerning military affairs, has caught the attention of some scholars since that adherence seems to run counter to mainstream neorealist expectations. Neorealism have typically predicted that sooner or later Japan would fully rearm itself or at least armed itself with nuclear weapons especially after Japan established itself as economic great power (Waltz, 1993). Neorealism can still explain a lot, particularly that Japan's pacifist policies make sense or are necessary in the context of the East Asian power structure. Neorealists typically analyze international security system through the distribution of material capabilities among nations (Buzan \& Waever, 2003). Japan's pacifist policies might be understood structurally as the result of the U.S.-Japan strategic alliance. Lind (2004) argues that Japan's foreign policy behavior can be explained by "a realist strategy of buck-passing" (p. 93). According to her, in order to survive in an anarchical international environment, a state needs to maintain offensive strategies such as becoming a great military power, or it must turn to defensive strategies, such as balancing through alliances, military building, or buck-passing (which means reliance on somebody else's military efforts) (Lind, 2004). This view can explain why Japan has kept its pacifist policies for over 50 years, since

\footnotetext{
${ }^{1}$ For example, Berger (1998) uses many of the public opinions polls. It is not clear if they can explain any observed changes in Japan's foreign and security policies.
} 
1947 when Japan's Constitution was put into effect. Lind (2004) notes, however, that international structure cannot explain why Japan chose the strategy of allying with the U.S. out of other defensive strategies. It also cannot explain why Japan now is suddenly eager to change its constitution, the status of its SDFs, or the use of the military for foreign policy purposes while remains as an ally of the U.S.

Another common argument relies on neoliberal explanations. Katzenstein and Okawara (1993), for example, explain that Japan's adherence to national security policies since the 1950s were the result of its domestic structure. They suggest that considering the rapid transformation from peaceful policies in the 1920s to aggressive ones in the 1930s, it was not only international norms, but also internal governmental structures that made Japan stick to non-aggressive security policies after 1947. They also believed that Japan's governmental structures were constantly attempting to formulate policies that have made it difficult for any government to ever resort to outright military force to solve international problems. Yet, they still do not adequately explain why Japan has made such domestic structures that have limited Japan's foreign and security policy options.

Another frequent explanation for Japan's foreign and security policy behaviors has been that Japan's anti-militaristic culture has forced Japan to stick to its pacifist foreign and security policies (Berger 1993; Berger 1998). In particular, Berger (1993) deploys the notion of anti-militarism, but also questions whether or not Japan might want to remilitarize in the future. He argues, however, that Japan is never likely to again become a great military power due to historical anti-militarism, which prevents a more militaristic foreign and security policy. In a later work, Berger (1996) developed this idea further and provided a revised concept of political military culture that refers to a "larger 
political culture that influences how members of a given society view national security, the military as an institution, and the use of force in international relations" (1996, p. 326). Despite this retooled cultural analysis, Berger believes that the "extreme sensitivity of military security issues" will continue to constrain the course of Japan's foreign policy (1996, p. 355). Similarly, ongoing changes in Japan's security policies and ideas were simply understood as the results of an evolution in Japan's pacifism (Kunihiro 1997; Zhou 2005). Oros (2008) also observes that Japan's security identity consisting of the three principles of "no traditional armed forces, no use of force by Japan except in selfdefense, no Japanese participation in foreign wars," according to his refinement of the definition of Japan's anti-militarism culture, has always been the subject of debate among Japanese elites and the general public (p. 9). He stated that many changes in the attitudes of Japanese elites and general public were found, but the changes of the content of Japan's security identity have not really been observed even in the post-Cold War era.

Each of the arguments introduced above has its strengths; none of them, however, fully solves the puzzles presented by contemporary empirical observations. One of the main problems with all these approaches is that their basic assumptions are about the unchanged nature of Japan's pacifist policies. As Berger (1996) has argued, if Japan's pacifist policies can only survive because of the maintenance of the U.S.-Japan strategic alliance, why has Japan been able to resist U.S. pressures to remilitarize? Similarly, after the 1990s in particular, why has Japan been more cooperative with the U.S. in matters of military security, foreign interventions, and possible rearmament? The domestic structure or culture may explain why Japan cannot be fully remilitarized, but how could Japan then justify sending its SDFs outside its territory, as it started to do in the 1990s? If it is the 
case that the anti-militaristic culture has changed or is fading, why or how has it changed? By emphasizing ongoing changes rather than relying on an assumption about the unchanged nature of Japan's pacifist policies, this study endeavors to provide a more comprehensive and dynamic understanding of Japan's foreign and security policies in terms of identity and ideology.

Related to the previous argument, this dissertation will employ a critical, analytical approach to make sense of changes in Japan's relations with the U.S. and Japan's Northeast Asian neighbors by turning to the concepts of unconscious ideology and identity. In so doing, this dissertation will contribute to the debate on new perspectives in foreign policy analysis. This will be done by relying on David Campbell's Writing Security (1992). In his book, Campbell explored U.S. foreign and security policies over the past two centuries by paying attention to what he called "acts of othering" in the U.S. security discourse. He convincingly argued that U.S. foreign policy over the decades has relied on discursive demarcations between the self and other, friends and enemies, and good versus evil states. Foreign policies themselves have become textual and material acts that create a national self (a U.S. national subject) by identifying and constructing enemies. This approach is very attractive. It is rather awkward to apply such a perspective to Japan, however, because Japan over the past 50 years has really not bee known for its "strategy of othering." Rather, Japan has shown complicated patterns of good and bad relations with the relevant others. For example, Japan-U.S. relations are perceived as good or bad depending on specific contexts. Thus, this study will need to explore the different functions or roles that identity politics play in relation to foreign and 
security policies in order to provide a different critical approach that does not merely copy Campbell's argument, but instead seeks to refine and extend it.

\section{Theoretical Consideration and Definition of Concepts}

In order to make sense of the dynamics of Japan's foreign and security policies, this study will employ a critical analytical approach that relies on the concepts of "ideology" and "identity." These two primary concepts are explored at length in the sections below, where their meanings for this study are clarified.

\section{Ideology}

The notion of ideology was first developed in 1796 by Antoine Destutt De Tracy. According to Eatwell (1999), De Tracy defined ideology as "a science of the human mind" (p. 4). De Tracy had witnessed the brutality of the French government during the "Reign of Terror" period of the French revolution, and he sought to question what enabled such violent acts to be performed in "the name of progress and the people" (Eatwell, p. 9). De Tracy wanted to show what kinds of ideas were misguided based on the violent material consequences they created. To do so, he employed the term "ideology" (with a clearly negative connotation). From that point on, ideology became a common political term. Even Napoleon was known to have used it in his criticism of intellectuals. According to Eatwell, Napoleon referred to it as "an a priori desire to overturn old ways and 'improve' people's lives, and/or to advocate beliefs which suited the interests of proclaiming them" (Eatwell, p. 4). By the 1830s and 1840s, ideology as a concept, had started to play an important role in Marxist thought. Marx himself did not see his thought as ideology, but rather as an idea "based on a scientific understanding of history and inevitable triumph of the working class and socialism" (Eatwell, p. 5). 
However, Engels later modified the meaning of the term to signify "false consciousness." It was as false consciousness that ideology became a central notion in Marxist theory (Eatwell, p. 5).

Although ideology refers to beliefs for mostly political ideas, ideologies are formed in certain ways and seek to fulfill specific social functions. For example, Karl Mannheim states that the concept of 'ideology' reflects the one discovery which emerged from political conflict, namely that ruling groups can in their thinking become so intensively interest-bound to a situation that they are simply no longer able to see certain facts which would undermine their sense of domination. There is implicit in the word 'ideology' the insight that in certain situations the collective unconscious of certain groups obscures the real condition of society both to itself and to others and thereby stabilizes it. (1936, p. 40)

This notion of ideology as an overwhelmingly misleading or distorting belief that serves the interests of powerful groups or classes seems to not be directly applicable or useful for the purpose of this dissertation. Japan's foreign policy and security dynamics particularly with respect to the question on the use of military forces may be explained by suggesting that pacifistic or militaristic foreign and security policy choices are driven by certain ideas. However, these ideas are often considered to serve the interests of Japan as a whole, rather than those of a particular interest group.

Instead of treating ideology as a concept that refers to false consciousness, or misguided beliefs, this study will use ideology more analytically (and not as a critique designed to reject the concept) to refer to a set of ideas meant to realize specific social or 
political functions. For example, Adams (2001) argues that sociologists and other social scientists understand ideology as "a set of political beliefs about how society ought to be and how to improve it, irrespective of whether those ideas are true or false or good or bad" (p. 2). Weber (2005) also notes that ideology is "a ready-made set of meanings and interpretations that can help us to make sense of our world and tell us how to act in relation to our world" (p. 4). More crucially for this study, Weber adds that there are not only conscious or official ideologies such as liberalism or conservatism, but also many unconscious ideologies. Unconscious ideology is a notion that she indirectly borrows from Mannheim, but with a different meaning. For Weber, an unconscious ideology is a nameless, unofficial, but persistent belief structure, one that is difficult to identify and functions in society without people's clear or purposeful knowledge of it. Being an "unconscious" ideology, it is hardly questioned because it is treated as a commonsensical, everyday truth.

Still, ideology's function is to tell us the way things are, but also how they should be. Importantly, Weber (2005) claims that unconscious ideologies are strongly related to culture that can be "understood as 'sense-making,' 'signifying process,' or 'an ensemble of stories, beliefs, and habits" (p. 4). She then writes that, "if culture is a site of meaning production, ideology is a site where meanings that are culturally produced are transformed into just the way things are or the way things ought to be" (p. 6). Thus, revealing the process by which culture (any culture) gets to be transformed into an unconscious ideology is crucial to a critical examination of how ideologies operate, and of what sort of social effects they produce. 
If ideology is a cultural, political, and social site where many meanings become the dominant reality, how should we go about exploring it? A conventional way to investigate the processes by which ideological meanings become constructed and propagated throughout a society or culture (including the sphere of government activities) would be to examine the discourse or language of political intellectuals, as well as politicians, scholars and academics, and public figures. ${ }^{2}$ The discourses or languages of all sorts of individuals and institutions involved in the production of ideology can be traced in governmental documents, academic works, and major newspapers. These texts will be the object of much of the primary archival analysis performed for this project.

However, recent studies (including Weber's) have shown that different cultural sites such as television programs, movies, or popular magazines are also crucial to the production and dissemination of ideological perspectives, particularly unconscious ones. This dissertation targets Japanese popular films throughout time as the sites of investigations, and examine them in order to find unconscious ideologies for the sake of methodological clarity.

Identity

While I believe that unconscious ideologies play a crucial role in the contemporary deployment of Japan's foreign and security policies, identity is another related concept that will be of great importance for this study. Of late, in IR, the concept of identity has been used by several scholars to explain specific security policy choices or

\footnotetext{
${ }^{2}$ Though the concept of ideology is rarely used, many post-positivist analyses of foreign and security policies conduct textual analysis. For example, Hansen (2006) used wide ranges of written texts for her analysis. Samuels (2007) also analyzed various official texts in order to understand Japan's grand strategies. Yet, Samuels' work is descriptive, since there is no clear analytical distinction between the strategy and Japan's foreign and security policies.
} 
decisions. Constructivism in IR can be credited for bringing the notion of identity to the forefront of analytical debates. From the perspective of constructivism, identity, as an idea or ideas about the self, is often seen as a key variable in security policies, particularly to the extent that identity plays a part in the determination of the national interest. In turn, the constructed national interest directly influences the kind of domestic or international identities that international agents or actors formulate. Because of this, as Kowert (2001) suggests, the constructivist approach to identity often ends up leaving us with a tautology: identities shape our interests and interests define our identities.

Although identity can refer to different things, according to Fierke (2007), critical security studies scholars generally agree that "identity exists in a relationship, an idea that is often captured in the concept of alterity" (p. 76). Thus, identity is constructed in relation to an opposition between self and other. Identity often comes to be constructed by way of a play of differences. To develop one's own identity, one has to find, name, and classify different others. Once again, this is why Campbell's work is so important for these purposes. Indeed, Campbell (1992) argues that foreign policy is the practice of making others as enemies, so that the idea of a secure self can be realized. Thus, in the process of making a nation's identity, there always has to be an enemy, or the "other than self." Presented this way identity inevitably implies the presence of specific and strategic discursive practices.

Campbell (1992) states that "America is peculiarly dependent upon representational practices for its being. Arguably more than any other state, the imprecise process of imagination is what constitutes American identity" (p. 105). He goes on to analyze the process of identity construction in and about the United States, and he reveals 
how the strategy of othering works. Fierke (2007) on the other hand, notes that identity can sometimes be constructed without the mobilization of any clear enemy. For example, she believes that a specific European Union identity was shaped without any obvious other. Similarly, Hopf (2002) also argues that the self and other are mutually constitutive. He explains how Russia constructs certain relations with other states based on how Russia understood the self and the other in the domestic discourses. This thesis takes a similar approach, and tries to explain Japan's relations with other states based on Japan's understanding of the self and the other that has been imagined in the popular cultural products but mostly films and literatures.

\section{Research Question}

The research question of this dissertation is as follows:

How did Japan's imagined narratives on the self, others, and the world found in Japan's selected popular cultural products correspond to Japan's foreign and security behaviors in the 1950s and in the 2000s?

\section{Research Strategy and Methods}

\section{Subject of the Study}

This dissertation presents case studies of Japan's foreign and security policies in two different time periods. The first time period is from the late 1940s to the late 1950s, which I will refer to as the early post-occupation era. Japan unconditionally surrendered to the U.S.-led allied forces in 1945 , and was governed by the occupation authority until Japan regained its sovereignty in 1952. During that time, Japan made various important foreign and security policy decisions. As a country whose sovereignty had only recently been restored, Japan joined the liberal democratic camp, and concluded an exclusive 
security treaty with the U.S. Japan also reestablished its relations with other great powers, officially with the Soviet Union, and informally with China. Japan failed to normalize relations with South Korea during this period, but managed to do so with Burma and the Philippines.

The second time period is from the end of the 1990s to the mid-2000s, which I call the Post-Lost Decade. During this time period, Japan experienced a prolonged recession after the collapse of the bubble economy. Japan again made various important foreign and security decisions, including supporting and playing proactive roles in the U.S.-led "War on Terror" and U.S.' invasion of Iraq. Japan continued to foster close relations with the U.S., and for a time developed amicable relations with South Korea. At the same time, Japan's relations with North Korea deteriorated to the extent that Japan's humanitarian assistance to North Korea and even the interactions between Japan and North Korea at non-governmental levels were severely criticized by the Japanese public.

These two time periods were chosen strategically for three reasons: First, they are separated sufficiently, and international circumstances are sufficiently different, that one might expect to see some variation in Japan's sense of self and in the sorts of identityideologies it embraces. Second, Japan had actively discussed its new identities during the periods selected, and as a result has made a textual analysis of the official documents possible. Third, Japanese films were widely consumed, so the materials to explore the unconscious ideologies were available. Indeed, the Japanese film industry experienced a significant decline after the 1950s. From the late 1990s, the Japanese films started being widely consumed by the Japanese again. Thus, it is possible to assume that among 
various cultural products, if the Japanese films indeed manifest Japan's worldviews, such worldviews would be considerably clearer in the 1950s and 2000s.

\section{Materials}

In order to analyze Japan's foreign and security policies, I first explore Japan's identities and unconscious ideologies. This approach is inspired by the work of Cynthia Weber, particularly her analysis in "Imagining America at War" (2006). Weber convincingly argues that the Hollywood blockbuster movies she calls the "post-9/11 films"- such as Pearl Harbor (2001), We Were Soldiers (2002), Behind Enemy Lines (2001), The Quiet American (2002), Black Hawk Down (2001), Kandahar (2001), Collateral Damage (2004), In the Bedroom (2001), Minority Report (2002), and Fahrenheit 9/11 (2004) — are public sites where the moral narrative of Americans was narrated. Narratives about good/bad or just/unjust Americans in the movies function as metanarratives that help to understand the official stories about U.S. foreign policy, especially after 9/11. At the same time, Weber notes that movies such as The Quiet American, Kandahar, In the Bedroom, and Fahrenheit 9/11 also challenge the image of a moral America and the popular tendency to shape the narrative positively for U.S. foreign policies. Weber's work suggests that the narratives about morality in the movies can explain how specific foreign policies can be accepted or refused, or at least make sense of specific foreign policies.

This study first examines various official discourses on Japan's identity. This is accomplished through an analysis of official government documents, but mainly through the Prime Minister's inauguration speeches, the various documents he has produced, and other documents by different special committees formulated by the Japanese government. 
The study then analyzed the selected films, investigating the extent to which they correspond to the questions being asked in the official discourses. From the late 1940s to the mid-1950s, the selected films included those of internationally and domestically acclaimed directors, including Kurosawa Akira, Mizoguchi Kenji, and Ozu Yasujirō. ${ }^{3}$ They were chosen because of their relevance to questions about Japan's identities and unconscious ideologies. The lists of the films used for the study are as follows: Women of the Night [Yamino Onnatachi] (1948), The Life of Oharu [Saikaku Ichidaionna] (1952), The Street of Shame [Akasenchitai in Japanese or Red-light district] (1956), Munekata Sisters [Munekata Shimai] (1950), Late Spring [Banshun] (1949), Early Summer [Bakushū] (1951), Early Spring [Sōshun] (1956), Tokyo Twilight [Tōkyō Boshoku] (1957), Ugetsu [Ugetsu Monogatari or Tale of Ugetsu] (1953), Seven Samurai [Hichinin no Samurai] (1954), Sanshō the Bailliff [Sanshōdaū] (1954), Godzilla [Gojira] (1953), Godzilla Raids Again [Gojira no Gyakushū] (1955), Hidden Fortress [Kakushitoride no Sanakunin] (1958), To Live [Ikiru] (1952), and Tokyo Story [Tokyo Monogatari] (1953). Each film tells a different story about different agents and how these agents interact with each other. Read together, however, they show how the world is imagined in the eyes of Japan. In addition to these films, the Japanese best-selling novels including Makioka Sisters [Sasameyuki or Light Snow] (1948) by Tanizaki Junichirō, and Home Coming [Kikyō] (1948) by Osaragi Jirō were used because the actual films produced and screened in the 1950s based on these novels were not available.

\footnotetext{
${ }^{3}$ This dissertation uses the conventions for Japanese names. The family names are followed by the given names.
} 
From the end of the 1990s to the mid-2000s, the study analyzed Japanese blockbuster movies, as it was difficult to find films that are held in the same regard as those selected from the 1940s and 1950s, when Japan enjoyed a so-called golden age of Japanese films. These Japanese blockbuster movies are relevant because of the popularity of them among the Japanese people at the time. This approach is inherently experimental. The methodological problems that stem from these different kinds of films will be revisited in the conclusion. The films selected from this period are: Bayside Shake Down [Odoru Daisōsasen or Dancing Police] (1998), Bayside Shakedown 2 [Odoru Daisōsasen 2] (2003), Umizaru [Umizaru or Sea Monkey] (2004), Whiteout [Howaitoauto] (2000), Aegis [Bōkoku no Aegis] (2005), Japan Sink [Nihon Chinbotsu] (2007), Limit of Love: Umizaru [Limit of Love: Umizaru] (2006), All About Lily Chu-Chu [Lily Chu-Chu no Subete] (2001), Battle Royale [Batoru Rowaiyaru] (2000), Go [Gō] (2001), Spirited Away [Sen to Chihiro no Kamikakushi] (2001), Evangelion [Ebangerion] (2007), Howl's Moving Castle [Hawl no Ugoku Shiro] (2004), Be With You [Ima Aini Ikimasu] (2004), Always: Sunset on Third Street [Ōruweizu: San-chōme no Yūhi] (2005), and Always 2: Sunset on Third Street [Ōruweizu: San-chōme no Yūhi 2] (2007), Yamato [Otokotachi no Yamato] (2005), Lorelei [Lōrerai] (2005), and For Those We Love [Ore wa, Kimi no Tame nikoso Shini ni Iku] (2007). Corresponding documents explaining Japan's foreign and security policies in this period included various official government policy documents, Diet Records, and other secondary materials.

\section{Organization of the Dissertation}

The remaining sections of this dissertation are organized as follows. In Chapter 2, selected Japanese popular films from the end of the 1940s to the mid-1950s are analyzed 
for Japan's unconscious ideologies. Chapter 3 contains an analysis of Japan's foreign and security policies based on the unconscious ideologies found in Chapter 2. Chapter 4 examines popular blockbuster films from the end of the 1990s to the mid-2000s. Chapter 5 again explores links between unconscious ideologies and Japan's relations with the U.S., South Korea, and North Korea in the 2000s. Lastly, Chapter 6 summarizes findings from the analyses and discusses the efficacy and limitations of the use of the concepts of identity and ideology for the analysis of foreign and security policies. 


\section{CHAPTER 2:}

\section{INDEPENDENCE, DEMOCRACY, AND MORALITY}

\section{Introduction}

In this chapter, the identity and unconscious ideologies of Japan from the late 1940s to the mid-1950s will be explored. This period is often called "the Post-War Restoration Era [Sengo Fukkouki]." The restoration's end is signified by the popular phrase "it is no longer the postwar period [mohaya sengodewa nai]" that was used in the 1956 Economic White Paper (Japan Economic Planning Agency, 1956). Japan celebrated a recovered economy that achieved the same level of prosperity that they had during the pre-war period, as well as the admission to the United Nations (UN).

Accepting the Potsdam Declaration and its series of occupational policies meant that becoming a liberal democratic and peaceful nation state was understood in Japan as condition for regaining sovereign independence. Given this goal to construct a new Japan that was no longer belligerent or undemocratic, discussions about the identity of Japan and the Japanese were ubiquitous in Japanese society. The identities of the self, the meanings of Japan as a defeated country, occupied Japan, and independent Japan were crucial to Japan's successful interaction with other states. The answers to questions about Japan's identity - who were they, who are they, and who do they wish to be-are explored in this chapter by examining popular films screened in early post-World War II Japan. These films showed not only what it means to be a defeated Japan and an occupied Japan, but also how a liberal, democratic, and independent Japan could achieve its new status. These identities are presented through the narratives of struggles of the Japanese women and men. Read together, Japan's subjectivity as the liberal, democratic, peaceful, 
and moral Japanese patriarch whose understanding of the self, the others, and the world is revealed. These culturally produced and consumed meanings will have the anticipated function as unconscious ideologies for Japanese foreign and security policies.

\section{From the Defeated to the Occupied to the Again Independent}

In the late $1940 \mathrm{~s}$, Japan still had not yet regained sovereign status, was still economically struggling, and had signs of social unrest everywhere. Japan initially envisioned coming to terms gracefully with its fall from the status of great power and then solemnly establishing itself as "small but beautiful [Chisakutemo Utukushii]" as Dazai Osamu (1946), a Japanese novelist sentimentally suggested. Such a Japan, however, had not been realized.

Japanese elites were frustrated and started identifying the problems that delayed movement not only toward sovereignty, but also toward Japan's spiritual independence [Shutaisei]. The declaration by the Liberal Democratic Party (LDP), which was newly established in 1955, and went on to serve as the ruling party until the early 1990s, succinctly expressed Japanese officials' understanding of Japanese society at that time. According to the LDP, Japan's problems were as follows: 1) The lost patriotism and the sense of sovereignty; 2) the chaotic political situation; 3) the failure to realize economic independence; 4) the instability of people's livelihoods; 5) the failure to prepare for political independence; and 6) the presence of widespread class conflict (LDP, 1955). The effects of early occupation policies were often cited as the causes of these problems. Other critics blamed the changes of U.S. policy toward Japan-the so-called "reverse course"- that began in the later 1940s. Both groups worried about the identities of Japan and the Japanese after interventions by the occupation authorities. Japanese officials 
discussed who the Japanese had become, and then who the Japanese should desire to be. This chapter will explore the answers to such questions in the selected films, focusing especially on the fall and rise of women and men.

\section{Fallen Women in the Official Discourses}

Representations of fallen women were important, and were significantly transformed, in occupied and post-occupation Japan. The fall and rise of these women clearly were allegorical to Japan's recovery from the defeat and the occupation. The most common form of corruption discussed by Japanese officials and intellectuals was the existence of female prostitutes called "Pan-pan," "Pan-pan Girl," "Women of the darkness [Yamino Onna]," or "Special Lady [Tokushu Fujin]." These women were understood to represent a Japan that had lost its independence. For example, Mutō Unjuro, a Japanese politician, wrote:

Up to the Occupation by the American armed forces, we had no such word as 'Pan-pan' in the Japanese language. Of course we had prostitutes, but certainly never in our history have we seen such large-scale, brazen, and shameless traffic in female prostitution. It is a national disgrace, indeed! ... I believe the first step of Japanese independence should be to clean up the 'Pan-pan' in all corners of our country. (Mutō, 1953, p. 29)

In the same volume, Ishigaki Ayako further confirmed that "Pan-pan" indeed showed who the Japanese were, including men and women at that time. She wrote:

Both men and woman in Japan lost the idea of chastity. It is not only the 'PanPans' on the street who lost chastity, but we all lost the sense of integrity in protecting something within us that is clean and just...We lost our backbone, 
became servile, and kowtowed. We have lost the spirit of independence. (Ishigaki, 1953, p. 30)

Yet in 1945, right after Japan's surrender, the prostitutes were in a way the saviors of Japan. This was particularly true of the Japanese female sex workers who served American soldiers while working at the Recreation and Amusement Association (RAA), run by the Japanese government. These women were considered to be the loyal servants of Japan, sacrificed to protect the purity of Japanese blood (Dower, 1999). Sakaguchi (1947) also wrote that the street prostitutes were liberalized, happily individualistic, and strong. According to him, the street prostitutes were not that much different from other ordinary people, though bereft of intelligence. He even suggested that when these people would regain intelligence, Japan would become a true cultural nation.

In contrast, the U.S. authorities ordered public prostitution prohibited, saying that such practice was not only undemocratic, but also a violation of women's rights (Dower, 1999). Instead of following the order in a straightforward manner, the Japanese government prepared a loophole to protect the industry. The argument of "necessary evil" parallels the finding that prostitution helped Japan obtain foreign currency. Oguma (2002) provides an excerpt from the "Contemporary History of Japan [Gendai Nihon no Rekishi]" published in 1953, in which Japan's economy was referred to as the "Pan-pan Economy" partially because prostitution was such a major source of foreign currency acquisition (Oguma, 2002, p. 277).

Negative ideas about street prostitutes were further disseminated by the Japanese elites. Fukuda Masako, a female member of the lower house and socialist party, provided the narratives on pan-pan girls based on her onsite research at the hospitals that housed 
the prostitutes. She insisted that the prostitutes were liars who needed to learn the spirit of working hard. She even suggested that the proposal to improve the treatment of prostitutes were too generous, and that the government should provide food and a stipend in exchange for making them work. Any female organizing of the freelance prostitutes on the street was considered to be a significant evil, second only to freelance prostitution itself. Some policy makers were also disturbed by the fact that some successful street prostitutes could make twice to three times more in a day than the average monthly income of a typical Japanese worker.

In 1955, the Ministry of Health, Labor and Welfare provided its own narrative on the identities of the prostitutes. According to its White Paper, the majority of the prostitutes were women with normal powers of reason who ended up turning to prostitution due to economic hardship. The White Paper also emphasized that the majority of the prostitutes supported their own children and/or their younger siblings. Its proposed solutions to "save" these prostitutes were listed as: 1) going home; 2) obtaining new jobs; and 3) marriage (Minister of Health, Labor and Welfare, 1956). The idea was that the sex workers could be rehabilitated and rescued by the Japanese government.

Japan struggled with the meaning of democracy and liberalism through its discussions of prostitutes. If Japan was to become a democratic country, then prostitution must be banned and eradicated. But at the same time, Japan must also become a liberal country that respects the rights of all people, including the rights of sex workers. If prostitution is a means of survival, and individuals have the right to life, how should liberal authorities respond to it? What if those women do these acts simply because they want to? This matter becomes further complicated because the presence of the "Pan-pan" 
are strongly associated with the meanings of the occupation. If being occupied means sleeping with the occupier, what should Japan do about it in order to restore its true independence? How should Japan respond to the issue of prostitution if it becomes an answer to the question of how democratic liberal Japan should interact with its other - the occupied? These preoccupations are reflected in the popular films of the era, as we see below.

\section{Cultural Responses}

\section{Fallen Women}

The film Women of the Night (1948), directed by Mizoguchi Kenji, powerfully defines sex workers as women who wrongly liberated themselves to become bad, independent persons. Sex workers were portrayed as textbook examples of the byproduct of the early occupational policies that promoted liberation and empowerment of the women, but merely produced selfish and amoral Japanese. Women of the Night shows one facet of Japan's occupation identity. The life of Fusako, the protagonist who becomes a fallen woman, is allegorical to Japan's transformation after the defeat in 1945.

In the beginning, Fusako is a poor, humble and caring mother. When she is encouraged to practice prostitution to save her sick baby, she refused to do so. She was still a good Japanese woman. A few days later, however, her baby dies and she also learns that her husband was killed in the war. After having lost her husband and bay, her husband's family is no longer willing to support her, and she is left to fend for herself. In desperation, Fusako becomes the lover of the president of a company in which she is employed as a secretary. She is given a small apartment by her lover and lives a peaceful life for a while. Fusako's fall, however, does not end there. 
Fusako's life is once again changed when she finds out that her sister, Natsuko is sleeping with her lover. Outraged, Fusako leaves the apartment. When Natsuko finds Fusako again, the latter has become a sex worker with heavy makeup and western clothing. Her attire visually confirms that she no longer is a humble and good Japanese woman in a traditional kimono. Fusako has become mean and angry. Natsuko asks Fusako to come home with her, but Fusako outright refuses. The point here is that Fusako had a chance to quite prostitution, but she was too emotional to do so. Fusako also knew that she could go to a government-owned rehabilitation center to prepare herself to for a different life, but refuses that help as well.

Neither her sister, nor the authorities, could rescue Fusako. Thus, this film denies intervention can resolve the prostitution issue. Instead, Fusako eventually changes her mind through her interaction with her "lesser other," her sister-in-law, Kumiko. Kumiko was a humble factory worker, but is fooled by a young delinquent student who rapes her, takes her all of her money, and then tells her to get lost. With nothing left, she has no choice but to start looking for her first prostitution customer. Fusako finds Kumiko, and tells her to go home. Kumiko tells her that she will enjoy becoming a sex worker. Outraged, Fusako kicks and yells at her:

[Fusako]Wallow in this mud little smart alec! Get sick, go blind. You fool. Have your nose rot away from syphilis. Watch yourself rot inside out. Then have a monstrous freak of a baby! Ruin all the men in Japan, and all the women - every last human being! (Mizoguchi, Women of the Night, 1948)

Kumiko changes her mind, and Fusako tries to leave for her home with her, but other sex workers beat Fusako as a ritual punishment for leaving the group. Suddenly though, the 
other sex workers decide to stop the violence, saying that they wish to see a better world in which fewer women will be like them. This is the moment when Fusako successfully leaves her identity as a street prostitute. She could do so only by rescuing Kumiko, but her act also led other prostitutes to think that what they are doing is wrong and to support Fusako's decision to leave prostitution. The film ends as Fusako and Kumiko go home.

Women of the Night suggests that becoming a sex worker is ultimately a matter of choice. Yet, Fusako no longer could defend her choice, because what she was doing could encourage others, especially younger generations, to do exactly the same as Kumiko tried to do. In contrast, The Life of Oharu (1952) highlights a different social context of prostitution and prostitutes and conveys the message that prostitutes are the product of a society in which men control women.

In The Life of Oharu, Oharu lives in the Edo Era, when Japan was isolated and finally free of civil war. The story is based on the popular novel The Life of an Amorous Woman [Kōshoku Ichidai Onna], written by Ihara Saikaku in 1686. Anderson and Richie (1959) describe it as "a realistic and picaresque account of the downfall of a willing courtesan" (p. 49). It is clear that Oharu is a prostitute by choice in the novel because at one point in her life, she masters tailoring and is able to support herself fully by running a tailoring business, but she chose a life as a sex worker.

In the film, director Mizoguchi instead made Oharu a tragic heroine at the mercy of fortune. Oharu is a victim of patriarchy. Her life depends on which kinds of man she bonds with. When she is with her husband she lives a happy life. When she is with her father, who struggles financially, she is sold to a brothel. When she does not have a patron, she lives as a miserable street prostitute. The film continuously links the ups and 
downs of Oharu's life to the man she is with, irrespective of her changing irrespective of her changing attributes such as her class, her look, her experiences, her desires, or where she lives. Indeed, if she wanted to free herself, she would have to give up her identity as a woman. In the end, she becomes a monk and recovers her sense of peacefulness. What the film conveys is that in a male-dominated society, some women have to endure the kind of life that Oharu did, and that is a tragedy that viewers must come to terms with.

The Life of Oharu suggests that prostitution is the product of women's subordinate status to men, and giving up female identity maybe a solution. Another of Mizoguchi's prostitute films, The Street of Shame (1956), suggests that the economic independence for women could be a partial solution. The story takes place at a brothel called "land of dreams [Yume no sato]" in the 1950s. In the film, each sex workers has a different story of becoming a prostitute: one has a baby and sick husband; another is uneducated, from a poor rural area, and needed money to raise her son; and another left an abusive husband, but was unable to find alternative job. Mickey is a newcomer who dresses herself in colorful Western clothing and likes to spend more money than she makes. She came up with her American name "Mickey" when she had an American patron. She refuses to use the Japanese name given to her by her parents. Later, viewers learn that Mickey is disgusted with life due to her disappointment in her father, who never took good care of her mother.

The Street of Shame diversifies the images of the prostitutes by displaying different types of prostitutes. Yasue, for example, is a very smart business-minded woman. She is a young, beautiful top-earner in the brothel, and she not only saves her money (unlike Mickey) but also earns extra income by lending money to her fellow 
prostitutes. Yasue also makes a false promise to marry one of her clients, a young owner of a futon store, to get more money from him. The young owner steals money from his store to support Yasue, and the store eventually goes bankrupt. Yasue abandons him, pays off the debt, and buys the futon store to start a new life.

Yet, other than the fact that Yasue is no longer a prostitute, everything else remains the same. She knows well the struggles of her former colleagues, there is not even a hint that Yasue would try to rescue them. Instead, Yasue comes back to the brothel to sell futons to her former boss and still offers to loan money to her former fellow workers to make extra profits. Yasue never challenges the social order of the period-the dominance of males and the subordination of females. At the same time, the film suggests that there exists a status differences among the women. For example, if a woman is smart like Yasue, she can improve her position in life. She is still subordinate to men in general, yet her improved position contrasts with that of inferior women, prostitutes. According to the film, the prostitutes - as the occupied — can partially recover from their life of subordination by seeking economic independence. Even so, Yasue is not a proud solution to the problems of subordination. Her success was possible because she could exploit a weak man, and even weaker women, and perhaps only because of the unusual opportunity to buy the futon store. Such nuanced understanding of women's economic independence confirms Japan's understanding of a kind of liberalism by which the U.S.led occupation authorities encouraged empowerment of women. In this context, it makes more sense that the successful Yasue would not even try to bond with her colleagues and together to improve the status of women. If Japan's liberalism is expressed through women's empowerment, it has to be very carefully administered. 


\section{Independent Women}

Indeed, if we consider cultural products other than films, women who aspire to or actually achieve economic independence are in general represented as morally corrupt, especially when their action challenges male dominance. For example, the novel Makioka Sisters (1948) conveys such moral of story. This best-selling novel in the 1950s, written by Tanizaki Junichirō is a mix of stories about the declining fortunes of the Makioka family. The novel focuses on the family's four sisters, and especially the two single women in the family, Yukiko and Taeko. The recovery of the Makioka family depends on the successful marriages of Yukiko and Taeko.

While Yukiko is on a journey to find her husband, Taeko shows interest in becoming a working woman. Taeko once tries to elope with her boyfriend, which becomes a scandal, stigmatizing her as an improper woman. The best way to save her reputation is to marry her boyfriend when the time comes, but her boyfriend does not seem to be able to financially provide for her. Taeko had already been good at making dolls and made a modest income doing it, so she told her sisters that she wanted to go to Europe to study becoming a seamstress in a bid to support her family in the future. Unable to obtain financial support from her family, Taeko gives up on going to Europe to study tailoring, but starts living in a small apartment by herself, and continues going to a sewing school in Japan without telling the head of their family.

As the story develops, the Makioka family finds out that Taeko was not as financially independent as she claimed, and that her prodigal boyfriend was in fact helping her. Taeko leaves her prodigal boyfriend, who no longer can support her financially, and starts dating a man who is from a poor family. The Makioka family does 
not approve, but his sudden death solves the problem. Still Taeko continues to live following her heart, and has a baby with an undesirable man-a bartender. Her family orders Takeko to hide herself until she delivers the baby so that her unmarried sister, Yukiko, still can marry someone proper who is suitable for the Makioka Family. The apparent moral of the story is that Taeko wished to be an independent woman who can make her own choices, but only brought trouble to the failing Makioka family. On the other hand, Yukiko, who was willing to choose her husband out of the candidates already approved by the Makioka family, was morally right in this story.

Such morality tales are visible not only in classic novels like the Makioka Sisters but also in other best-selling novels at that time, such as Osaragi Jirō's Home Coming (1948). Osaragi's story is mainly about the strange interactions between the two protagonists, Kyōgo and Saeko. Saeko is an independent woman, but is also an inappropriate figure. Saeko's husband is from a noble family, fallen onto hard times. Saeko escapes her duties as a wife by hiring her husband's mistress as a housemaid. She then moves to South Asia and successfully runs a fancy Japanese restaurant that caters to mainly to high-ranking Japanese officials. Saeko also was a smart woman. She anticipated the defeat of Japan, so she purchased many diamonds and made a fortune selling them after the war.

Saeko exercises her freedom by breaking the moral code of a married woman and committing adultery. She has a one-night affair with Kyōgo, a former high-ranking military officer who had to exile himself due to his involvement in embezzlement. She then got him sent to jail by reporting him as a spy to a local military officer, but no clear reason is revealed in the novel. 
After World War II, Saeko goes home to Japan and finds out that Kyōgo has managed to return as well. Facing two men, her husband and her lover, Saeko confronted a dilemma. Begged by her husband not to leave him, Saeko tells her husband "I feel like I am much manlier than you here" (Osaragi, 1948, p. 224). Seeking reconciliation with her one-night lover, Kyōgo also did not solve the problem of her identity crisis. Kyōgo tells Saeko that she is not a typical Japanese woman. She is remarkably clever, unsentimental, and stronger than Kyōgo, a man. Saeko then seduces Kyōgo, thus trying to make Kyōgo feel better by letting him conquer and subordinate her. Instead, Kyōgo compromises her independence and freedom by stripping her of her fortune not by force, but through a manipulative wager. The message here is clear. Economically independent women who are not subordinate to men are dangerous. A superior male cannot correct her through violence, but can do so by his intelligence.

If a woman seeking her independence is judged immoral, what can a woman in trouble do? In the film Munekata Sisters (1950), Setsuko is forced to strive for financial independence in light of her unemployed husband. Setsuko is a proper Japanese woman who loves traditional elements of Japanese beauty, such as ancient temples and refined kimono. Out of necessity, Setsuko starts working at a bar with her friend. Eventually her old boyfriend offers to help her start a new business. Her husband, meanwhile, found a new job, but then suddenly died. With her husband gone, Setsuko has the freedom to be with her old boyfriend. She recognizes her desire to do so, but she decides not to. This is in part because of a sense of guilt she has over her husband, who died before getting over his disappointment about Japan's defeat in the war, although how he felt about the defeat is not her fault at all. In the film, Setsuko even has a smile of satisfaction and confidence 
when telling her decision to her young sister. Setsuko has to live with her sense of regret for her husband, and most likely faces financial problems after refusing her old boyfriend's offer of new business opportunity. Yet, Setsuko's choice is generally seen as morally right since she gives her priority to her husband's honor rather than to her own feelings and financial success.

The women who try to survive by their own efforts in these works are mostly presented as prostitutes, as discussed above. If not, they are more or less portrayed as femme fatales; Saeko and Yasumi are very typical of this, as is Taeko in Makioka Sisters. In the words of Sachiko, the older sister of Taeko, the sickened color of Taeko's dull and flabby skin looked as if it were hiding venereal disease, a fact that reminded her of the skin of the class of fallen women (Tanizaki, 1948, p. 756). For the case of Setsuko in Munekata Sisters, however, a solution is given: Setsuko could avoid becoming a femme fatale by remaining faithful to her husband who just passed away. As stated above, the concept of women who try to work and be wealthy enough to support themselves is very problematic within Japanese cultural products such as these.

\section{Proud but Dependent Women}

So far, the Japanese movies and novels examined here suggest that Japan could regain its independence through economic recovery. At the same time, such recovery should not threaten the male-dominated social order. If so, achieving one's improvement of economic status through marriage is indeed a morally right solution.

Late Spring (1949) conveys such a message. It is the most optimistic story of a father's efforts to arrange a marriage for his daughter. Satō (1982) describes Late Spring 
as "a masterpiece on the peaceful life of a middle-class family that makes audiences feel for the first time that peace has finally come to Japan" (p. 256).

In the film, Noriko is the beautiful and caring daughter of Shūkichi, a widower and a university professor. Noriko is twenty-seven, and Shūkichi worries that she might miss the opportunity to find a good husband out of a sense of duty to him. He lies and says that he plans to remarry so that Noriko, in turn, will also agree to her own arranged marriage. Shūkichi lectures Noriko that marriage may not be great in the beginning, but a happy marriage is something she would have to build. On the other hand, Noriko just apologizes and says that she has been "selfish," suggesting that she is willing to do what is good for her father. The moral of the story here is that doing the right thing does not depend on what each individual prefers to do.

If marriage is not the preferred choice of father or daughter, what makes that choice morally right? Another of Ozu's film, Early Summer (1951), provides an answer: the absence of a strong patriarch contributes to the dissolution of the family. Therefore, what the patriarch thinks is right must be given priority over what the other family members think is right or good. This film is familiar: "again the setting was Kamakura and again the subject was marriage and the resultant breaking of home" (Anderson \& Richie, 1993, p. 197). In this film, the traditional patriarch is too old to tell Noriko what to do. The older brother tries to take that role, but he is already a weakened patriarch. His efforts to arrange a marriage for his younger sister fail, and Noriko decides to select her husband by herself. Her older brother and parents are unhappy with her choice, and Noriko eventually moves far away with her husband-to-be. Her parents decide to move back to the countryside, while her older brother and his family remain in Tokyo. Noriko's 
decision thus brings the dissolution of her family, making this a morality play about selfishness.

As the father in Late Spring suggested, even though marriage is the right thing to do, married life is not easy to maintain. In Early Spring (1956) as well as Tokyo Twilight (1957), wives decide to stay with their husbands despite the latter's immoral behaviors. Early Spring depicts the weariness of married life for the middle class salaryman Shōji and his wife Masako. Shōji's life may be boring but also seemingly normal: he drinks with his colleagues after work, joins a small trip with friends, and enjoys a reunion with his war buddies. A female colleague approaches him and he starts having an affair. After Masako finds out about the affair and leaves him, her mother, her friend, and her neighbor all tell Masako that their husbands cheated on them at sometime in the past. According to Masako's mother, men just cheat. There is not much that women can do about it. As Masako also confirms such a "universal truth," Masako forgives her husband. When they are reunited, Shōji apologizes and Masako just says, "It was partly my fault too" (Ozu, Early Spring, 1956). Masako does not demand anything of him, and they promise to start a new life together.

Masako and Shōji married for love and their relationship is based on mutual love and respect, thus healthy and equal. Such a relationship is, however, contradictory to the male-dominated social order. This disturbed disorder must be recovered and a solution is provided in this film by confirming the subordination of the women to men. In that sense, an act of accepting and forgiving a cheating husband is natural and even virtuous. Why? An extramarital affair is an act of displaying a man's power over other men. A wife's acceptance and forgiveness of such an act then confirms not only her husband's 
superiority to other men, but also his superiority to women - including his wife whom he loves.

Surely, such a process of recovering order does not always have to be involved in an extramarital affair. In the later Ozu film Tokyo Twilight, another father wonders whether marriage was a good solution to secure his daughter's life. His daughter Takako is married to Numata. Her father approved of the marriage, but Takako returned to his home, complaining about her marriage. Meanwhile, his other daughter Akiko is still young, single and, it turns out, pregnant. She has an abortion and, later, is killed by a train. Perhaps marriage does not always improve a woman's life, but the alternative seems in this film to be worse. In the end, Takako tells her father that she has decided to maintain her marriage for the sake of her child. Both the father and daughter know that they do not feel good about it. Still Takako's father concludes he must support her decision.

\section{The Peasants in Official Discourses}

Like prostitutes, peasants served as another symbol of a subjugated but democratic and moral Japan. On December 1945, the occupational authorities implicitly acknowledged their importance by ordering a series of agricultural reforms, stating:

The Imperial Japanese Government shall remove economic obstacles to the revival and strengthening of democratic tendencies, establish respect for the dignity of man, and destroy the economic bondage which has enslaved Japanese firmer to centuries of feudal oppression. The Japanese Imperial Government is directed to take measures to ensure that those who till the soil of Japan shall have amore equal opportunity to enjoy the fruit of their labor (De Bary, 2005, p.1043). 
Thus, the peants were also seen as victims of the old, traditional order from which they must be rescued in order to make a democratic Japan possible. The Japanese policy makers followed the order, and the land reforms were completed by 1948 .

Upon declaring war against the United States and Great Britain in 1941, the Japanese were "loyal and brave subjects" of the "Emperor of Japan, seated on the throne of a line unbroken for ages eternal" (Imperial Rescript, 1941). The Japanese were to "faithfully and diligently" carry out the war in order to ensure their country's independence, as well as the stability of East Asia (Imperial Rescript, 1941). In 1945, the Emperor still referred to the Japanese people as his subjects and "good and loyal." But soon, such a right-minded quality of the Japanese people was put into question. Why had the good and loyal Japanese ended up becoming a defeated nation? The first Prime Minister during the occupation, Higashikuninomiya Naruhiko, even urged the Japanese people to take the blame and express regret for the defeat.

The elites who were critical of labor movement and public strikes often labeled such activities as unpatriotic and undesirable for Japan and the Japanese. Prime Minister Yoshida deemed participants in labor movements "lawbreakers," though he later had to retract this remark. The way Japanese officials and intellectuals saw peasants was ambiguous at best. Losing the rice supply from Japan's former colonies resulted in an acute food shortage that required the government to demand more than peasant rice growers could possibly manage. Yet, the peasants who did not cooperate with the delivery request of rice and grain were called "evil peasants [Akunō]." Evil peasants were egoistic and only cared about their own interest. Many intellectuals - especially those with an 
urban background - expressed negative views of the peasants. For example, Sakaguchi Ango stated that:

It is said that the essence of the culture is the progress, but then there is no such a thing like progress in agricultural villages. What they have is the distrust and the suspicion toward the others and tenaciously developed skills of calculating the loss and gain. The agricultural villages are often described as simple and honest, but such understandings were untrue from the beginning. (Sakaguchi, 1946)

Sakaguchi further argued that the peasants always betray their neighbors and best friends in pursuit of their own gains. Peasants do not try to improve anything, and are only good at managing situations in very dubious ways. This hatred of the peasants was strongly related to the intellectuals' struggle for food during and even after the war. Hatano Isoko, a female psychologist, wrote that she felt upset when she had to bow and scrape to peasants who behaved arrogantly just so that they would sell her food (Hatano, 1951, p. 77). Even after Japan's defeat, peasants were not enthusiastic about helping with the food shortage, which further made the city dwellers unhappy.

Maruyama Masao further commented that the reported wrongdoings by the Imperial Armies were carried out by the people who originally came from the lower class and belonged to the lower class within the Imperial Army. Oguma (2002) suggests, however, that hatred of peasants may have also come from pressures on intellectuals to behave like peasants during the war in order to survive. Facing pressure from the government, many intellectuals had to cooperate with Imperial Japan against their will or else they had to give up their own friends. 
In the end, the peasants as a representative of a democratic Japan is mostly associated with yet unrecovered Japanese patriotic and peaceful identities. Through peasant narratives, Japan sought to come terms with the past wrongdoings, how to move forward, but also to respond to threats differently.

\section{Japanese Sons in Crisis}

In the films of the 1950s, class struggles are not as visible as much as they could have been considering the social contexts of that moment. During the 1950s, around 50\% of the Japanese engaged in agricultural, forestry, or fishery business. In 1960, around $30 \%$ of the working population was engaged in the agricultural, forestry, and fishery business, and about $30 \%$ of the working population was engaged in manufacturing. Thus, a third the population could identify with the peasantry, while another third would be able to identify with factory workers.

From period films to contemporary films, the proletariat/lower class and the bourgeois/upper class are rarely represented, especially in the 1950s. Yet, peasants can always be seen in period films, reminding the viewer of textbook knowledge about Japan's four class hierarchical structure (the samurai as the ruling class, and the peasants, artisans, and merchants as the commoners who are ruled). Below these ruled were outcastes that are discriminated against and invisible in popular cultural products. Thus, the cultural products in the 1950s were mostly concerned with producing relations within and between the commoners and the elites.

The popular films in the 1950s portrayed who the Japanese were during the war, who they were in the 1950s, and how they should behave facing physical violence. At the same time, these are cautious tales about the reproduction of the existing social order. 
Japanese commoners are not supposed to have any ambitious dreams. Rather they should be content with small, everyday forms of happiness, and that is how a democratic Japan should look like after the war: a general population content with modest luxuries governed by benign superiors.

Ugetsu (1953) directed by Mizoguchi Kenji, is set in a small, desolate village near Lake Biwa during the later warring period. Genjurō and his wife Miyagi live in a house near his sister Ohama, and her husband, Tōbei. Both Genjurō and Tōbei are unhappy about their lot as commoners, and wish for a different life. Genjurō hopes to take advantage of war time demand for commodities to sell his pottery and grow wealthy. Tōbei hopes to become a samurai.

Ohama is not happy with her husband's ambition. Miyagi first is happy about her husband's success, but then advises Genjurō to not be too greedy. Eventually he becomes completely preoccupied with his pottery and obsessed with the idea of monetary success. Helping Genjurō, Miyagi mutters to herself, "(Miyagi) You are a different man now. Always so irritable. I just want us to work in peace as husband and wife, and for the three of us to live happily together. That's all I wish for" (Mizoguchi, Ugetsu, 1953). As the story develops, both ambitions bring about bitter ends. Genjurō, who left for the city to sell his pottery, comes home only to find out that his wife Miyagi was killed by a bandit during his absence. Tōbei manages to dress like a samurai using the money he made with Genjurō and then received a reward for finding the head of an opponent general, but he then discovers that his wife become a prostitute after being raped by bandits. Genjurō and Tōbei both learn lessons. Genjurō decides to dedicate himself to becoming a great potter, while Tōbei also decides to work hard with Ohama in the village. They are both humbled. 
Ugetsu is a straightforward morality tale about who commoners are, and how they should behave after the war. Commoners have the means of production in their hands, and are therefore better than the beggars. They have healthy bodies and are able to work hard, but can easily make a mistake by forgetting about the virtue of being appreciative for what they have. At the same time, these peasants were naturally capable of learning what is right and what is wrong. It should be noted that this film also shows the typical images of postwar Japan. Similar to the women that were discussed in the previous section, Ohama is raped, then becomes a prostitute, but recovers her identity of wife by reuniting with her husband. Tōbei is a sneaky former solider who also decides to reform himself. Genjurō is a greedy merchant, but he also decides to reform himself and become a humble potter.

Another film, Seven Samurai (1954) presents the story of peasants in a village who decide to hire seven masterless samurai (rōnin) to protect them from bandits. The film then explores what those peasants and the superior other Japanese (good samurai) should do when faced with external attack. The peasants in Seven Samurai are small people who cannot afford to be ambitious. They must struggle to maintain their frugal everyday lives. From the beginning, it is emphasized that the peasants are poor oppressed victims, helpless against the violent bandits. Learning that the bandits who had brutally plundered food from them were planning to come back to attack them, the peasants cry and their faces are filled with agony. One peasant even tearfully screams that they should commit suicide after letting the bandits have all of their food. While all the peasants cry or let their heads droop with fear, confusion, and helplessness, Rikich, a young peasant, 
proposes to kill the all bandits so that they would not come back again. Another older peasant, Mansaku, simply says that he does not think such resistance would be possible. (Mansaku) We don't have a chance against bandits. And when we lose? They'll slaughter us all, down to the last unborn child. (Rikichi) I've had enough! Better to risk it all than to live like this. Kill or be killed.

(Mansaku) The peasant's only choice is to endure. We cannot defy the powerful. (Kurosawa, Seven Samurai, 1954)

These conversations bring to light the desperation and helplessness of these peasants. The peasants somehow agree to ask for advice from the village leader. They all walk toward the house of the village leader, but the background music is very dark, reflecting their deep disappointment with the situation. Their misery does not stop there. After deciding to hire samurai to defend their village, they still face difficulty finding good samurai. Mansaku says that "peasants like us know good from bad when it comes to seed, but not when it comes to samurai" (Kurosawa, Seven Samurai, 1954). When the peasants finally find Kanbei, who refuses their offer but at least listened to them, they again start to cry. Looking at their misery, a city dweller says, "Good thing I wasn't born a peasant. Better to be born a dog. Goddamn it. Go ahead - hang yourself and die. You're better off dead!" (Kurosawa, Seven Samurai, 1954) Feeling bad for the peasants, the old samurai Kanbei agrees to help them and finds six other samurai to join him.

The relationship between the peasants and the samurai is not based on respect or trust. When the seven samurai arrives at the village, the peasants do not even come out to greet them, showing distrust. They only come out to ask for help when Kikuchiyo, one of 
the seven samurai, lies about the bandits coming to the village. As the samurai start training the peasants, it is seen that the peasants are not simply victimized by the samurai. The peasants have no problem killing defeated warriors on the run and even stealing their belongings and weapons when they can:

(Kikuchiyo) What did ya think these peasants were anyway? Buddhas or something? Don't make me laugh. There's no creature on earth as wily as a peasant! Ask'em for rice, barley, anything, and all they ever say is, "we're all out." But they've got it. They've got everything. Dig under the floor. If it's not there, try the barn. You'll find plenty. Jars of rice, salt, beans, sake! Go up in the mountains. They have hidden fields. They lie, playing innocent the whole time. You name it, they'll cheat you on it! After a battle, they hunt down the losers with their spears. Listen to me. Peasants are misers, weasels, and crybabies! They're mean, stupid, and murders! Damn! I could laugh till I cry! But tell me this: who turned them into such monsters? You did! You samurai did! Damn you to hell! In war, you burn their villages, trample their fields, steal their food, work them like slaves, rape their women, and kill them if they resist. What do you expect them to do? What the hell are peasants supposed to do? Damn it! Goddamn it! (Kurosawa, Seven Samurai, 1954)

What Kikuchiyo says about the peasants typically reflects the elites' images of the peasants. But at the same time, the peasants are still represented as the victims of wars and conflicts.

Kikuchiyo represents the Japanese who were essentially peasants, but now look like samurai. He pretends to be a samurai, but he still is a peasant and bonds with 
peasants better than samurai. That is why, after Kanbei told Kikuchiyou that he must be from the peasant class, Kikuchiyo decides to sleep in the horse barn with Rikichi, who let the samurai use his room due to the class difference between the samurai and the peasants. Rikichi also tries to leave the barn so that Kikuchiyo can use the space, but then Kikuchiyo tells him not to be nervous and to stay there with him. Kikuchiyou is more comfortable with Rikichi than with the samurai, implying that his original identity, the peasant, still makes him who he is.

The samurai make a plan to defend the village and teach the peasants how to fight. The peasants are not comfortable as soldiers, but they do their best. The samurai and the peasants successfully kill all the bandits, although some of the peasants, as well as four of the samurai, lose their lives. In the end, the peasants are happily planting rice with upbeat, cheerful music. The face and the body of a young peasant Rikichi, who in the beginning had been in pain and anger, is seen to have turned into a big shining smile as he hits his drum in the sunlight. He sings a song with a big strong voice. The peasants are happy to have recovered their identity as the peasants who produce rice. The three samurai who survived the fight look at them from a distance. After this victory, none of the peasants have tried to become a samurai like Kikuchiyo.

In the end, the story is about the peasants and their identity as commoners under threat, but who are able to recover successfully the simple identity they should have. Their experiences with the samurai and their victory against the bandits did not change but only restored the existing order. There are samurai and peasants. They could work together and the peasants could fight in the battle, but their happiness is only possible when they are doing things that enable them to be peasants in the traditional sense. 
In addition, the interaction between Shino, a daughter of a peasant, and Katsushirō, a youngest samurai, denies the possibility of bonding between a peasant and a samurai. Shino approaches Katsushirō, and they spend a night together. Shino's father is furious, chases and hits Shino, and tells her that no advancement in this relationship is acceptable. If Shino marries Katsushirō who has higher social status, Shino's status and her father's status could be improved. Yet, the film emphasizes that even though the peasants are subordinate to the samurai, the male peasants dominate the women including their daughters and wives (Rikichi's wife was also given to the bandits to save the village). As Desser (1981) observes, the cultural differences between the peasants and the samurai prevent them from co-habitation in the same village. Desser (1981) argues that Kikuchiyo, who could have the combined identities of samurai and peasant, is only able to achieve the identity of samurai by bravely fighting and dying in battle. Such acts are simply not what the peasants would normally naturally do.

Sansho the Bailiff (1954) is the male narrative version of the fall and rise of the Japanese. If the Japanese women's honor is secured by doing right for the family through marriage, the Japanese men's honor is recovered by doing the right things for the society. This is also a morality tale about a son who made a mistake by bonding with the wrong father, but then corrects his mistakes by bonding with right father. This film confirms the wrongness of male bonding through shared violent acts. Resolving the problem by violence is carefully avoided. When the son follows his good father by doing the right things for society while sacrificing his own interests, he successfully reunites with his family. 
The protagonist is a young Japanese man, Zushiō. The tragedy begins when his father, a good governor, is exiled and Zuzhiō, his sister Anju, and their mother Tamaki are captured by bandits on the way to reunite with him. Tamaki is sold to a brothel. Zushiō and Anju are sold to Sanshō who owns a slave camp. Both Zushiō and Anju work hard as slaves, but as time passes, Zushiō starts doing dirty jobs for Sanshō to get ahead. Sanshō's violent nature is underscored by his treatment of slaves. He leaves slaves who no longer are productive in the woods to die. He punishes slaves who attempt to escape by branding their faces. Ordered by Sanshō, Zushiō brands the face of an old male slave who tried to escape when Sanshō's own son refuses to carry out the punishment.

Zushiō's redemption begins when Anju helps him escape from the camp. Zushiō is eventually discovered by a governmental official and later becomes a governor. As a governor, he bans slavery and exiles Sanshō and his family. But Zushiō is forced to resign his position because of an unhappy higher official who had financially benefitted from Sanshō's camp. This suggests that even though Zushiō makes a change by banning slavery in his prefecture, it most likely will not change the rest of the world. In the end, however, Zushiō manages to recover his family. Sanshō the Bailiff also carefully avoids giving moral superiority to the slaves as the victims. To confirm this point, there is a scene in which the former slaves are dancing and drinking wildly at Sanshō's residence. Amid wild partying, the house catches on fire and is eventually burned down.

Zushiō then travels to a small island to find his mother. The residents of the small island tell him that she died in a tsunami. Wondering on the shore, Zushiō hears his mother singing a song. Zushiō asks forgiveness from his mother for failing to rescue her 
as governor. His mother replies that he did the right thing in following what his father taught him, and that is why they could be reunited.

The film Godzilla (1953) also carefully avoids celebrating the victory by the use of violence. In Godzilla, Dr. Serizawa is the hero who saves Japan from further attacks by Godzilla. Dr. Serizawa is an excellent scientist, but very unsocial, partially due to his unfortunate experience having lost one eye during World War II. He is engaged to Mariko, the daughter of his boss, but then breaks off the arrangement due to his disfigurement. Dr. Serizawa still has feelings for Mariko, and tells her about the "oxygen destroyer," but he refuses to use it against Godzilla. Dr. Serizawa says he would rather keep the technology to himself since it could easily be used as a deadly weapon.

Mariko convinces Dr. Serizawa to use the oxygen destroyer against Godzilla, but he then killed himself during the mission so that the technology would be kept with him forever. Yet, he also makes such a decision after realizing that Mariko is in love with his friend Mr. Ogata. He is able to save Japan without dying, but his death could have freed Mariko, who felt guilty for leaving Dr. Serizawa and being with Mr. Ogata. Thus, Dr. Serizawa not only defends Japan, he also protects the young couple who signifies the now recovered Japan. In the next Godzilla film, Godzilla Raids Again (1955), Japan again faces massive external threats by Godzilla. This time, the film eases the anxiety of the Japanese for the preparedness for the external attack, but at the same time, portraying the use of violence as a counter solution is carefully avoided. In Godzilla Raids Again, the young Japanese salaryman who works for a marital fishery company successfully sinks Godzilla in the snowy mountains, so that Godzilla, a kind of reptile, hibernates instead of being killed. 


\section{The Post-1945 and Post-Occupation Moral Japanese Man}

In official Japanese discourse, there were rarely discussions of the Japanese as moral subjects. In postwar novels and movies, however, the "good Japanese" - the heroes who could save the country-were routinely singled out. The heroes in the films and literature of the 1950s have an interesting commonality: they are men without love in their lives, what Barrette (1989) calls "the chaste warrior[s]." Such moral Japanese men can be seen in the popular films produced in the late 1930s and early 1940s when Japanese society was shifting from feudal to capitalist (Standish, 2000). The end of feudal society meant the loss of loyalty - the most significant value for a moral Japanese man. In the absence of a woman, which is a necessary condition for being a moral Japanese man, he now must be a good person and father whom his son can admire (Standish, 2000).

The typical Chaste Warriors in Japanese films are the swordsmen in the period films ${ }^{4}$. The ideal swordsman is courageous, does not show a fear of death, and is often celibate (Barrett, 1989). A warrior cannot be an ideal figure without distancing himself from women - especially his own wife. For example, in Seven Samurai, good samurai do not even talk about their families. They do not show any interest in the women of the village. It was the bandits who stole women, including the beloved wife of the peasant, Rikichi. One of the good warriors ended up being killed during a raid on the home of the bandits due to Rikichi's affection for his stolen wife. Similar "chaste warriors" can be seen in the film Hidden Fortress (1958) as well. But as has been seen in the previous

\footnotetext{
${ }^{4}$ Period films are called "Jidaigeki" in Japanese.
} 
section, the post-occupation sons, the peasants, politely decline to bond with these heroic fathers.

Japan needed an ideal father, but the post-World War II and the post-occupation version of this ideal required a new kind of father. The film To Live (1952) by Kurosawa Akira does just that job. The protagonist, Watanabe Kanji learns to become a modified version of a hero. Watanabe is a widower living with his son and daughter in law. He is a passionless public worker only waiting for the day of his retirement. After learning that he will soon die due to terminal cancer, he starts thinking about the meaning of life. At first, he is desperate, spending his saving and living a hedonistic life. He drinks, wastes money in game parlors and strip clubs, and starts to spend time with a young female former colleague. She tells him that he should try to create something. Watanabe decides to devote himself to transforming a polluted area into a public park where residents, especially children, can enjoy themselves.

What is different in this film is the father and son relationship. According to Satō (1982) "a beautiful relationship between a parent and a child is the most secure form of social order" but "when this trust is missing, human beings have to bind society with something that has a more universal meaning, e.g., work for the public welfare or common good" (p.129). Watanabe felt he had sacrificed his life enough for his beloved son. Yet, his son was only waiting for his father's retirement money so that he could have a better life with his wife. So, Watanabe reaches the conclusion that "if modern youth rejects the beauty of the trust between father and son, one should cast them aside without regrets, with the consequence that work becomes the sole purpose of life" (Satō, 1982, p. 128). From this line of analysis, the contemporary hero maintains his nurturing task only 
when his son trusts him. His nurturing task can be extended to those people he helps through public service, but this is an exception considering how the story ends in this film. After Watanabe passes away, his colleagues discuss his accomplishment, and reach the conclusion that they should devote themselves to public service like Watanabe did. Yet, in the end, the viewers learn that nothing has changed in their attitudes toward their jobs and lives. This ending confirms that Watanabe could contribute to the public good without disturbing any existing social order or prompting any revolutions or uprising. It may feel disappointing, but peace and order is maintained.

An ethical and moral father by Japanese standards should have only one purpose for daughters: to find them a good husband and home, lest the family be torn apart. The weakened family is associated with a weakened patriarch. Tokyo Story (1953) makes just this case. In Tokyo Story, Noriko, the daughter-in-law and widow of their son, maintains her economically independent widowhood without corrupting herself like the fallen women we have seen in the previous sections. Noriko also is not a dangerous independent woman who makes failed men possible as we have discussed previously. Instead, she lives an economically humble and yet contended life. Thus, Noriko's remarriage serves mainly for the recovery of the power of the weakened patriarch, who again knows better than anyone else in the family. The weakened patriarch expects not only his own blood daughters, but also his former daughters-in-law to obey him because that will save the unity of the family. This may conflict with Noriko's will and desire, but it is the right thing to do. 


\section{Japan, the Self, Others, and the World}

In the early post-occupation era, Japan sought to transform itself from a defeated and occupied country into a "Liberal, Democratic, Peaceful, and Independent Japan." How should a Liberal, Democratic, Peaceful, and Independent Japan look, and how should such a Japan orient itself to the rest of the world?

The ideal world -peaceful, ordered, and stable - is possible when the hierarchical relations between the patriarch and the rest of the family members are stable. The patriarch knows and is capable of doing what is right for the family. The rest of the family members have to obey him, which is the right thing to do for the sake of the maintenance of the family and is equivalent to a peaceful, ordered, and stable world. The identity of the ideal patriarch is constitutive of the ideal for the rest of the family.

Now it is possible to draw a hypothesis about Japan's foreign and security behaviors assuming that this Japanese patriarch's understanding of how the world should look translates into Japan's understanding of itself and the rest of the world. In the eyes of the patriarch, the world is made of various people. Some are good, some are bad, some are dangerous, and some are violent. Such a world is totally normal and acceptable in the eyes of the patriarch. What this Japanese patriarch is familiarized with are the somewhat incomplete forms of family. These are often portrayed as different from a complete family consisting of a father, mother, and children, though the patriarch is very sure that the wife and husband relationship is ideal, and the daughter must marry or be reunited with her husband after the war. This normalcy of a somewhat incomplete family suggests that Japan also would not necessarily seek the union of the nation-states, which would 
invoke the image of the complete family. This visions contrasts with that of Imperial Japan, which dreamed that almost all Asian states should be its daughters or sons.

Also, the Liberal, Democratic, Peaceful Japan sees it as natural that a minimum of interventions are necessary to correct the problems such as dangerous women or men. The acceptable means are mostly non-coercive measures. And in the films, many issues are resolved not because of someone's purposeful goal-oriented actions. Occasionally, the Japanese daughter sacrificed herself to save a Japanese man, but most likely spontaneously and not by the order of the patriarch. At the same time, sons are not supposed to bond with the violent others because those sons can be easily corrupted. This suggests that Japan's distrust of its own people should partly motivate Japan not to remilitarize.

Japan's relations with great powers are understood through the lens of relations between the patriarch and his sons or daughters. Japan plays the role of the son or daughter; thus, Japan will not challenge the dominance of the great powers including the U.S., the Soviet Union, and China. Compared to small and beautiful Japan, they are physically bigger and their status is higher (the victors of the World War II, for example). Japan's relations with these great powers will be justified based on the perspective of Japan as the patriarch. In the films, there were two distinctive solutions. The daughter marries whom the patriarch approves, and the sons disassociate themselves from the violent fathers and concentrate on work. The former suggests that Japan must follow American directives. The later suggests that Japan can achieve independence through hard work and economic development rather than military means. But at the same time, Japan as the patriarch has to make sure that Japan will bond with the right great powers 
who care about protecting the people of Japan, just as the patriarch does for the daughters and sons.

What, then, does "marriage" mean in terms of foreign and security policy? This has to be elaborated a little bit more. Kant's definition of marriage here might be helpful. Kant defined marriage as an act of giving his or her partner an exclusive access to sex under the marriage contract. Marriage is also about the relationship between the two families or patriarchs. Thus, marriage will be some sort of legal agreement between the two countries by which one country allows another to have exclusive access to part of the country. In Japan's context, the husband has exclusive access to the wife's body while the same rule is more loosely applied to the husband. At the same time, the father of the daughter expects that the daughters will be secured in the sense that she would not become a fallen woman, but he also expects that his and the family's social status will to increase if the marriage is successful.

Japan's relations with minor powers will be understood in the same way, but this time, Japan is the patriarch and the minor powers are equivalent to Japan's sons and daughters. The minor powers must willingly obey Japan. Yet, Japan as a liberal, democratic, and peaceful state, must refrain from they use of coercive measures when these minor powers do not obey. Thus, Japan's foreign policies will be limited to the diplomacy and foreign aid. The use of force will be unacceptable. Problems must be resolved through negotiations or Japan must wait until the minor powers change their policies for their own reasons.

This Japanese worldview functions as an unconscious ideology. Japan's foreign and security decisions may or may not reflect how this worldview guides Japanese 
behaviors. But over time, Japan's foreign and security policies will show the features that reflect this worldview. I will explain Japan's foreign and security behaviors in the 1950s in the next chapter to demonstrate how this worldview and Japan's identity as a liberal, democratic, and peaceful country shaped Japan's foreign and security policies. 


\section{CHAPTER 3:}

\section{RESTORING THE PATRIARCHAL ORDER AT HOME AND ABROAD \\ Introduction}

Japan's foreign and security policies during the early post-occupation era (the late 1940s to the late 1950s) can be better understood through the exploration of Japan's conscious and unconscious desire to restore its ideal patriarchal order at home and abroad. Irrespective of the various challenges Japan faced during the post-occupation era, its foreign and security policies were significantly shaped by ideals that can be clearly understood through analysis of the popular films conducted in the previous chapter.

Japan maintained and further developed distinctively asymmetrical power relations with the U.S. that can be seen as allegorical to the relations between the good patriarch and the rest of the family members. At the same time, Japan avoided rebuilding its military to the degree desired by the U.S. much in the same way that an ideal Japanese son would avoid bonding with a violent and dangerous father figure.

In Japan's relations with the Soviet Union-led Eastern Bloc, Japan preferred to avoid open hostility with the USSR and the PRC. Japan managed to do so in a very limited manner due to Japan's respect for the relations with the U.S. as Japan's guardian. Japan also sought to construct amicable relations with the Asian neighbors who were hostile or unfriendly to Japan due to Japan's past wrongdoings. Instead of seeking a sincere reconciliation though, Japan's relations with the U.S. enabled Japan to resolve war responsibility issues through economic cooperation, not war reparations, and only with the countries that agreed to reciprocate something to Japan such as the repatriation of Japanese people. 
This chapter explains Japan's behaviors as a practice of temporally correcting an insecure identity of Japan Self as a result of the defeat and the occupation. Japan's major source of insecurity was its identity as the defeated and the occupied, and to fix that identity, Japan needed to transform into a proudly independent, liberal, democratic, and peaceful nation. It was demonstrated that unconscious ideologies over time shaped Japan's foreign and security behavior. At the same time, Japan's understanding of the self as a significant other to the U.S. helped Japan define its relations with the rest of the world. It was impossible for all of these behaviors with a range of others to co-exist without the narratives seen in Japanese popular films of the time, which equated a peaceful Japan to the hierarchically ordered society.

\section{Japan's Foreign and Security Policies in the 1950s}

\section{Japan - U.S. Relations: U.S. as Fatherly Figure to the Nation of Japan}

Japan desired to realize its imagined ideal relations with the U.S. These relations were allegorical to the relations between the good patriarch and the rest of the family members. The good, liberal, democratic, and peaceful patriarch knows what is the best for the family, and the rest of the family members should be willing to be guided by the good patriarch. Throughout the 1950s, Japan unconsciously sought to affirm that it was willingly obedient to the U.S. out of respect for the U.S.' benevolence and guidance.

After the lengthy negotiation with the U.S. on the terms of the peace treaty, the Japanese government finalized the San-Francisco Peace Treaty (SFPT) agreement on September 8, 1951, and also established a security treaty with the U.S. On February 28, 1952, Japan signed the Administrative Agreement under Article III of the Security Treaty between the United States of America and Japan. On March 8, 1954, Japan concluded the 
Mutual Defense Assistance Agreement with the United States. On June 9, 1954, Japan issued the Defense Agency Establishment Law and renamed the Japanese National Safety Forces to the Japan Self Defense Forces (SDFs) together with other three agreements. On January 19, 1960, Japan signed the Treaty of Mutual Cooperation and Security between the United States and Japan.

The Japanese government ended up choosing not to conclude a peace treaty with the USSR and China, and instead decided in favor of a security arrangement with the U.S. The U.S. plan Japan agreed to was as follows: 1) The U.S. would maintain its military presence in Japan; 2) Japan would lightly rearm itself; 3) Japan would not develop economic relations with certain countries opposed to the U.S., particularly China; 4) The U.S. would support Japan's economic development, therefore discouraging the demand for war reparations by other states who desired to pursue them; 5) The U.S. would support Japan's bid for UN membership.

At first glance, this arrangement has advantages and disadvantages, but these three documents show a path for Japan to transform itself from the defeated and the occupied to the proud and independent Japan. One of the significant features of this framework was the willingness of the U.S. to help Japan improve its international status. The U.S. had already shown a strong interest in Japan within the context of the Cold War and the heightened tensions between the U.S. and the Soviet Union. As early as 1948, the U.S. referred to Japan "as a central part of the containment doctrine" (Pyle, 2007, p. 221). In addition, the realization of a proud, independent Japan through economic development would be assisted by the U.S., with whom Japan bonded through the security treaty and 
the administrative agreement. The U.S. also expressed its support for Japan's future membership in the UN.

The U.S. also wanted to see an improvement in Japan's economy so that it would be strong and stable enough to resist any attempted penetration by the Communist countries. The disadvantage was that the U.S. did not want Japan to have economic relations with the newly established Communist China, although Japan thought their economy would benefit from promoting trade relations with China. In addition, as Communist China entered the Korean War, Japan also was obligated to participate in UN-administered economic sanctions against Communist China. Accepting this plan meant the continuation of limited economic freedom for Japan. Yet, the U.S. suggested that Japan instead promote economic relations with other Southeast Asian states, which was an acceptable suggestion for Japan to compensate for the expected economic loss from not being able to establish economic relations with China.

As to the Asian states, the SFPT still allowed the countries with tremendous damages as a result of Japan's invasions to seek compensation. Yet, the U.S. also agreed to discourage the demand for Japanese war reparations, emphasizing the importance of Japan's prosperity and stability to the regional stability. The SFPT was a great text in which Japan could project its image of a proud and independent Japan instead of Japan as the defeated former aggressor who should be humiliated and punished.

In sum, the U.S., who was in the superior position to Japan, showed tremendous generosity and even empathy to its defeated erstwhile adversary. Japan as the one who was in the weaker position had to pay respect to and/or obey the U.S. so that the patriarchal hierarchical structure could be realized, while Japan still maintained the 
identity of a liberal, democratic, peaceful, and independent Japan. The 1951 Security Treaty and 1952 Administrative Agreement under Article III of the Security Treaty between the United States of America and Japan, therefore, had to construct U.S.-Japan relations as to resemble to the relation between the good father and the rest of the family members. Japan also would have to benefit from the asymmetrical power relations between the two, so that Japan would no longer look like the occupied, but rather the object of American protection, with the U.S. acting as a good fatherly figure to the nation of Japan.

In order not to look like the occupied, the meaning of the U.S. forces in Japan also had to be transformed from the icon of the defeated and occupied to the againindependent Japan. The U.S. bases evoked a strong sense of humiliation among the Japanese people since many of the sex workers or fallen women were visible around the U.S. bases. The sex workers signified a defeated and occupied Japan. In addition, the Japanese people faced many violent acts committed by occupying U.S. soldiers. The Japanese government had to pay compensation to the victims of the assaults, which were documented 1,112 times in 1951 and 2,374 times in 1952. Obviously, there were other cases that went unreported (Oguma, 2002). The Japanese government was well informed of these problems associated with the U.S. presence in Japan. The U.S. soldiers' mistreatment of Japanese people often signified the misery of the defeated and occupied Japan. Such acts of violence by American occupiers had to be mitigated for Japan to regain its sovereignty.

The 1951 Treaty first attempts to change the meaning of U.S. forces in Japan from one that ensured subjugation to one that supported Japan's independence. The Japanese 
government carefully constructs Japan as the one who desired the U.S. to remain in Japan, based on Japan's assessment of the current asymmetrical military capabilities between Japan and the U.S. Thus, this arrangement does not define the imposed subjugating position of Japan. The treaty reads as follows:

Japan will not have the effective means to exercise its inherent right of selfdefense because it has been disarmed. There is danger to Japan in this situation because irresponsible militarism has not yet been driven from the world. [...] Japan desires, as a provisional arrangement for its defense, that the United States of America should maintain armed forces of its own in and about Japan so as to deter armed attack upon Japan. The United States of America of America, in the interest of peace and security, is presently willing to maintain certain of its armed forces in and about Japan. (Security Treaty Between Japan and the United States of America, 1951)

The rest of this part of the security treaty emphasizes Japan's position as being willingly obedient to the U.S. to the extent that Dower (1969) wrote that "the treaty forced Japan to agree to conditions of inferiority unmatched in any of the other forty plus security treaties negotiated between the United States and other nations in the 1950s" (Dower, 1969, p. 24). Yet in Japan's eyes, its inferiority to the U.S. was the only reason it would gracefully accept help from the U.S., and therefore it was not a problem at that moment when Japan apparently was in the weaker position. Japan's view of the U.S. as a good fatherly figure left Japan unprepared for the possibility that the U.S. would mistreat it and its people. Together with the U.S.' willingness to support the improvement of Japan's political, social and economic standings in the international community, the arrangement fit nicely 
into Japan's image of the ideal family in an ideal world through the embrace of paternalistic interactions.

Japan bonded with the stronger U.S. by willingly subjugating itself to the U.S. Japan still had to cement such relations, and in a way, the asymmetrical power dynamic between the two countries favored Japan, and Japan's willing subjugation looked like the right decision. Throughout the 1950s, Japan's expectation was realized as it interacted with other states. The following sections further explain how Japan constructed its relations with other states. Japan's foreign and security policies in the 1950 s were overall very successful and Japan accomplished many goals that will be discussed in the following sections.

\section{Japan’s Relations with International Organizations}

The 1951-1952 U.S.-Japan Security Treaty was put into effect on April 28, 1952. Throughout the 1950s, Japan's expectations of its new relationship with the U.S. became Japan's social reality. Japan's reintegration into the international community was steadily advanced, which made the arrangements Japan had made with the U.S. appear to have paid off. In the eyes of the Japanese government, the U.S. had been a good partner and helped in the recovery of Japan's economy. Japan later made a bid for membership to the International Monetary Fund (IMF) and was successfully admitted as a member on August 14, 1952. On the same day, Japan was able to join the International Bank for Reconstruction and Development (IBRD), from which Japan ended up receiving $\$ 863$ million in loans between 1953 and 1966 (Togo, 2010). In 1955, Japan was also allowed to join the General Agreement on Tariffs and Trade (GATT). The U.S. supported Japan in gaining access to all of these international financial and trade organizations. As a 
result, Japan was able to bond with the U.S. by concluding the Japan-U.S. Security Treaty, which in turn helped to improve Japan's social status in the international community.

\section{Japan and the Soviet Union in the 1950s}

The Soviet Union did not sign on to the SFPT. As a result, Japan had to negotiate with the Soviet Union bilaterally. In addition to normalizing diplomatic relations with the Soviet Union, Japan had three major issues that they wanted to resolve as soon as possible: 1) territorial issues; 2) repatriation issues; and 3) fishery rights issues. In his speech at the SFPT conference, the first issue Yoshida brought up was that of the Japanese territories occupied by the USSR. Yoshida stated that Japan did not acquire the Kurile Islands and South Sakhalin by aggression, and that the South Kurile, Habomai, and Shikotan islands, which had been occupied by the Soviet Union since 1945, originally belonged to Japan. It was also widely known amongst the Japanese that the Soviet Union had captured about 600,000 Japanese soldiers in those areas that the Soviet Union occupied and sent them to concentration camps (Togo, 2010). Families of the prisoners desperately wanted them back home. Japanese fishing vessels near the four Russian-held northern islands were also frequently seized by the Soviet Union, and this practice made the Japanese fishermen desperate (Morley, 1962).

The USSR was a world superpower, the leader of the Eastern Bloc, and in close proximity to Japan, and as such the Japanese government considered it a serious threat. Japan was much weaker than the USSR, and would have to assume the subordinate position when negotiating with the USSR. However, Japan's view of itself as a partner of the U.S. enabled it to understand its position in relation to the USSR as being much 
stronger, and the interactions also served as an opportunity to test the U.S. commitment as Japan's guardian.

The first opportunity came during the early 1950s. At that time, Japan's relations with the USSR were not at all amicable. Japan was defined as an enemy in the 1950 USSR-China defense pact. Japan's role of an enemy to the USSR and China, however, became an opportunity for Japan to test the U.S. commitment to the defense of Japan, which Japan had been worried about due to the lack of strong wording in the security treaty. The opportunity materialized in 1952 when Japan observed Soviet Union's fighter planes trespassing in Japanese air space as many as fifty times. Japan consulted with the U.S. regarding the violation and the U.S. promised Japan to help repel any USSR attempts at violating Japan's territory. The U.S. later shot down one Soviet MIG-15 (Weinstein, 1971). Through this series of events, Japan could ease its anxiety over the U.S. security commitment, thus Japan felt secure about the security arrangement between Japan and the U.S.

The second opportunity Japan could test U.S. commitment came in the mid-1950s when the Soviet Union suggested initiating peace negotiations with Japan. This time, Japan could test how much the U.S. cared for the Japanese people through the issues of fishery rights and war prisoner repatriation. To satisfy Japan, the U.S. allowed Japan to negotiate with the USSR, and even helped move the process along when the negotiations stalled.

In around 1954, the USSR challenged Japan's new identity as a proud and independent country. The USSR labeled Japan as weak and occupied, citing the presence of U.S. forces as evidence. The Soviet Union suggested that Japan should not align with 
the U.S. The Soviet Union also insisted that repatriation issues should not be included in the negotiations and that all the Japanese people still held in the Soviet Union were war criminals and had to serve their term of punishment in the Soviet territory. The Soviet Union maintained its upper hand over the fishery issues, as well. Japan did show respect for the USSR and agreed to make joint rules regarding conservation and fishing in the disputed territories. Other issues remained unresolved, but Japan remained faithful to the U.S. and rejected the USSR's demand for Japan to stop its security arrangement with the U.S.

In 1955, Japan and the USSR started interacting once again. Japan and the Soviet Union had a hard time reaching any formal agreement on the territorial issues. In 1956, when negotiations became difficult, Japan sought advice from their powerful other, the U.S. The U.S. did not offer to hold a conference with the Soviet Union regarding Japan's territorial disputes, but gave Japan information that prepared them to better deal with the Soviet Union. The U.S. emphasized that the Soviet Union should want to conclude a peace treaty with Japan just as much as Japan wants to. The U.S. also told Japan that the Soviet Union's claim that the U.S. and the UK agreed to the Soviet Union's sovereignty over the Japanese islands during World War II was not true. The U.S. further suggested that Japan could tell the USSR that if it would not compromise on territorial issues, then the U.S. would never leave Okinawa. In order to try to realize a peace treaty with the USSR at that time, the Japanese government considered the option of compromising on territorial issues and accepting the return of only two out of the four islands Japan claimed were illegally seized by the USSR (Togo, 2005). After having confirmed the 
U.S. position against such a compromise, Japan decided not to agree to settle with the USSR.

Japan and the USSR kept interacting, and in the end, Japan managed to achieve rare victories in its foreign policies. On October 19, 1956, Japan and the USSR issued a "Joint Declaration by the Union of Soviet Socialist Republics and Japan" whereby the Soviet Union and Japan agreed to normalize diplomatic relations. The Soviet Union agreed to support Japan's entry to the UN, return two of the disputed islands (Habomai and Shikotan), and to free the Japanese soldiers detained in the USSR. The Soviet Union agreed to the principle of nonintervention in domestic affairs. Japan and the USSR also agreed to continue negotiations over the unresolved territorial issues and to create a new peace treaty. The USSR also voluntarily relinquished its right to war reparations against Japan. Prime Minister Hatoyama stated that it was delightful to see the improvement of Japan's international status from joining the UN, one of the results of this joint declaration. Again, Japan's amicable relations with the U.S. proved to be a tremendous help for Japan to navigate itself in the international community and negotiate with the USSR.

The improvement of Japan's relations with the Soviet Union continued to last for only a short while, until the Soviet Union began to once again treat Japan as an occupied nation. The USSR also challenged the legitimacy of the Japanese government and suggested that the USSR better knew what the Japanese people truly wanted. Specifically, the USSR said that the U.S. presence in Japan harmed the national pride and brought suffering to the Japanese people by possibly dragging Japan into 
unwanted military conflicts. The USSR urged Japan to free itself from foreign occupation and achieve political neutrality.

Japan continuously projected an image as a partner of the U.S. that should be respected by the USSR. The Japanese government emphasized that the 1951 security treaty between Japan and the U.S., as well as the current attempt to renew that treaty, did reflect the true will of the Japanese people. The Japanese government also stated that the people understood the USSR's call for political neutralization to be an attempt to leave Japan defenseless and isolated in the international community. As a great power who signed the document for the unconditional surrender of Japan, the USSR also communicated that Japan should consider the negative ramifications of introducing nuclear arsenals to their country. The Japanese government directly refuted such comments that labeled Japan as a defeated nation. Japan expressed its choice not to arm itself with nuclear weapons, but also emphasized that it would make the decision on its own, and that the USSR should not intervene in Japan's domestic affairs.

Tension escalated when the USSR unilaterally announced that it would not uphold the previously promised return of the two islands of Habomai and Shikotan until the U.S. troops withdrew from Japan. The Japanese government showed its close bond to the U.S. and did not back off. Japan called the Soviet decision "incomprehensive" since USSR was well aware of Japan's security treaty with the U.S. when they agreed to the 1956 joint declaration between the USSR and Japan. Therefore, the U.S. military presence in Japan was an established fact, both then and now.

The USSR remained a powerful other to Japan, but Japan did not have to interact with the USSR as a defeated and occupied nation. Thanks to its close relations with the 
U.S., Japan could proudly negotiate with the USSR, and it achieved may of its foreign policy goals. These patterns again affirmed that Japan rightfully bonded with the benevolent fatherly figure, the U.S.

\section{Japan-the PRC Relations in the 1950s}

Japan's successful relations with the People's Republic of China (PRC), mostly through informal economic and cultural interactions, also confirmed that Japan rightfully bonded with the U.S. Japan officially recognized Taiwan in 1952 in accordance with what the U.S. desired. As a result, Japanese society predicted that Japan would not be able to develop amicable relations with the PRC. This proved partially true, since Japan was not able to normalize diplomatic relations with Communist China until 1971. Throughout the 1950s, U.S.-PRC relations were hostile due to the confrontation over the Korean War and the Taiwan issue. Yet, the U.S. as Japan's significant other enabled Japan to advance economic relations with the PRC. According to Togo (2010) "Japan and the PRC moved into an interesting two decades of primarily economic relations" (p. 120).

In the eyes of Japan, China was a great world power, had the largest territory in Asia, a size almost identical to the U.S. China was also the closest little brother of the USSR during this time. Communist China defeated the U.S.-supported Chiang KaiCheck's Chinese Nationalists, and as a result Communist China was identified as a strong and truly independent Asian power that bravely challenged the U.S. and won. Japan also recognized the historical, cultural, and geographical proximity to China.

Having willingly assumed the subjugated position to the U.S., Japan did not see an opportunity to formally develop amicable relations with the PRC so long as the U.S. and China were in enmity. At the same time, the U.S. was lenient about Japan's 
economic activities. Japan's understanding of the self as the willing subordinate of the U.S. made Japan approach China carefully, in a way that allowed Japan to maintain close relations with the U.S. by supervising the activities of Japanese, but still economically interacting with China. By interacting with China, Japan could project its identity as an independent country whose economic policies were not dictated by the U.S. Yet, when Japan's policy had to be in line with the anti-communist policies, Japan rather looked to be the subordinate of the U.S. As a result, Japan's foreign and security policies were more or less selective and opportunistic.

Japan's opportunity to interact with China became available when the PRC changed its policy towards Japan. After Japan concluded their security arrangement with the U.S., China no longer saw Japan as an enemy or former aggressor who needed to be carefully supervised. Japan rather was a country that was suffering from "an imposed 'colonial' status" (Leng, 1958, p. 7). China now called for Japan to gain true independence in two ways: 1) Japan shall be free from foreign troops in her homeland; and 2) Japan should be free to have economic relations with any state of its choice in order to be able to better develop their economy (Leng, 1958, p. 4).

At the same time, Japan's economy suffered, especially after the special procurement from the Korean War ended in 1953. The economic hardship could have invited amoral behaviors among the Japanese, which would have undesirably signified the weakened patriarch. As a result, Japan acted to advance amicable relations with China, but only at an informal level, and only when China did not challenge Japan's close relations with the U.S. 
Japan and China enjoyed amicable relations from 1952-1957, and again between 1962-1965 (Togo, 2010). China invited various Japanese non-governmental organizations to their country, and Japanese visitors to China steadily increased during the 1950s. Japan's trade with China also gradually increased, although the embargo Japan had to implement was still a significant obstacle to increasing the volume of the trade between the two nations.

China was generous and sensible to Japan's needs. Japan issued the first official passports for the Japanese people who were to visit the PRC in order to negotiate the repatriation issues in 1953. In the same year, about 26,000 Japanese prisoners were allowed to return home from the PRC. In 1955, about 3,000 Japanese prisoners, including close to 400 Japanese war criminals, were allowed to return back to Japan (Leng, 1958). In 1956, 1,017 out of 1,062 Japanese detainees were also allowed to return home (Leng, 1958). The PRC also decided not to demand war reparations from Japan (He, 2007).

Japan's relations with China did deteriorate during the late 1950s when Prime Minister Kishi tested to see if Japan could project the identity of being anti-communist. In 1957, Prime Mister Kishi visited Taiwan and implied his support for Taiwan, who had expressed its will to take control of mainland China. Japan also did not accept the PRC's request to fly their own flag for trade missions in Japan. Nor did Japan press charges against the two Japanese people who damaged PRC goods in 1958 that were being displayed at a department store.

These acts outraged the PRC and Japan-PRC interactions were interrupted. From the perspective of Japan's understanding of the self as the patriarch, however, Japan's actions made sense since priority should be given to the overall increase of Japan's 
international status, for which the U.S. had been greatly helpful. Throughout the 1950s, Japan's relations with the PRC were much better than Japan could have expected considering the enmity between the U.S. and the PRC. Japan preferred to interact with China only in ways that would not compromise Japan's close relations with the U.S.

\section{Japan and Newly Independent Asian States}

Japan's close relations with the U.S. further helped Japan project its identity of a proud new Japan in relations with newly independent Asian states. Japan understood itself as a non-great world power, but Japan often described herself as being in a leading position among the countries in Asia even after the defeat in World War II. When asked about Japan's future foreign policy with their Asian neighbors, Prime Minister Yoshida expressed that: "I wish Japan to lead other liberal states in Far East or Asia so that it can contribute to world peace and freedom. This want I believe is what the Japanese nation wants as well." The Japanese government often stated that Japan's advanced technologies would be beneficial to underdeveloped Asian countries. In 1957, Japan emphasized that they would promote good and friendly relations with neighboring Asian states (Ministry of Foreign Affairs of Japan (MOFA), 1957).

If Japan had to interact with other Asian states as the defeated former aggressor, Japan would have to assume an inferior or weaker position, which would contradict Japan's understanding of itself as a leader in Asia. Many Japanese also wanted to believe that Japan fought for the liberation or defense of Asian states from European colonialism. At the same time, Japan knew that in the past, Imperial Japan did engage in various forms of improper conduct in other nearby Asian countries and now those proud newly- 
independent states would not shy away from demanding Japan to be responsible for its past behaviors.

Japan's hierarchal worldview structure of the subordinate and the superior allowed Japan to view itself as the superior that should be respected when it came to relations with other Southeast Asian States. Unconsciously guided by this worldview, Japan tried to restore normal relations with their neighbors by refusing to interact as the defeated, instead choosing to interact as the proud new Japan whose successful achievement of prosperity and stability were shared goals for those other Asian states.

At the same time, Japan still maintained the identity of a liberal, democratic, and peaceful Japan who would not resort to coercive measures to achieve its foreign and security policies. Japan did not mind taking their time for diplomacy until the social reality matched the imagined reality. At the same time, Japan's close relations with the U.S. prompted Japan to differentiate itself from other Asian states who were close to the U.S., namely South Korea and the Philippines. Like Japan, both South Korea and the Philippines concluded a security treaty with the U.S. Parallel to the hierarchy among the women in the "reel world," Japan sought to assure its superior position to these two countries, which made Japan making any concessions very difficult. In the next three sub-sections, I will demonstrate: 1) how Japan could not reach any agreements with South Korea; 2) how Japan managed to normalize diplomatic relations with the Philippines; and 3) how Japan was able to easily restore relations with Burma. The case examples used demonstrate how unconscious ideologies shaped Japan's interactions with these three neighboring Asian states. 


\section{Japan and South Korea: Disorder among the U.S. allies}

Japan's foreign and security policies toward South Korea in the 1950s were a complete failure. Japan failed not only to normalize diplomatic relations with South Korea, but also failed to reach any agreements for solving practical problems between the two countries. Initially, it was the U.S. who urged Japan to start normalization talks with South Korea shortly after the SFPT. Japan's sense of superiority to South Korea was confirmed by the U.S.' understanding of South Korea; insofar, as the U.S. did not recognize South Korea as one of the victors of the World War II. Nor was South Korea invited to the SFPT conference. The U.S. also did not support South Korea's demand for war reparations from Japan.

In October of 1951, Japan began talks with South Korea. Japan thought negotiations with South Korea would be easy, despite that it was widely known that South Korea had a negative view of Japan. South Korea turned out to be very confrontational and the talks stopped after the two countries found that they were not even able to agree on which issues to discuss. South Korea wanted Japan to act as a defeated nation and pay reparations, fully admitting responsibility for its misdeeds during the colonial period, which was unacceptable to Japan.

Japan's uncompromising approach to South Korea resulted in South Korea implementing its border control policy in the sea. From 1952 to 1964, South Korea captured 232 Japanese fishing boats and made 2,784 Japanese fishermen serve prison terms, ranging from a few months to years at South Korean detention camps (Oda, 1967, p. 51). Japan began another round of talks in February of 1952, but was again unable to effectively communicate with South Korea. Unlike its relations with the U.S. or China, 
Okazaki said that South Korea was acting as if it was one of the victors of the war and a member of the Allied Powers. Okazaki said that South Korea claimed the following: 1) South Korea would be doing a favor in recognizing Japan as an independent sovereign nation state; and 2) South Korea would demand reparations.

At home, Japan had to resolve the issue of the legal status for Korean residents in Japan. On April 19, 1952, Japan announced that Koreans living in Japan would automatically lose their Japanese citizenship once the SFPT was put into effect. In domestic discourses, the Japanese government continuously mentioned that there were both good and bad Korean residents in Japan. Good Koreans successfully assimilated themselves to Japan as a result of Imperial Japan's assimilation policy during the colonial times. These Koreans were dutiful, and if they wanted to live in Japan, the Japanese government should provide support. Disgraceful Koreans were illegal immigrants, or the ones who engaged in criminal activities. Some of the poor Koreans may not have been malicious, but they were a burden for Japan. Japan kept deporting these "bad Koreans" to South Korea during the 1950s. On May 12, 1953, the South Korean government decided not to accept those Koreans back to South Korea, which became another source of trouble for Japan. Japan continued to expect South Korea to be cooperative after South Korea became an ally of the U.S. in 1953. Japan thought that together Japan and South Korea had cooperatively realized the U.S. wish for them to resolve the issues of fishery rights and the legal status of Koreans in Japan.

Japan and South Korea again began negotiations on October 6, 1953, but the talks broke off by October 21, 1953, after which Japan was totally confused about how to communicate with South Korea. The major reason that negotiations reportedly ended was 
that the Kubota Japanese representative made a reckless and infuriating remark towards South Korean representatives. When questioned at the Diet, Kubota provided the details of the conversation between Japan and South Korea. According to him, South Korea suggested that they could have demanded reparations for the damages Japan did to Korea during the colonial rule. In response, Kubota told them that was not a good idea. If South Korea suggested such a thing, Japan would have pointed out their contributions for modernizing South Korea. South Korea demanded that the Japanese official withdraw his comments, but Kubota refused to do so since he was telling the truth. The Japanese government even suggested that South Korea originally had unreasonable attitudes towards Japan in the following ways: 1) Japan had more at stake for the agreement than South Korea; 2) South Korea wanted to treat Japan as a defeated nation; 3) South Korea saw itself as a hero of that time.

South Korea's claimed identity was not something Japan could have comprehended. When the Japanese government suggested that South Korea might have planned to break off negotiations no matter what, a Diet member argued that it was Japan's mistake to make comments in defense of the Empire of Japan knowing that the South Korea's official position strongly despised imperialism. Another Diet member said that the conversation sounded childish, but the Japanese government claimed that it was South Korea that was childish, which on a side note, really does beg the question of who is childish. The Japanese government continued to label South Korea as unreasonable, aggressive, and irrational. Japan had been sincere in the negotiations and was going to urge South Korea to reflect upon its behaviors. Later, the Japanese government started saying that both Japan and South Korea should resolve this problem based on the spirit of 
mutual concession, but Japan never admitted that the comment that justified Japan's colonization of South Korea was wrong.

On December 12, 1957, citing a U.S. memorandum, Japan finally decided to compromise, withdrew the Kubota comments, and gave up its claim to the private assets of the Japanese that were left in Korea. South Korea agreed to release the detained Japanese fishermen, and Japan agreed to return Korean detainees to Japan. Japan and South Korea held more talks shortly thereafter, but those did not last long. South Korea was not happy about Japan's amicable attitudes toward communist states, and Japan later sent Korean residents in Japan to North Korea. Throughout the negotiations, Japan not only tried to project the identity of a proud new Japan, but also Japan's superior position to South Korea, who also had close relations with the U.S. As a result, Japan was unable to consider any concessions on these practical issues Japan had with South Korea at that time except when the U.S. guided Japan to do so.

Japan-Southeast Asian States Relations: The success Case of Burma and the Troubled Case of Philippines

Japan had managed to normalize relations with other Southeast Asian states during the 1950s, which were structured around the issues of reparations and compensation for the war damages previously caused by Imperial Japan. In the official discourse, Japan called for maintaining their membership among the other Southeast Asian States. In the 1957 Diplomatic Bluebook, it was also stated that having friendly neighbor relations with Asian states with whom Japan shared a geographical proximity, as well as psychological bonds from having racial and cultural similarities, was an important object of Japan's foreign policy. 
Japan's understanding of Southeast Asian states as naturally willing subjects to help Japan's economic development can be explained by Japan's understanding of itself as a significant other of the U.S., who wished for Japan's swift economic recovery in order to prevent communism from possibly taking over in Japan. At the same time, Japan was fully aware that the bitter memories of Imperial Japan's wrongdoings were still fresh in the minds of Southeast Asian States and could possibly define Japan as the defeated former aggressor. Such would contradict Japan's new identity as a liberal, democratic, and peaceful country.

Japan made reparation agreements with Burma in 1954, the Philippines in 1956, Indonesia in 1958, and Vietnam in 1959. Japan agreed to provide economic assistance to Laos and Cambodia since these two countries did not seek reparations. During the 1960s, Japan also agreed to provide compensation to Thailand, Malaysia, and Singapore (Togo, 2010, p. 196). Among all of these examples, the two contrasting cases of Burma and the Philippines will be examined.

\section{Burma: Cozy relations with an Asian friend}

Burma did not sign on to the SFPT, and a peace treaty had to be concluded on a bilateral basis. The U.S. support of Japan did not mean much to Burma since Burma had expressed a neutralist foreign policy, and there was no U.S. pressure to normalize relations with Japan.

Japan had distinctive images based on its historical relations with Burma. Japan had provided support for Burma's movements for independence from the Europeans since the 1930s, hoping to eventually incorporate Burma into Japan's own empire. This arrangement ended when Burma decided to side with the allied forces in March of 1945, 
anticipating the defeat of Japan in the near future (Strefford, 2010). Still, the fighting Japan did in Burma was fierce and only less than $40 \%$ of the Japanese soldiers sent there between 1941 and 1945 returned. The unexpected kindness of the Burmese villagers who offered food and medicine to the retreating Japanese soldiers was still made a part of the Japanese war memories (Seekins, 2007).

Negotiations went relatively smoothly and were brief since Burma did not challenge Japan's new identity. Formal negotiations began in August of 1954 and Japan and Burma signed a peace treaty and reparations agreement by November of that same year. In the process of negotiations, Burma was sympathetic to Japan's need and did not demand things Japan would consider unreasonable. Burma also allowed the Japanese to gather the remains of those who died in Burma, which was understood as a sign of Burma's compassion. Japan was not treated as the defeated and Japan instead was able to project an image of the peace-loving Japan who aspired to contribute to the stability of Southeast Asia through nonviolent means, which were economic policies.

\section{Philippines: Uneasy Relations}

Japan's relationship with the Philippines is an interesting case since the Philippines were occupied by the Imperial army of Japan from 1942 to 1945 before gaining independence in 1948. Unlike Burma or South Korea, the Philippines was a signatory of the SFPT, but had not ratified it until the reparations agreement was formulated with Japan. Yet, despite these differences, Japan's difficult relations with the Philippines paralleled Japan's relations with South Korea. As a matter of fact, it ended up taking four years for Japan and the Philippines to conclude the Reparations Agreement between Japan and the Republic of the Philippines, which was signed on May 9, 1956. 
Even after the agreement, relations between Japan and the Philippines were far from amicable. The Philippines also became an ally of the U.S. based on the 1951 Mutual Defense Treaty between those two countries, and even though the Philippines was still concerned about a possible revival of Japan's militarism, the security arrangement with the U.S. was supposed to eliminate such fears (Jacobini, 1961, p. 521). The Philippines were still particularly unhappy about the fact that the U.S. saw Japan as a more significant partner than the Philippines, but accepted it.

Japan first negotiated with the Philippines for diplomatic normalization in a similar stance as it had with Burma. Japan did not negotiate with the Philippines from the position of the defeated even though the Philippines signed the SFPT as one of the victors. The SFPT itself defined Japan as the former occupier of the Philippines, implying superiority. As an ally of the U.S., Japan also expected the Philippines to gracefully implement the wishes of the U.S., which was for the Philippines to be cooperative with the swift recovery of Japan's economy. As a result, Japan's discussions over the reparation issues with the Philippines showed little enthusiasm to atone for the wrongdoings before 1945, despite the gross war damages Japan was known to have caused. Instead, the policy makers of Japan continuously warned the government that Japan should not agree upon an amount that could also deteriorate the economic lives of the Japanese people. The Japanese government also stated that they negotiated with the Philippines without knowing the exact amount of damage Japan caused, which indicated Japan's disinterest in researching what Japan really did to the people of the Philippines under the occupation. Japan rather desired to leave it as vague as possible. 
On the ratification of the reparations agreement with the Philippines, opposition groups such as Japan's Socialist Party said that the agreed amount was too high and Japan was taking a risk of not being able to fulfill the obligation, which would further deteriorate relations between Japan and the Philippines. On the other hand, Japan's Liberal Democratic Party agreed that the amount was high, but stated that it was a good amount to show Japan's sincere remorse.

In the end, Japan agreed to pay the highest amount for the reparations, but relations remained uneasy. Addressing the poor relations, the Joint Declaration between Japan and the Philippines stated that the Philippines' resultant ratification of the SFPT was expected to open up ways to facilitate friendly, respectful, and mutually considerate relations between the two countries. Japan and the Philippines both expected to conclude a treaty of comity and commerce by the near future, but it took another four years to agree upon such a treaty.

The Treaty of Comity and Commerce between Japan and the Philippines finally agreed to on December 9, 1976, stated that Japan and the Philippines desired to maintain and further strengthen friendly relations between themselves, however, the Philippines only managed to ratify it without its Congress' recognition in 1976 (Ikehata \& Yu-Jose, 2003). Retrospectively speaking, the Philippines experienced similar difficulties as Japan having the U.S. presence in their home; however, such similarities were never even recognized for possibly forming solidarity between Japan and Philippines. As the significant other of the U.S., Japan saw the Philippines as only a lover of the U.S., one who should live a humble life before Japan, which of course was not the case. 


\section{Japan- U.S. Relations at Home: The Problems of the Two Patriarchs at Home}

In the late 1940s, Japan's future international life after the occupation did not look promising. Japan thought it would be treated as the fallen defeated former aggressor towards whom no one would be supportive. In contrast, Japan knew who the New Japan was, and based on this knowledge, Japan could accomplish many foreign policy goals in the 1950s. Japan's accommodation to the U.S.' desires enabled Japan to have stable relations with the U.S., which helped Japan to understand others and how to resolve issues with them.

At home, Japan's understanding of the self as the patriarch who protects the future of the Japanese people expected for the U.S. to be the same or even better since the U.S. was Japan's superior other. Albeit in very painfully and tenacious ways, Japan continuously tried to construct the U.S. as the benign superior other of Japan. It is important to note that the authorities of Japan were often challenged by Japanese society and the Japanese people throughout the 1950s, thus, relations between the state-society were not hierarchically well ordered as much as Japan would have consciously or unconsciously desired. The Japanese government faced constant challenges from various groups of the Japanese people, which clearly deviated from the imagined, ideal, hierarchically-ordered world.

The first problem Japan faced in the 1950s was the U.S.' pressure on Japan to rearm so that Japan would contribute to the fight against the communists in Asia. From the perspectives of Japan's understanding of the self and the others, such U.S. pressure was not what Japan would expect from the benign superior other who considers the actual situation of Japan and then guides Japan to make the best decision. It is true that in the 
1951 Security Treaty, Japan agreed to stipulate that: "Japan will itself increasingly assume responsibility for its own defense against direct and indirect aggressions," but Japan apparently was not planning to rebuild its armies in the future (Security Treaty Between Japan and the United States of America, 1951). On the other hand, the U.S. pressured Japan to follow the U.S. strategy toward its allies following the Mutual Security Assistance Act (MSA), which was passed by the U.S. Congress in 1951. According to the MSA Act, the U.S. would provide the military supplies, but also train the allies' officers, so that the U.S. and its allies shared the same strategic visions (Pyle, 2007, p. 234). The MSA document was reminiscent of the 1951 Security Treaty in which Japan promised its eventual military build-up, but again Japan would do so "only to the extent permitted by its general economic condition and capacities." Japan also successfully obtained confirmation from the U.S. that Japan would not be obligated to send its troops overseas (Weinstein, 1971). In addition, Japan obtained new economic assistance from the U.S. through the three other agreements between Japan and the U.S. together with the MSA agreement (Weinstein, 1971). By emphasizing the economic assistance from the U.S., Japan represented the U.S. as the generous and good-willed superior other of Japan who supported Japan's independence.

The second series of events Japan faced were related to the U.S.'s treatment of the Japanese people. Under the occupation, the U.S. mistreatment of the Japanese was what was expected as the miserable consequence of the defeat and occupation. After independence, Japan expected the U.S. to treat the Japanese in the way a good patriarch would treat the rest of the family members. 
The episode known as the "lucky dragon incident" happened on March 1, 1954, when the U.S. conducted a thermonuclear test at Bikini Atoll. The crews of a Japanese fishing vessel were exposed to radioactivity and one of the major Japanese newspapers, Yomiuri, widely reported what happened. This caused an acute decline in the price of tuna because the Japanese people were afraid of radioactive contamination. By September of 1954, one person had already died, and others were suffering from illness caused by radiation. The U.S. was represented as being indifferent to the feelings of the Japanese. The Japanese government again tenaciously negotiated with the U.S. so that the U.S. appeared as if it cared for the lives of the Japanese people. The Japanese and U.S. governments spent almost ten months trying to resolve the issue before finally agreeing on the details of financial compensation to the Japanese victims (Swenson-Wright, 2008).

The U.S. also failed to meet Japan's expectations on issues related to U.S. military bases in Japan. The U.S. and its soldiers enjoyed the privilege of extraterritoriality even after Japan regained its sovereignty. In 1953, the U.S. and Japan at least agreed that any crimes by off-duty U.S. military personnel would be tried in a Japanese court. The intensified anti-bases movements could be seen in the situations surrounding the Tachikawa base in suburban Tokyo. The local residents in Tachikawa increased their opposition to the plan to expand the air bases in Tachikawa.

Japan again faced difficulties in projecting the image of benevolent U.S. who cared for Japan and the people of Japan. On January 30, 1957, it was reported that a U.S. solider, William S. Girard, killed a Japanese housewife who was collecting metal scraps at the U.S. base (Cohen, 2000). It was reported that Girard told the housewife to come close to pick up the scraps, and then suddenly shot her. It was also reported that he meant 
his act as a joke, which outraged the Japanese people. The Japanese government went as far as to compromise justice, promising the U.S. to try him for a lesser crime in return for being able to try him in the Japanese court. Still, the image of the violent and dangerous U.S. evoked by this incident could not be cleared.

Japan tried to restore ideal relations with the U.S. by amending the 1951 security treaty with the U.S. at this time. Kishi served as the Prime Minister from February of 1957 to July of 1960 and called for a "new era of relationship" between Japan and the U.S. Yet, the Treaty of Mutual Cooperation and Security between the United States and Japan signed on January 19, 1960, assured the image of the generous and considerate U.S. as the security provider for Japan. Two major issues were achieved by Japan in concluding this new treaty.

First, the U.S.' obligation to defend Japan was stated in Article V. In addition, by referring to "the constitutional provisions," Japan denied to obligation to participate in collective self-defense in case the U.S. faced external attack outside of Japan. In turn, this meant that the Japanese patriarch made sure to protect the Japanese sons from being possibly corrupted by bonding with the violent father, the U.S. Second, "the prior consultation" on the activities of U.S. forces in Japan was stated in Article VI. By this clause, Japan could now legally communicate its views on U.S. military activities in Japan (Togo, 2010). By this agreement, Japan could make the U.S. look more interested in being sensible to Japan's situations. In return, Japan granted that U.S. forces could use facilities and areas in Japan, which was the same as in the previous security treaty. It took almost ten years, but Japan finally realized the ideal relations between the U.S. and Japan, i.e., the benevolent and considerate U.S. and a liberal, democratic and peaceful Japan. 
Now, the U.S. and Japan "had become partners in the defense not of the Far East, or the Western Pacific, but partners in the defense of Japan [...]" (Weinstein, 1971, p. 101).

\section{The Self, Others, and the World in the eyes of Japan in the 1950s}

Japan's foreign and security behaviors in the 1950s can be understood as an act of realizing the ideal relations between the patriarch and rest of his family members. Japan's identity as a liberal, democratic, and peaceful father who seeks to realize the ideal family relations between the father and the rest of the family prompted Japan to continuously construct the U.S. as a benevolent and caring fatherly figure to the nation of Japan. Throughout the 1950s, Japan's close relations with the U.S. indeed enabled Japan to confidently interact with the USSR, to whom Japan would have had to make more concessions otherwise. Japan's successful negotiations with the USSR enabled Japan to increase its international social status by being able to become a member of the UN, which in return helped increase the respected image from the nation of Japan to the state of Japan. The fact that Japan also could culturally and economically interact with the PRC contributed to making the image of the U.S. as the benevolent guardian of Japan, which again increased respect from the nation of Japan to the state of Japan.

Japan had difficulty constructing amicable relations with South Korea and the Philippines, who both also concluded a bilateral security treaty with the U.S. Japan tried to project its superiority over these two countries, which was fiercely challenged by both of them. Japan failed to resolve any issues with South Korea. With the help of the U.S., Japan somewhat managed to restore diplomatic relations with the Philippines, but the relationship was never amicable. Yet, Japan's adherence to resolve war reparation issues in the form of economic cooperation was supported by the U.S., by which Japan could 
obscure its war responsibilities. This enabled Japan to again construct the U.S. as a benevolent fatherly figure to the nation of Japan, as well as helped to increase the trust between the state of Japan and the nation of Japan, who were relieved and satisfied.

Yet, U.S. behaviors at home contradicted the image of them as the benevolent guardian to the nation of Japan. In the eyes of Japan, U.S. pressures to increase Japan's capability and mobility of the military was contradictory to what was expected of the ideal fatherly figure who should rather try to protect the Japanese sons from bonding with violent patriarchs. Japan patiently, but persistently negotiated with the U.S. throughout the 1950 s and eventually succeeded with the asymmetrical security relations by which only the U.S. was obligated to defend Japan from external attack. At the same time, the burdens of hosting the U.S. bases were transferred to the people in Okinawa (Eldridge, 2008).

Japan made various foreign and security policy decisions throughout the $1950 \mathrm{~s}$, but only the ones that were in line with what the patriarch sees as natural and normal were maintained, and other decisions were continuously attempted to be changed. These processes show that Japan's self-image at home and abroad was powerfully shaped by the patriarch's worldviews. These worldviews functioned as a very strong belief structure without Japan knowing it, thus embodying the unconscious ideologies.

At the same time, how Japan looked at home and abroad was powerfully shaped by the patriarch's worldviews. In the current official discourses, "the people of Japan resolved to build a peaceful and prosperous country," "[Japan] concluded the Japan-US Security Treaty and became a US ally, and then advanced the reconstruction of the country," and "Japan has consistently attached importance to relations with countries in 
the Asia-Pacific region and proactively promoted friendly relationships with and cooperation for the development of developing countries in the regions" (MOFA, 2006, p. 2).

There is nothing untrue about these statements. Yet, Japan's accomplishments came through silencing or quieting the voices of the less socially powerful. The people of Japan were expected to concentrate on making a living instead of participating in various social movements and expressing what they thought was important for them.

The Japanese government had no interest in officially seeking reconciliations with the Asian states to which Japan caused tremendous damage and suffering. At the same time, it was also known that many Japanese also wanted Japan to more proactively express remorse and contrition, which was never realized (Koseki, 2002). Japan also was not interested in bringing justice by trying the suspected Japanese war criminals to see who indeed did or did not commit war crimes or inhumane treatment, or if there were extenuating circumstances. The Japanese government simply wanted them to come home so that they can reunite with their families.

There is no doubt that Japan indeed was in a very challenging situation after the defeat and occupations, when Japan did not even know how to interact with other states. ${ }^{5}$ The ideals and desires surely helped Japan to keep going. Japan fought to rejoin the international community. Japan also fought to avoid any civil wars or the revival of a military government, unlike South Korea or Burma. Japan also accomplished impressive economic advancement. But these ideals and desires simultaneously limited what Japan would have done if it imagined differently or were more conscious about what these

\footnotetext{
${ }^{5}$ See Ryu (1950) for example.
} 
ideals and desires were deemphasizing. And these aspects were a forgotten part of the identity of Japan as proud, liberal, democratic, peaceful, and prosperous. 


\section{CHAPTER 4:}

\section{THE PROUD AND SELF-CONFIDENT JAPANESE MAN}

\section{Introduction}

This chapter explores Japan's identities and unconscious ideologies from the late 1990s to the mid 2000s. This period can be called "the Post-Lost Decade," since the 1990s for Japan is often dubbed "the Lost Decade [Ushinawareta Jūnen]." In the official discourses of Japan during the Post-Lost Decade, it was apparent that the country was in the midst of a serious crisis. At the time, Japan was understood to be a nation state whose sense of pride and confidence had been temporarily eroded, if not completely lost or destroyed. At the same time, Japan was re-imagining itself as a naturally virtuous nation full of excellent potential, and the nation's hardships were blamed on undesirable changes that had come about as a result of postwar economic development.

Looking at the times in their socioeconomic and political context, it is possible to see that popular films during the 2000 s also showed how a proud and self-confident Japan and Japanese people should appear: 1) the competent Japanese salaryman constructed ideal hierarchical relations between the good superior and the good subordinate; 2) delinquent and apathetic Japanese youth should be somewhat punished; 3) foreigners living in Japan should provide comfort to the Japanese people; 4) hardworking Japanese women should be recognized for stepping up and offering strength at a time that others had lost confidence; and 5) dignified and traditional images of Japanese from the past should be endorsed.

In Japanese cinema of this era, Japan's self-identity is familiarized by presenting an ideal world in which Japan's internal others such as women, children, or foreign 
immigrants are willingly obedient to the existing orders, and any identity such as the youth that challenge Japan's traditional value system must be eliminated.

\section{Japan and the Japanese in the Official Discourses}

By the late 1990s, it was evident that Japan's economy had not recovered as much as the nation's government had expected, despite the various economic measures taken during the early to mid-1990s. Social unrest had also increased, and as the dawn of the twenty first century approached, more comprehensive and thorough reform was dramatically and increasingly advocated by Japanese elites. For example, according to Prime Minister Obuchi, who served as Japan's Prime Minister from July 1998 to April 2000, the Japanese people were living in a time equivalent to the Meiji Restoration Era when Japan transformed itself to a modern sovereign nation state, or the post-World War II reconstruction era. During the latter era, Japan's economy "had been reduced to dust," but "the people of Japan resolved to build a peaceful and prosperous country" (MOFA, 2006, p. 2). Koizumi Junichirō became Prime Minister in April 2001 (until September 2006), and he also called for a "Millennium Restoration [Heisei Ishin]."

Unlike the Japan of the post-World War II reconstruction era, the country's contemporary problems did not stem from the embrace of identities from its past. Rather than an illiberal, autocratic, and war-prone Japan, the country was a liberal, democratic, and peaceful country in the Post-Lost Decade. Japan also was proud of the economic prosperity it had achieved since the end of the World War II. A loss of confidence and pride was pervasive, however, in the Japanese society.

The inability to recover fully from the aftermath of its burst economic bubble was only alleviated through the vested interests and social conventions that Japan had built in 
the past. A series of scandals by government officials also augmented the deep sense of disappointment that Japanese people had toward their own society.

The Great Hanshin-Awaji Earthquake of 1995 has typically been cited to show the inadequate abilities of the government to secure the country and its people. Highprofile crimes such as the 1995 Aum Shinrikyo nerve-gas attack on the Tokyo Subway and the 1997 brutal murders of children by a 14 year-old boy were also cited as contributing factors to the anxiety that was present in Japanese society. The education system in general was also blamed for its inability to develop a sense of respect for Japan's history and traditions, especially among the country's youth. Other problems that caused despair and pessimism about the future included an aging population, low birth rate, women's inequality, and a seemingly defunct social welfare system.

Economic recovery and maintaining the identity of a prosperous nation were among the most important goals for the Japanese government. Japanese intellectuals at that time argued that Japan should ceaselessly work to reform itself and that a New Japan must embrace various identities in order to maintain prosperity. Japan needed to be creative, competitive, independent, and have a pioneering spirit, as well as a highly developed level of science and technology. They also argued that gender equality should be advanced further, and that more immigrants must be accepted into the country. The paternalistic and top-down relations between the government and its people in the past were no longer seen as desirable in a twenty-first century democratic Japan. The new Japanese government was expected to be increasingly competent and confident. It was to create and enforce laws, promote a secure society, and protect the lives and property of the people of Japan. Upholding its responsibility was a path to recover the trust from its 
people and confidence in the nation. As such, the government was expected to carry out its duties in a professional manner that would make the Japanese people confident and proud.

At the same time, many of Japan's social issues could also be understood to be the result of the loss of the country's traditional values. Japan had to be moral, thus the identity of a dignified Japan had to be reestablished. The myopic pursuit of monetary gains, the collapse of the local community structure, excessive selfishness, and disrespect for the Japan's own past culture and history were all understood to be the result of rapid economic growth since the end of World War II. Conservative Japanese intellectuals at that time called for Japan to recover the values it had lost in the preceding sixty years. Prime Minister Obuchi (1999) said in a policy speech that Japan must be a "moral [country] enriched with great aspirations." He also stated that "our society should be one in which we are friendly to others, and in which we all naturally see the beauty which surrounds us for what it is, caring about our neighbors, building regional communities in which we can live at ease" (Obuchi, 1999). Japanese youth must also have "compassion for others, a spirit of dedication to the betterment of others, respect for the cultural and traditions of our nation and other elements of what it takes for us to be rich in spirit as Japanese, as well as the fostering of principles and ethics" (Obuchi, 1999). In summary, policy makers faced the dilemma of where to start when facing so many social problems.

\section{Cultural Responses}

Films during the Post-Lost Decade offer popular narratives for how the Japanese people at that time should behave in certain contexts. The competent but humble Japanese salaryman was expected to recover a safe Japan through various actions. Youth 
who challenge authority were to be severely punished to prove that embracing traditional values is the better choice. Japanese women, while still domesticated, were increasingly visible in the workplace. Foreigners were expected to be obedient to Japanese social strictures. A respect for traditional Japanese customs and history was also celebrated.

\section{The Ideal Japanese Sons at Crisis}

The Post-Lost Decade Japan inhabited a world in which dangers were everywhere. Japan faced various threats to its society ranging from crimes (as seen in Bayside Shake Down (1998) and Bayside Shake Down 2 (2003)), large-scale accidents (as seen in Umizaru (2004)), terrorism (as seen in Whiteout (2000) and Aegis (2005)) and environmental disasters (as seen in Japan Sink (2007)). Bayside Shakedown originally was a dramatic television series that aired eleven episodes in early 1997. Due to the show's popularity, after it ended several other related series and feature films were produced. Bayside Shakedown was the first movie thereafter and was quite successful for a Japanese live-action film. Bayside Shakedown 2 surpassed that success and set a boxoffice record. Umizaru and Limit of Love: Umizaru (2006) (referred as Umizaru 2 hereafter) were adaptations of a comic with the same name. An abundant supply of Bayside Shakedown and Umizaru related visual cultural products indicated not only that these two series were popular, but also that they were continuously consumed through different outlets.

The saviors in these films are all middle-class, white-collar Japanese men who work for companies or governments. They are the so-called "salaryman" in Japanese. These saviors however are different from the international businessmen who supported 
Japan's economic development. They are a new type of salaryman: the Post-Bubble, Japanese, middle-class employees for companies or governments.

Not only did the ideal Japanese sons and middle class salarymen contribute to the public safety of Japan, but they took steps of extraordinary heroism in Japanese popular films. They protected Tokyo from a terrorist attack in Aegis, rescued trapped people from large-scale accidents in Umizaru 2, and even saved Japan from sinking under water in Japan Sink. In official discourses, the safety and the security of Japan and its people were significant factors in constituting a proud identity where Japan was the world's safest country. Any events that disrupt the safety and the security of Japan and its people were seen as tests of the authorities' credibility.

As Ryan and Ryan and Kellner (1990) note with the disaster films, the format of the story is quite simple. Peace or order is disrupted by accidents, disasters, or external attacks, but is restored by the saviors. Still, there are two important characteristics that are shared by these films.

First, these films confirm Japanese anxieties in the Post-Lost Decade. In the world of these popular films, top national leaders such as politicians and high-ranking bureaucrats are not of much help in responding to disasters or crises. Often these elites are depicted as selfish and inflexible, giving priority to their own narrowly defined interests. These elites rarely break rules and regulations, even though doing so would be the appropriate action under certain circumstances. Second, the saviors are young, middle-class Japanese salarymen who happen to be present where the disasters or external attacks occurred. They had little choice but to respond to the situations they faced. Thus, their acts are essentially self-defense. Each man mostly acts by himself or 
with only a small amount of help from his close superiors or colleagues. The men are professional, humble, and selfless, compelled by their own sense of duty. Third, and related to the first point, these saviors bond with good superiors, who at least understand the problems the saviors face and sometimes even take a risk implicitly or explicitly by trusting the saviors to handle situations under their discretion. The good superiors trust their own superiors, unlike the bad superiors, who are too selfish and inflexible to authorize measures or actions that may infringe upon the existing rules and codes. Thus, the realization of the secure Japan by saving Japan from crisis is equated to the ideal bonding between the good superior and the good subordinates.

Surprisingly, these young middle-class Japanese salarymen are seen as highly competent. For example, in the film Aegis, the protagonist successfully repels highlytrained terrorists simply because he knows a lot of information about the hijacked vessels. He does not receive any help from the military or police. He saves Tokyo by himself with only the aid of his young colleague. In Japan Sink, the protagonist saves Japan simply because he knows how to operate a special submarine. In Umizaru 2, the protagonist is a trained rescue diver, and he and his partner become trapped inside a fire filled vessel that is about to explode. Due to the critical situation, his superior is unable to send assistance, and the diver alone must save his partner and two other civilians who are trapped inside. In this very challenging situation, the protagonist successfully rescues the others without casualties.

Bayside Shake Down and Bayside Shake Down 2 are comedic films about a detective salaryman. Detective Aoshima represents an ideal Post-Bubble Japanese man who no longer seeks monetary success and gives up his successful career as a salesperson 
at a computer company. Instead, he seeks to contribute to Japanese society and becomes a police detective. He is hardworking, flexible, and creative, but unable to properly conduct his investigations due to workplace factionalism, red tape, and territorial issues perpetuated by higher authorities within the police organization. In the films, those organizational problems are underscored as Detective Aoshima and his colleagues work to solve criminal cases.

What makes Detective Aoshima ideal is not that he aggressively seeks change in the police organization, but that he is very humble and thoughtfully approaches the problems he faces. Detective Aoshima simply believes that he could do more good for Japanese society if there are fewer organizational problems. At the same time, Detective Aoshima despairs that such change will not happen easily. Detective Aoshima finds out that Mr. Muroi, one of his superiors, also understands the obstacles local detectives experience. Yet, Mr. Muroi is not in an influential position either since he does not belong to any of the strong factions within the organization, such as the group of Tokyo University graduates. Mr. Muroi is from a less prestigious university and must be competitive in order to be promoted to a position of power that may eventually bring change to the police organization. The friendship that develops between the two men is based on their mutual frustration at not being able to do what they believe is best for all their cases. Mr. Aoshima even takes risks when it comes to settling a case that may benefit Mr. Muroi's future. Mr. Aoshima often ignores the orders and rules from his superiors. He delivers results, but is punished for his disobedience.

These films portray the ideal Japanese son who is competent, creative, caring and works hard, but not for monetary gain or notoriety. Detective Aoshima merely hopes for 
change by supporting Mr. Muroi. All the ideal Japanese son needs is a small amount of hope and a trusting superior.

\section{Dangerous and Self-Destructive Troubled Youth}

Although some films depict the younger generation a competent, loyal, and selfless group capable of restoring Japan, other films focus on delinquent youths as a source of panic and anxiety. To ameliorate the sense of anxiety, these films 1) confirm the validity of the anxieties; 2) suggest ways to eliminate dangerous youths; and 3) provide for an alternative solution to the original problem.

The first point is well articulated in the film All About Lily Chu-Chu (2001) directed by Iwai Shunji, who is known for his profound and beautiful screen imagery. The story is set in the present in a beautiful suburban area surrounded by green fields, which represent the peace and beauty that Japanese traditionally valued highly. In contrast to such beautiful landscapes, the film shows young delinquents who are involved in brutal bullying. The adults close to the situation, including parents and teachers, do not seem to be interested in addressing the problem. As the story develops, the bullying only gets worse until a tormented student kills one of the bullies in a crowd. The police are unable to identify the suspect, and the bullied student resumes his normal life. The only ramification is a decline in his school performance. As with the official narratives, this film blames delinquency on the loss of traditional community and family values. Delving into the pains and frustrations of the bullying and the bullied youth, the film suggests no clear remedy and evokes feelings of despair. Presumably, however, the film supports efforts by Japanese politicians of the era to promote educational reform while increasing punishments for juvenile crime. 
Battle Royale (2000) directed by Fukasaku Kinji takes a different approach and tries to find alternative ways to cheer up the Japanese people worrying about the phenomenon of dangerous youth. Battle Royale was certified R-15 by the Japanese Board of Classification, making the film restricted for those under the age of 15 , so clearly the film is meant not to be seen by or to influence young people. Fukasaku Kinji, known for the famous series of Yakuza Films in the 1970s (Battles without Honor and Humanity (1973)), was no stranger to intense screen violence and skillfully showed students killing each other in a somewhat humorous and absurd fashion. Once the focus is temporarily taken away from the severe violence the film displays, it is possible to see how the story in fact offers a typical moral tale that comforts viewers.

The story of Battle Royale takes place in a dystopian Japan where adults have lost all confidence due to their social and economical failures. In the film, Japan has passed a law called the BR Act, which selects a group of junior high school students and forces them to battle to the death until only one survivor is left as the victor. The students in the film exhibit behaviors seen as typical of juvenile delinquency. They boycott classes, do not follow rules, and disrespect their teachers. Their self-destructiveness is channeled towards one another, so bullying is not uncommon. Yet, these students are not absolutely evil. The protagonist, a young Japanese boy, narrates that the students are just managing their grim, everyday world in the best way they can.

The fate of the students suddenly changes in the film when they abruptly learn that they have arrived at a deserted island and have been chosen to battle each other. The former teacher whom they used to disrespect even comes back to supervise the battle. The students in the film adjust themselves to the situation, unleashing their potential. As 
Allsop (2003) points out, they do not always stick to traditional values such as modesty, self-sacrifice, sympathy, or teamwork. Yet, some of the students are very competitive and creative. The more technologically-advanced boys cooperate with one another and nearly succeed in hacking the main computer to prevent authorities from continuing the killing game. One female student sees the battle situation as an opportunity to express her hateful feelings and kills her friends and classmates. One couple simply decides to jump off a cliff together and die that way. Some girls form a community and try to find a solution together, but are unsuccessful.

The film shows that Japanese can be creative, competitive, and individualistic, but tapping such potential for the youth may not always yield a desirable outcome. To solidify this point, the film's two last survivors are the only ones who actually embrace traditional Japanese values. The protagonist male student maintains his dignity by using force during the game only in self-defense. The female survivor is a typical feminine Japanese figure whom the protagonist, and sometimes the supervising teacher, secretly desire to protect. The male protagonist in the end kills this teacher, who was holding the female student at gunpoint. Shortly afterwards, they learn that the teacher's gun was actually a toy made of plastic, raising moral questions about the male protagonist's act that challenged the teacher who was working to realize a hierarchically ordered world. These students successfully escape the island, but are unable to change the world and stop the battles from continuing in the future. In the end, they are named wanted criminals by the Japanese authorities. Battle Royale suggests that young Japanese are dangerous because they are full of potential that could in fact be used for the wrong causes. Therefore, they must be disciplined. Once again, Japan does not know how to 
come terms with young people who may challenge the existing hierarchical orders. Battle Royale only offers suggestions for what Japan should not do.

The film Go (2001), on the other hand, simply depicts what Japan desires to see: the positive transformation of a violent youth who is able to mature over time. Unlike many other films that depict the lives of the Korean Residents in $\operatorname{Japan}^{6}$, Go was well received for successfully portraying a likable image of Korean Residents.

The protagonist in Go, Mr. Sugihara, is a second-generation Korean Resident living in Japan and a native speaker of Japanese. He even enjoys Rakugo, a traditional form of Japanese comedy. Mr. Sugihara is not good at studying, but is very good at street fighting, thus embodying a typical image of Korean residents in Japan. Mr. Sugihara has an unconventional but very caring father who is a former boxer and who taught his son how to protect himself. When Mr. Sugihara is taken to the police for participating in a street fight, his father severely beats him. This arouses the sympathy of the police officer who decides to release Mr. Sugihara. The father also changes their nationality from North Korean to South Korean in hope that it would make Mr. Sugihara's life easier. In general, Mr. Sugihara is a less fanciful example of troubled Japanese youth than those depicted in As the story develops, Mr. Sugihara starts courting a Japanese girl, but is rejected when he reveals to her that he is Korean. The Japanese girl tells him that her father does not want her to date Korean or Chinese people. Mr. Sugihara also faces the hardship of the death of his best friend, another Korean resident who is stabbed to death when he tries to stop a Japanese man who from harassing a girl in traditional Korean clothing. Experiencing the discrimination of Japanese society troubles Mr. Sugihara, but he

\footnotetext{
${ }^{6}$ See Yang (2002), for example.
} 
decides not to take it personally. Instead, he devotes himself to studying for the Japanese college entrance exams, and thus assimilates into a Japanese life style.

\section{Ideal Japanese Daughters}

The Japanese daughters portrayed in popular films of the new millennium made the Japanese women feel good about themselves (just as Mr. Sugihara had done for Japanese of Korean descent) while also uplifting the temporarily humiliated Japanese man through their displays of hard-work and successful struggles. Instances of the good Japanese unmarried daughter paired with a weak Japanese man are ubiquitous in popular Japanese films. Examples of such relations are Chihiro and Haku in the film Spirited Away (2001), Asuka or Rei and Shinji in the Evangelion (2007) series, Sophie and Howl in Howl's Moving Castle (2004), Reiko and Onodera in Japan Sink (2006) and Shizuku and Takumi in Be With You (2004). None of these female characters suffer from a lost sense of confidence and pride, but the male characters around them do.

Spirited Away set the box office record in Japan and as of 2014 is still the most watched Japanese movie in history. Spirited Away separates itself from the other films mentioned in this chapter by holding the distinction of being the first animated film to win the Golden Bear Award at the Berlin Film Festival. It also won the 2003 Academy Award for best animated film. This international recognition of Spirited Away made director Miyazaki Hayao one of the best-known Japanese film directors, on a par with Akira Kurosawa.

Spirited Away presents an interesting but somewhat nostalgic world that is beautiful and filled with attractive mythical creatures. It tells the story of a ten-year old female child who becomes enslaved in this magical world and who years to return to her 
former life in an upper-middle class family. Chihiro works hard and helps the boys feel better about themselves as if that were her proper role as a young Japanese female. Her transition to servitude is caused when she tries to rescue her parents, who represent Japanese with a lost sense of morality and are transformed into pigs after dining at an empty restaurant without permission. A witch who has the power to undo her parents' spell tells the daughter she will have to work at a bathhouse for Japanese deities in order to get her parents back. She agrees and signs a contract.

In this world, Chihiro is not welcomed because she is a minority considered inferior by the mythical creatures. She also appears to be incapable of doing her job properly. She is docile, honest, and hard working, but not money-driven. In the beginning, she lacks the basic skills that Japanese society typically expects good children to possess, such as proper etiquette and cleaning skills. Despite everyone's negative expectations, she learns the necessary skills quickly, demonstrating her natural ability. She is also gentle to the point she is the only one to help an extremely filthy deity that the witch and all the other workers initially thought is so evil that he could not be purified. It turns out that the deity was filthy due to an injury, and by healing him the daughter proves her usefulness and brings fortune to the witch. The daughter again proves her usefulness to the witch's business when she is also the only one in the story able to tell that the seemingly generous customer No-Face had been actually using fake money to pay.

The daughter proves herself at work thanks to her abilities, but she never becomes arrogant. As the story develops, her other caring and unselfish qualities begin to shine through. She saves a dying boy's life by feeding him a special medicine that was a gift 
from one of her happy customers even though she had been planning to use the medicine to save her parents. She also corrects the boy's misdeeds by returning a magical seal that he had stolen from the witch's twin sister, and she helps the witch's adult son who looks like a baby and who represents spoiled Japanese youth. As she allows him to accompany her on the adventure, he learns how to be independent. By simply following her heart, Chihiro accomplishes many good deeds, but she does not challenge the existing order. In the end, she is allowed to go back to her world with her parents, but the world of mythical creatures where she was enslaved remains unchanged. The witch still runs the bathhouse and the workers are still there. The film also emphasizes that its story is not of a girl growing up. To make that point clear, Chihiro loses her memories of the other world upon returning to her original home.

The film Spirited Away perfectly depicts expectations of the ideal Japanese female. She is likable for her feminine qualities, and idea reflected in other films of this period. In Be With You, the protagonist decides not to go against her fate even though that means she will die six years after marrying her high-school sweetheart and bearing a son. Unlike the films of the 1950s, many contemporary female characters have various occupations. Asuka in Evangelion pilots a fighting robot, Reiko in Japan Sink is a firerescue worker, and Sumire in Bayside Shakedown is a detective. Yet, most of the time these women remain in supportive positions and contributed to the eventual success of a male character.

\section{Traditional Japanese Family and Traditional Japanese Neighbor Relations}

Always: Sunset on Third Street (2005) (referred to as Always hereafter) and Always 2: Sunset on Third Street (2007) (Always 2) provide typically nostalgic and 
sentimental representations of the Japanese family during the late 1950s when Japan was about to enter a high-growth economic period, signified by the completion of the Tokyo Tower. The promises made in Always and Always 2 are that the Japanese people at that time were not economically wealthy but were energetically and tenaciously living their own lives.

The Always films focus on two families. Mr. Suzuki's household consists of Suzuki Norifumi, the father and owner of a small car repair center, his wife Tomoe Suzuki, and their six year-old son Ippei. Mutsuko, a high-school graduate from the countryside of Japan and herself one of six daughters to a large family, joins Mr. Suzuki's family as his assistant. The family in the sequel consists of Chagawa Ryūnosuke and his six year-old son Junnosuke, who Mr. Chagawa reluctantly adopts as a single father. Mr. Chagawa is a graduate of Tokyo University, one of the best universities in Japan, but is an unsuccessful writer.

In these films, Mr. Suzuki and Mr. Chagawa are both dreamers. Mr. Suzuki is confident about his eventual success as a car manufacturer, and Mr. Chagawa keeps sending his works to publishers in hopes of becoming a critically acclaimed writer. The films are not about the success stories or the accomplishments of these two men, but rather are a celebration of the processes of their vibrant everyday lives.

The benign and amicable relationship within the families, as well as between neighbors, is a reminder of the virtuous quality of the Japanese during the time of these films. The goodness of the Japanese people is reaffirmed at a time when this ideal seemed to have been forgotten amidst rapid economic growth. The message is that these two fathers only had to try their best to succeed and remain true to themselves. Their families 
and neighbors loved and supported the fathers. Mr. Chagawa is contrasted with Mr. Kawabuchi, a successful businessman and birthfather to Mr. Chagawa's adopted son. Mr. Kawabuchi recognizes his son's academic ability and insists that his son deserves a better environment for developing a successful career in future. Mr. Chagawa reluctantly agrees and urges his adopted son to go live with his birthfather. His adopted son however chooses to remain with Mr. Chagawa. ${ }^{7}$

Mr. Chagawa shows a path for becoming a moral Japanese man without having economic success by completing his family and doing his best to be a breadwinner for his adopted son. Mr. Chagawa concentrates on finishing his new novel and hopes to receive a prestigious award that would enable him to make enough money to support his family. He fails, but his effort is ultimately rewarded. Unlike Mr. Kawabuchi, who shows no interest in taking care of his ex-mistress and birthmother to Junnosuke, Mr. Chagawa marries Hiromi, a former barmaid who became a stripper in order to pay off her father's debt. Upon Hiromi's return, Mr. Chagawa completed the traditional Japanese familythe father, wife/mother, and their adopted son-all of whom love and care for one another irrespective of their economic situation, blood relationship, or class differences.

The roles of children in achieving the Japanese moral order within the family are striking in these films. ${ }^{8}$ Junnosuke is an ideal child who simply wants to be with his stepfather. He even skips a school lunch to try and help his family due to their tight

\footnotetext{
${ }^{7}$ In another critically acclaimed film, Japan's Tragedy [Nihon no Higeki] (1953), a twenty-somethingyear-old son of a struggling mother who has worked as a barmaid to raise her two children chose to be adopted into a wealthy family, despite his birthmother's pleads not to do so. The mother kills herself in the end.

${ }^{8}$ In the film Tokyo Story (1953), a young child is represented as selfish and materialistic. The son exhibits no respect for his father. Even his grandparents complain about sharing a room with the other visiting grandparents.
} 
economic situation. Junnosuke also is a reason for Mr. Chagawa to want to become a breadwinner. Similarly, Mr. Suzuki is taking care of his niece Mika to help out since her father's business collapsed. The niece previously enjoyed materialistic wealth, but had to adjust to a more humble life within Mr. Suzuki's home. As the story develops, Mika learns how to be a caring daughter and eventually reunites happily with her father.

Always and Always 2 offer a popular narrative for the Japanese man who has lost confidence in himself and fails to maintain economic security, but still is moral. These stories suggest that what Japan needed in the Post-Bubble era was character and resolve. At first blush, this might seem contradictory considering the Japanese government had always given first priority to overcoming economic stagnation, emphasizing individuals' competitiveness and creativeness. But popular imaginary emphasizes that the virtue of resultant unity among the family members and the neighbors rather than economic success. In these films, when a Japanese man puts forth his best effort, he wins approval from his family and neighbors. The celebration of the humble life also suggests that people should be less demanding of public assistance. These films portray members of Japan's economic underclass as benign, but also as independent and willing to help one another. Such a construction of the morally good working poor was vital to the Japanese government, which had implemented several economic policies that would increase the gap between the rich and the poor and must have been worried about how the poor would react.

\section{Japanese Fathers and Sons at War}

Japanese war movies such as Yamato (2005), Lorelei (2005), and For Those We Love (2007) also achieved considerable success in the 2000s. According to Shimazu 
(2003), Japan in the 1980s showed little interest in cultural products whose main themes were war. In the 1990s, renewed debates over Japan's war responsibilities seemingly led to an increase in cultural products related to Japan's wars, mostly documentaries, dramas, and TV programs. Yet, the debate over the Japanese as victimizers or victims remained highly controversial to say the least. There was no consensus on how to come terms with the past for Japan.

Unlike the silence in the 1980s and the struggles in the 1990s over Japan's proper identity, the films of the new millennium offer a very clear and straightforward answer to the problem of Japanese self-doubt. These films look to recover the narratives of the past in a way that reinforces contemporary Japanese pride, while leaving out problematic aspects of the past.

Although its intended audience is contemporary, peaceful Japanese, the narrative in the film For Those We Love is told mostly from the viewpoint of an old Japanese woman who is known as the "mother of Kamikaze pilots." She once ran a restaurant near a military base where Kamikaze Pilots trained and deployed for missions. The story of Lorelei, in contrast, is told by a present-day Japanese writer. And the film Yamato (2005) blends the two perspectives by focusing on a young Japanese woman Uchida Makiko, who is the daughter of a survivor of the Yamato battleship. She goes to look for the place where that ship had sunk in hopes of seeking reconciliation with her now deceased father, with whom she had a difficult relationship. She accidentally meets an old man who served with her father on the Yamato. The film presents young Japanese soldiers as having fought bravely, although they knew the chances of survival were slim. Uchida learns how good and brave her father was, but also that the survivor she met suffered 
from a sense of guilt because he survived while his friends did not. Juxtaposing the present and the past, films such as this ask contemporary Japanese to think about those who sacrificed themselves for the nation in the past.

These films manipulate Japan's understanding of World War II by disproportionally focusing on the battles between Japan and the U.S. between 1941 and 1945. They generally ignore Japan's colonization of Korea for 35 years and Taiwan for 50 years, as well as the state of war that existed between Japan and China from 1931 to 1945. Omitted are the voices of non-Japanese victims of World War II, unlike 1950s films such as Human Conditions that did include stories of Japan's brutal treatment of Chinese and Korean people during World War II. Excluding the viewpoints of Asian neighbors is made possible by the choice not to portray any Japanese sons in Southeast Asia, Korea, or China. The Japanese sons in For Those We Love (2007) and Yamato (2005) are Japanese nationals living in Japan. The narrative in Lorelei takes place mostly inside of a submarine that is isolated from the outer world.

Japanese war films of the new millennium also show how to come terms with the Japanese fathers who were directly or indirectly responsible for sending the Japanese sons to the battlefields. The characters in both Lorelei and Yamato are uncomfortable with the practice of mobilizing young Japanese men in battle. In Lorelei, the captain of a submarine allows his subordinates to choose whether to go with him for a suicidal mission in order to stop a planned nuclear attack on Tokyo or to go back to Japan for the anticipated post-World War II reconstruction of the country. The captain also apologizes to his subordinates for the actions of Japanese fathers who started the war and compelled 
their sons to fight it. The captain finds out that more of his subordinates decide to go home than stay. He expresses slight disappointment, but respects their decisions.

These popular films reflect the delicate balance between the desire to feel secure (by trying to confirm that Japanese soldiers sacrifice themselves when they must), and knowing that young Japanese men do not have to die meaningless deaths. Perhaps this is the reason that For Those We Love did not enjoy the same commercial success as both Yamato and Lorelei. In For Those We Love, the ideal Japanese sons are the ones willing to sacrifice themselves. Thus, the traditionally imagined Japanese mentality of selfsacrifice is presented as the value Japanese youth should possess. For Those We Love also emphasizes that it is important to remember that the self-sacrificing sons of the past are the ones enshrined in Yasukuni-Shrine.

Understanding past ideals of Japanese youth may reinforce contemporary representations of the post-World War II generation as compose of "spoiled brats." Lorelei somewhat challenges this representation and instead explores the idea that the mistakes of the former generation should not be passed on to future generations. Lorelei also consciously questions the Japanese who were directly responsible for World War II, even musing about whether Japan's leaders planned for Tokyo to be bombed with nuclear weapons in order to kill the Japanese responsible for World War II. At present, a moral Japan is possible only if the fathers stop passing the blame of the war on to the next generation. In return, the younger generations are allowed to have a future with security and economic prosperity so long as they do not repeat the mistakes of the past.

How do contemporary Japanese who suffer from low self-confidence understand the Japanese fathers and the sons of the wartime era? The meaning of war remains tragic 
and sad, but good fathers or good superiors, as Lorelei or Yamao showed, at least care for Japanese sons and the Japanese soldiers and desire to spare their lives if possible. Still, war only ends when young Japanese soldiers reject these caring but violent fathers. What the Post-Lost Decade Japan and the Japanese should remember, these films suggest, are the narratives and the good Japanese of the past.

\section{The Self, Others, and the World in Japan's Eyes in the 2000s}

Contemporary Japan understands itself through narratives for the recovery of its sense of confidence and pride in the Post-Lost Decade. In the popular cinematic imagination, ideal Japanese sons bond with good superiors and dissociate themselves from bad superiors. Good superiors are typically imagined as men who understand and share the pains and struggles of their Japanese sons. Good superiors also do not strictly control Japanese sons. Instead, they trust the sons and let them exercise their capabilities autonomously. On the other hand, bad superiors only care about their own self-interest yet are more powerful than the good sons and good superiors. Bad superiors in the past were associated with violence, tragedy and even death. However, the ideal sons refrain from using any violence whenever possible.

There are also alternative paths to recover the sense of confidence and pride of the Japanese. Women, children, and foreigners in general must display their obedience to Japanese men who temporarily suffer from a lost sense of confidence and pride. Ultimately, hierarchy must be restored for Japanese men to regain their confidence. 
CHAPTER 5:

\section{RESTORING THE PROUD AND SELF-CONFIDENT JAPAN}

\section{Introduction}

Japan's behavior during the Post-Lost Decade can be best understood as representing Japan's conscious and unconscious desires to restore the imagined ideal order. Irrespective of what Japanese officials wished or decided to do, Japan's foreign and security policies ended up being significantly shaped by ideal images of the self and of the outside world derived from the analysis of popular films in the previous chapter.

Japan preferred to construct amicable relations with the U.S. through strengthening an alliance much in the same way that ideal Japanese sons bonded with their good senior partners. At the same time, Japan did not always prefer to be cooperative with the U.S., also much in the same way as ideal sons kept their distance from violent and authoritative superiors.

Japan also wished to construct amicable relations with other Asian states as a principle for Japan's foreign and security policies. Japan projected its power over its neighboring countries in the same way that the Japanese sons whose sense of confidence and pride had been temporarily eroded interacted with other people who helped, supported, and obeyed the Japanese. Japan preferred to construct amicable relations with South Korea in the way that Japan helps and adores South Korea. In return, South Korea would respect and follow Japan's wishes. Japan expressed a will to improve relations with North Korea, but ended up constructing confrontational, albeit stable relations. 


\section{Japan's Foreign and Security Policies in the 2000s}

Japan's understanding of the self, others and the world in the Post-Lost Decade for domestic matters also parallels their understanding of the self, others and the world in the international arena. By the late 1990s, it was clear that the high-profile international events Japan faced throughout that time served only to increase Japan's sense of insecurity.

Japan's response to the Gulf War was criticized as "too little, too late," and was often cited as a source contributing to Japan's distrustful and dishonorable image in the international community. Japan's relations with the U.S. were also deeply troubled, marred by intense friction over trade. The U.S. openly criticized Japan as an unfair country, which "started to erode the very core of the alliance, mutual trust" (Funabashi \& Council of Foreign Affairs, 1999, p. 446). North Korea's ambitious steps to develop nuclear weapons, their missile tests, as well as suspected spy ship activity within Japanese territorial waters, were all understood by Japan to be signs that the U.S. - Japan security alliance was of questionable credibility. The fierce rivalry between Japan and the U.S. gradually toned down as Japan's economic recession continued, but it was agreed by Japanese officials and intellectuals that their country had to work on improving relations with the U.S.

Japan's relations with South Korea and China were no better at the time. Japan had been criticized since the 1980s for its lack of remorse for wrongdoings committed during the days of Great Imperial Japan. During the 1990s, the issue of comfort women outraged Japan's Asian neighbors. The Japanese government issued official apologies for the wrongdoings of Great Imperial Japan. They also issued a formal apology to comfort 
women and created a private foundation that provided monetary compensation. Nevertheless, these measures were criticized as insufficient and insincere, which further contributed to Japan's being distrusted and dishonored in the international community.

The Japanese government wished to improve these situations, which threatened the security of Japan Self. The Japanese government continuously stated that friendly and close relations between Japan and the U.S., as well as other Asian countries, must be forged and maintained, mostly because a prosperous and dignified Japan was only possible if they had a stable international order. I will now demonstrate how the ways in which Japan tried to secure or insecure the self are shaped by Japan's understanding of the self, the others, and the world that is, in fact, derived from Japanese cinematic identities.

\section{Japan - U.S. Relations: The Ideal Japanese Son and His Senior Partner}

The Japanese government maintained its official position making the U.S. the most important country for Japan to have as an ally. Japan's relations with the U.S. also served as the foundation for Japan to interact with other countries; therefore, the stable meaning of the self in relation to the U.S. was crucial for Japan's own security. Japan understood the self as the competent junior partner of the U.S., rather than merely a subordinate or satellite. The Prime Minister Koizumi, for example, stated that:

Looking back ten years ago at the Bubble Period, it appears to me that Japan was enveloped in a sort of over confidence. Despite the fact that the total landmass of our nation is less than the state of California in the United States, the assessed value of Japan's land exceeded that of all 50 states combined. Japanese corporations purchased buildings in the United States. They bought hotels. They 
bought golf courses. The yen appreciated. We were on a roll. It seems to me that we were overconfident. (Koizumi, 2002)

During the Bubble Period, the image of Japan as a competent and wealthy international businessman was effectively invoked and used to show how inappropriate Japan was in relation to the U.S. Japan acted as if it was much more powerful than the U.S. by trying to exercise its economic power. Yet, Japan had been overconfident in the near past, and even though there had been a lost sense of confidence, Japan believed itself to still be competent and greater than many other states: "Now, ten years later we have, conversely, lost our confidence. I believe that Japan still has great latent potential. If you compare Japan to many countries it is clear we have sufficient latent potential" (Koizumi, 2002).

The Japan Self recognized the power of the U.S., but at the same time, the Japan Self recognized its own power over states other than the U.S. Having confirmed this type of hierarchical relations between the two nations, the Japan Self saw the bonding between the competent, humble, and humanitarian Japanese sons and the trustworthy and considerate senior partners not only as ideal, but also as crucial to improving the sense of insecurity. The Japan Self also saw any associations between the ideal Japanese sons and the authoritative, selfish, and/or physically violent superiors as dangerous, although such superiors were still a crucial part of the world.

\section{Japan's Security Decisions and tamed Hawkish and/or Liberal Dreams}

Japan made several successive security decisions that many specialists and professional analysts of Japan found to be quite a new phenomenon. Yet, none of these security decisions led Japan to be able to exercise the right to belligerency or collective 
self-defense, nor to be able to join military operations authorized by the United Nations Security Council (UNSC). Instead, these decisions dissociated Japan as much as possible from the use of force, expanding its role in non-combat missions, all the while maintaining the closest possible relations with the U.S., in much the same passive fashion as the ideal cinematic Japanese sons.

In December of 1998, Japan announced that it would initiate joint research on the Ballistic Missile Defense with the U.S. shortly after North Korea conducted a missile test. At the same time, Japan also announced that they were to develop information-gathering satellites (IGS) so that Japan could monitor any activities that might threaten their security. Japan had refrained from such actions for a long time because they might breach Japan's policy regarding the peaceful use of outer space (Oros, 2008, p. 139). In April of 1999, Japan passed the law for situations in surrounding areas called the "Act on Measures to Ensure the Peace and Security of Japan in Perilous Situations in Areas Surrounding Japan,” which allowed for Japan's Self Defense Forces to provide backup support to the U.S. in the event of a contingency. Yet, their tasks were limited to noncombat missions, therefore, the law did not constitute an act exercising the right to collective self-defense (Hughes, 2004).

There were some practices that could have violated what was considered acceptable behavior in the past. In March of 1999, Japan's Coastal Guard (JCG) fired a warning shot towards an alleged North Korean spy ship. In December of 1999, the JCG encountered an unidentified ship and fired shots at it. The ship was sunk and later confirmed to be a North Korean spy ship. Those were the first cases of the JCG using weapons to protect Japan's security. The JCG's actions constituted acts of self-defense 
that were permissible under Japan's constitution. Yet, the use of weapons is not an easy choice for the JCG, and these responses have remained rather rare. In 2002, the "Act on Cooperation with United Nations Peacekeeping Operations and Other Operations" was revised, now allowing SDF members to participate in the missions by Peacekeeping Forces (PKF). Yet, the conditions for them to be allowed to use weapons were severely limited. At least within the legal framework, Japan did not seem to be interested in developing combat abilities.

\section{Japan and the Belligerent but Considerate Senior Partner: the U.S.}

The legal frameworks discussed above are in line with what is to be expected of Japan's cinematic identities. Yet, Japan's actual responses to U.S. military operations in Afghanistan and the Iraq War serve as good tests to see if the real world parallels the "reel world" so to speak.

These cases are particularly interesting for several reasons. First, the leader of Japan at the time, Prime Minister Koizumi, enjoyed unprecedented popularity among the Japanese people. He personally believed that Japan's constitution should be revised so that Japan could engage in acts of collective self-defense, particularly in relation to Japan's ally, the U.S. He also believed that the SDFs should be properly recognized as Japan's military so that Japan could show a determination to defend its homeland to the world. Koizumi also visited the Yasukuni Shrine every year, which was often considered a sign of being part of a right wing political group in Japan. Second, the terrorist attack against the U.S. on September 11, 2001 and the military responses of the U.S. thereafter, were not something that had been imagined yet within Japan's legal frameworks. Japan had still to explore what the appropriate behaviors for Japan were under such situations, 
and to continuously evaluate and adjust based on its understanding of the self, others, and the world. Those cases illustrate well how Japan's identities actually shaped Japan's behaviors. Last, Japan's responses were considered to be successful, at least in terms of foreign and security policies. What made it possible for such an evaluation must now be explored.

\section{The War on Terror}

On September 11, 2001, the Japanese government swiftly formulated its response after the terrorist attack thanks to the guidance that already existed for emergencies from their previous experiences with the Gulf War and the 1995 Hanshin Earthquake. The Japanese government had expressed its will to respond to any emergencies swiftly and effectively in order to promote a government that is trusted by its people. The Japanese government established the Emergency Anti-Terrorism Headquarters headed by the Prime Minister Koizumi within a few hours after the terrorist attack against the U.S., which showed the Japanese government's understanding of the event as a "significant emergency [Kinkyu Jitai]" (Shinoda, 2001, p. 91). The next day, the Japanese government issued its initial response to this emergency, vowing to increase its efforts to protect Japanese nationals and the facilities related to the U.S., as well as pledging their cooperation with the U.S.

Simultaneously, the Japanese government emphasized an affective understanding of this terrorist attack. On September 12, 2002, Prime Minister Koizumi issued a very strong statement on this matter and defined the acts as "vicious and unforgivable acts of violence" and that "such acts of terrorism are totally unacceptable. I am outraged." He then expressed his empathy to the U.S. as the representative of Japan (Koizumi, 2001b). 
Prime Minister Koizumi declared that the terrorist attack was a challenge against the free world. He also emphasized that not only Americans, but also Japanese were victimized. On September 23, 2001, the Japanese government again delivered the following powerful message:

We must stand up with firm resolve to acts of terrorism, together with other nations of the world. At the same time, I would like to express my deep condolences for all who were killed as a result of these acts of terrorism.

People around the world share sadness and pain, as well as strong anger toward terrorism. I understand that in New York many Japanese are working as volunteers, that some are participating in the rescue activities, that some are in line to donate blood, and furthermore, that many people have made a donation. Here in Japan too, many people have visited the Embassy of the United States to present flowers. Efforts to collect contributions are also underway, through various routes. To express our feelings of condolences for those who selflessly gave their lives to save others and to support the rescue and relief efforts, the Government of Japan has taken a decision to contribute $\$ 10$ million dollars. The Government of Japan is firmly resolved to strive for the eradication of terrorism. At the same time, as an ally, Japan strongly supports the United States and is resolved to do its utmost in offering assistance and cooperation. (Koizumi, 2001c) What these statements invoked was the unity between the U.S. and Japan based on the pain and anger they both shared. Japan's senior partner, the U.S., was in pain. The U.S. had to take action in order to protect itself and recover international order, from which Japan also benefitted. As an ally of the U.S., Japan should then have no problem helping 
the U.S. achieve its goals. Expressing firm support, Japan had to decide how to cooperate with the U.S. The U.S. quickly decided to begin military operations against Afghanistan. NATO and Australia showed their support and cooperation by declaring the right to collective defense as allies of the U.S. In addition to the affective connections evoked, the Japanese government issued a strong statement that Japan would be part of an attempt to "combat" or "eradicate" terrorism. Japan also declared that the combat against terrorism was Japan's own security issue. The security can be achieved by promoting the bond between Japan and the U.S., as well as promoting the ideal Japanese sons, who were respected by the members of international community.

Japan's mobilization of SDFs to the war in Afghanistan was successful overall. Japan could simultaneously project the trustworthy relations between the Japanese government (boss) and sons (SDFs,) as well as between the U.S. (senior partner) and Japan (hardworking junior partner). It is true that dispatching the Maritime Self Defense Force (MSDF) on oil replenishing missions based on the newly adopted Antiterrorism Special Measures Law in 2001 pushed the boundaries of what Japan's SDF were allowed to do under the current Japanese Constitution, which banned Japan from resolving international issues through the use of force. Yet, the overall positive evaluation of these policies depended on how Japan was seen by the U.S. and other international community. As long as Japan was favored by the U.S. and respected by other countries, Japan could feel secure because that is how the world should look.

\section{The Iraq War: Resuming Being Humanitarian Japanese Sons}

Japan made several critical decisions relating to the Iraq War and its aftermath. Japan supported the U.S. war against Iraq. Japan dispatched SDFs to Iraq, but only for 
humanitarian and reconstruction missions. Last, Japan withdrew the Ground SDFs from Iraq in July of 2006 as relations between Japan and the U.S. deviated from what Japan expected.

The U.S. announced its plans to invade Iraq in March of 2003 without UN authorization, unlike the War on Terror. The international community criticized this move by the U.S. The war in Iraq was also overwhelmingly unpopular among the Japanese (Kingston, 2004). Prime Minister Koizumi evoked the image of the U.S. as the struggling senior partner who had to make an unwanted decision:

President Bush emphasized that he warned Iraq that if the Hussein administration does not choose the way of peace, the US is obliged to resort to military action. Japan up to now has aimed at a peaceful solution under international collaboration and exerted its own diplomatic efforts. Having listened to President Bush's speech, I felt that it must have been a painful decision. The President must have made various efforts to obtain international collaboration. Under such circumstance, President Bush was left with no other option, and I support this. (Koizumi, 2003a)

Prime Minister Koizumi firmly stated that Japan would not participate in the war, thus carefully distancing itself from the belligerent U.S. He then stated that Japan would make its own decisions about what to do for the reconstruction of postwar Iraq, emphasizing that Japan was not a mere follower or subordinate of the U.S. Japan also reminded listeners that in case of a crisis against Japan, the U.S. would be the only nation to offer help or rescue. He emphasized that supporting the U.S. was in Japan's own self interest. Read together, Japan would distance itself from the belligerent U.S., however, the 
belligerent U.S. was not an enemy of Japan and should not be completely refused, just like Japan could not completely refuse the Imperial Japanese fathers in the films:

The United States has clearly stated that an attack on Japan would be an attack on the United States. The United States is the only country that clearly states that an attack on Japan would be considered as an attack on the United States. The people of Japan should not forget that the fact that the United States deems the attack to Japan as an attack to itself is serving as a great deterrent against any country attempting to attack on Japan. (Koizumi, 2003b)

Japan's decision to support the U.S. war against Iraq seemed to further push the boundaries of the acceptable use of force just for the sake of cooperating with the U.S. since this war was not supported by the UN or the international community. As Oros (2008) stated, the MSDF's missions in the Indian Ocean also pushed the boundaries of acceptable international behaviors of the SDFs by allowing the MSDF to engage in nonhumanitarian missions. In 2002, Japan legalized the SDF's participation in PKF missions. The U.S. also was hoping that "the SDF would take responsibility for governing a sector of Iraq, including the defensive use of force in necessary" (Samuels, 2007, p. 99).

On July 26, 2003, the "Law Concerning the Special Measures for Humanitarian and Reconstruction Assistance in Iraq" successfully passed the Diet. Yet, the proposed activities of the SDF's rather restored the boundaries for the ideal Japanese sons by assigning a humanitarian nature to the missions. The Japanese government continuously stated that the SDFs would not participate in any combat activities. Again, the Japanese government simultaneously emphasized that Japan's Act would serve to bolster close relations between the U.S. and Japan. The relationship was characterized as the U.S. 
being the self-sacrificing senior that needed help and its trustworthy junior partner Japan. Koizumi stated as follows:

The United States is a unique ally for Japan. Despite the great sacrifices it has made, the United States now continues to strive on in its efforts to create a stable, democratic administration in Iraq. [...]The United States is Japan's ally, and I believe that Japan must also be a trustworthy ally for the United States. It is from that perspective as well that I recognize the extreme importance of maintaining the relations of trust within the Japan-US alliance. [...] At the same time, I do not believe that the United States alone can succeed in providing assistance for the reconstruction of Iraq. (Koizumi, 2003c)

Japan's beloved senior partner was in trouble, and Japan must help them. And as if it should be, the Prime Minister Koizumi added that the SDFs, the Japanese sons, and daughters were enthusiastic about the missions:

I am concerned about how the members of the SDF feel about the current situation. However, I was truly encouraged and filled with pride when the Minister of State for Defense informed me that in response to orders many SDF members are burning with a sense of mission and are firmly resolved to go to Iraq. (Koizumi, 2003c)

Japan managed to send as many as 600 SDF personnel to Iraq. On December 9, 2004, the Japanese government announced they were to extend the activities of the SDFs in Iraq for another year. To justify the extension, the support and request from Iraq was emphasized. On December 8, 2005, another one-year extension was announced: 
This Monday, I had a meeting with Mr. Ibrahim Al Ja'fari Al Eshaiker, the Prime Minister of the Government of Iraq, on the occasion of his visit to Japan. Prime Minister Al Ja'fari stated that he highly valued the activities conducted by the SDF in Iraq. He directly requested the continuation of the activities of the SDF for humanitarian and reconstruction assistance. (Koizumi, 2005b)

Japan's understanding of the U.S. as an ideal senior partner made Japan expect the U.S. to understand Japan's pains as well. Japan again defined the U.S. war on Iraq as a difficult and painful decision that Japan could understand and support. In return, Japan wished for the U.S. to understand the biggest source of Japan's sense of insecurity, North Korean abduction issues. The U.S. delivered by declaring that they would firmly support Japan's positions, and would not lift the U.S. economic sanctions against North Korea unless North Korea cooperated with Japan one the matter of abductions. (McCormack, 2007, p. 65) The interactions with the U.S. were also satisfactory since the U.S. looked to be understanding of Japan's concerns, just like a good and considerate boss should be. ${ }^{9}$

Still, Japan faced various challenges. Japan had acquired a new determination in its commitment to the SDF deployment. Japan's operations in Iraq were derailed neither by the withdrawal of Spanish troops in 2004, nor by the traumatic kidnappings of Japanese citizens, the killing of journalists, or the beheading of a Japanese hostage in Iraq that year. In fact, public opinion remained relatively supportive of the SDF deployment despite these incidents, and none of these incidents eroded the Japanese public support for the SDF's missions in Iraq (Hughes, 2004). Yet, Japan's failed attempts to reform the

\footnotetext{
${ }^{9}$ Acharya (2003) notes that a faction of the Bush administration was not really interested in seeking help in terms of military operations from the allies since they would not be able to catch up with the U.S. power anyway. That perhaps explains the U.S. attitudes toward Japan at that moment. (see The Bush Doctrine and Asian Regional Order, P.245)
} 
UN so that Japan could be a permanent member of the UNSC questioned if the U.S. was reciprocating Japan's willingness to support the U.S.' agendas. As time passed, it also became much clearer that the justification for the Iraq War was questionable. Thus, Japan was unable to maintain the U.S. as an ideal senior partner, rather seeing the U.S. as a selfish and belligerent state. As a result, Japan had to withdraw from Iraq.

Japan had successfully portrayed the images of competent and humble Japanese sons in the international arena through the MSDF's refueling missions in the Indian Ocean, as well as through the SDFs' participation in Iraq's reconstruction. Retrospectively speaking, both missions did little to accomplish their original purposes, which were to help combat and eradicate international terrorism, help Iraq recover from war damage, and help Iraq construct a peaceful and prosperous nation state. Still, these efforts helped bring about closer relations between the Japan and the U.S., and helped Japan gain respect in the international community for their generosity and willingness to help in donating fuel. At the same time, Japan was still able to uphold its values and not join combat missions that displayed brute force.

\section{Japan, Northeast Asia as Neighborhood, and Asian Neighbors}

Japan's interactions with Northeast Asian states also displayed the same preference to keep a distance from authoritarian and belligerent others, but at the same time, Japan desired to see an ideal Northeast Asia that was equivalent to the traditional community in which the ideal and benign neighbors pleasantly cohabitate together. In such an ideal traditional community, however, each country was expected to play different roles in relation to Japan. Japan expected the most from South Korea. Japan desired to discipline North Korea, but did not want to kill or destroy it since North Korea 
was still a part of Northeast Asia, and could still be an ideal neighbor for Japan in the future. With respect to China, Japan really did not know how to approach them.

\section{Japan-South Korea Relations: The Illusion of the Poster Child in the Neighborhood}

Beginning in the late 1990s, South Korea significantly increased its presence in Japan's security and foreign policies. Unlike relations with the U.S., Japan understood itself to still be a leader to other states. South Korea was a new member among liberal, democratic, and economically advanced countries, which situated Japan as their senior, but both were from the same neighborhood and shared fundamental values. Since the late 1990s, Japan has repeatedly named South Korea as one of their most important and closest neighboring countries. Japan's understanding of its relationship with South Korea paralleled the relationship between Japanese men who lost confidence and pride and the woman and/or children who were willing to unconditionally care and support those men.

South Korea's currency crisis was a great opportunity for Japan to display its friendship towards South Korea. South Korea became a subject of an IMF-led economic reform, and Japan provided as much as $\$ 10$ billion out of the $\$ 58$ billion South Korea received from the IMF in financial aid. By providing economic assistance, Japan displayed its role as a friendly senior to South Korea.

In 1998, the newly elected South Korean President Kim Dae-Jung visited Japan. That same year, the Japan-Republic of Korea Joint Declaration was established between the two countries. The New Japan-Republic of Korea (ROK) Partnership Towards a Twenty-First Century (hereafter referred to as the 1998 Japan-ROK Joint Declaration) reflected a polite South Korea who was positively responding to Japan's generous 
financial assistance. The Post-Lost Decade Japan read the 1998 Japan-ROK Joint Declaration as follows:

The two leaders shared the view that in order for Japan and the Republic of Korea to build solid, good-neighborly and friendly relations in the twenty-first century, it was important that both countries squarely face the past and develop relations based on mutual understanding and trust. [...] Looking back on the relations between Japan and the Republic of Korea during this century, Prime Minister Obuchi regarded in a spirit of humility the fact of history that Japan caused, during a certain period in the past, tremendous damage and suffering to the people of the Republic of Korea through its colonial rule, and expressed his deep remorse and heartfelt apology for this fact. President Kim accepted with sincerity this statement of Prime Minister Obuchi's recognition of history and expressed his appreciation for it. He also expressed his view that the present calls upon both countries to overcome their unfortunate history and to build a future-oriented relationship based on reconciliation as well as good-neighborly and friendly cooperation. (Japan-Republic of Korea Joint Declaration, 1998)

The agreement also produced an idealized view of the way Japan-South Korea relations had been since 1965. The past relationship was defined in terms of being the process for culminating a friendship, and now Japan and South Korea were at the stage in which that friendship would be further developed. South Korea even positively evaluated Japan's economic assistances in the past. Japan emphasized that they too faced economic difficulties, but were still willing to assist other countries experiencing the same hardship: 
President Kim appreciated the economic assistance to the Republic of Korea from Japan in the past in a wide range of areas including finance, investment and technological transfer, and explained the efforts of the Republic of Korea to resolve its economic problems. Prime Minister Obuchi explained the various measures for reviving the Japanese economy and the economic assistance which Japan is providing to assist in overcoming the difficulties faced by Asian economies, and expressed Japan's intention to continue support for the efforts being made by the Republic of Korea to overcome its economic difficulties. Both leaders welcomed that a basic agreement was reached on loans from the ExportImport Bank of Japan to the Republic of Korea which properly utilizes the fiscal investment and loan program. (Japan-Republic of Korea Joint Declaration, 1998)

The agreement offers the official story for the relationship between Japan and South Korea. The Prime Minister Obuchi summarized this story based on Japan's desires:

The situation on the Korean Peninsula exerts a great influence on the national security of Japan. As a result of the discussions with President Kim Dae Jung of the Republic of Korea last autumn, our two countries have settled all past issues and moved forward to become true neighbors both geographically and in spirit. (Obuchi, 1999)

\section{Japan-South Korea Security Cooperation and Frictions}

Japan's love towards South Korea is indeed striking compared to its behavior toward North Korea or China. On May 7, 2001, Japan stated that: "Japan shares the values of democracy with its closest geographic neighbor, the Republic of Korea, and the importance of this relationship cannot be overstated" (Koizumi, 2001a). Yet, as the 
cinematic identities disseminate, the Post-Lost Decade Japan bonded with the lesser others when their tremendous generosity was displayed, which could be tested through the lesser others making decisions that favor Japan. In this regard, the historical and territorial disputes between Japan and South Korea became the testing ground for the friendship between Japan and South Korea. As expected, the Japanese government did not refrain from behaviors understood to be major contributing sources of friction between Japan and South Korea, although South Korea communicated that such behaviors did not represent the true friendship between Japan and South Korea (McCormack, 2007, p. 92). Prime Minister Koizumi paid homage to the Yasukuni Shrine every year while in office. The Prime Minister was well aware of the opposition to his visits, but he suggested that doing so any day other than August 15 was acceptable.

Yet, Japan expected cooperation from South Korea, which they received for some period of time. In 2001, South Korea, along with China, requested for the Japanese government to modify a textbook. Japan only agreed to make minimal changes, which did not satisfy South Korea. South Korea in turn suspended its policies to legalize the circulation of Japanese cultural products (Togo, 2010, p. 175) Yet, Japan and South Korea were still able to successfully cohost the soccer World Cup in 2002, reaffirming friendly relations. South Korea also showed understanding towards Japan's attempts to normalize diplomatic relations with North Korea. This was a big step forward from the past when South Korea was very critical on the matter since any economic cooperation between Japan and North Korea as a result of relations becoming normalized could have helped strengthen North Korea's military capabilities. Such cooperation by South Korea did not last long. In 2005, South Korea announced that it would not support Japan's 
attempt to reform the UN so that Japan could be a permanent member of the Security Council along with Germany, Brazil, and India. In 2005, South Korea also sent twenty gunboats to stop Japan's research activities near Takeshima/Docto (Arase, 2007). In 2005, Prime Minister Koizumi still stated that:

I deepened the friendly relations with President Roh Moo Hyon of the Republic of Korea through the reciprocal visits last year. In the Japan-Korea Friendship Year 2005 , which marks the $40^{\text {th }}$ anniversary of the normalization of the relations, we will further expand exchanges in all areas. (Koizumi, 2005a)

Professionals or specialists inside and outside of Japan would easily have predicted such deteriorating reactions from South Korea. Yet, Japan's expectations on South Korea based on Japan's ideal relation between the self and the lesser others who share fundamental values with Japan served to enable Japan to behave otherwise. For the Post-Lost Decade, Japan could be secure when relations between the self and others at home were in order, which can be confirmed by seeing how South Korea, the beloved subordinate, obeyed the superior, Japan. Therefore, during the Post-Lost Decade, Japan kept trying to see if South Korea could become such an other who would help secure Japan.

\section{Japan-North Korea Relations: Dear Delinquent in the Neighborhood}

Japan implemented various measures that would not have been possible without an understanding of North Korea as the delinquent youth in cinematic identities. Japan promoted their own security by projecting the respected self through the docile and lesser other for interactions with South Korea. With North Korea, Japan gained security by projecting the proud self who disciplined and punished the wrong lesser other for 
interacting with North Korea. The Post-Lost Decade Japan, who found North Korea a challenger to the existing law and order, redefined North Korea not only as a challenger to Japan's authority, but also as a criminal whose behaviors must be controlled and/or punished.

It should be noted that such an understanding of North Korea was historically contingent; therefore, it did not exist when the Japanese government officially expressed a will to improve relations with North Korea upon the end of Cold War (Togo, 2010). Japan expressed remorse for its wrongdoing and proposed economic cooperation in order to compensate for the damage and suffering Japan caused during colonial rule. Like Japan's interactions with South Korea, Japan first presented itself as a former victimizer and then a potential good neighbor to North Korea who wanted to help with economic development. Japan and North Korea had negotiated over the terms, but could not reach an agreement throughout the 1990s.

The Japanese government presented itself as humble, sincere, and sensible to the past history of Imperial Japan, who had caused tremendous suffering to people around Asia. The Japanese government stated that Japan was interested in improving relations with North Korea and would be pleased to cooperate with North Korea if that country wished for the same. The government also stated Japan should keep in its place since they were the former colonizer or oppressor. A formal negotiation was started in January of 1991, but ended in November of 1992 without producing any agreement. According to the Japanese government, North Korea claimed that it had nothing to do with a missing Japanese person believed to be in North Korea, and Japan refused to continue the negotiations (MOFA, 1993). The Japanese government was aware of other kidnapping 
issues and alleged spy activity by North Korea, however, Japan at that time still desired to seek normalization of relations with North Korea.

\section{Criminalizing North Korea through the Normalization Negotiations}

By the end of the 1990s, North Korea was widely identified with the nuclear issue, the development of middle to long-range missiles, and the past abductions of Japanese people. One of the kidnapping victims, Megumi Yokota, was as young as thirteen years old, which outraged Japanese society. The Association of the Families of Victims Kidnapped by North Korea in 1997 and the National Association for the Rescue of Japanese Kidnapped in 1998 were established respectively and lobbied heavily for the government of Japan to take action to resolve the abduction issue. All North Korean misbehaviors were understood as acts of refusal to observe the existing rules among nation states.

In August of 1998, North Korea communicated its will to resume normalization talks with Japan, to which Japan agreed. Nevertheless, Japan decided to freeze its commitments to the projects by the Korean Peninsula Energy Development Organization (KEDO) after a North Korean missile incident on August 31, 1998. Yet, changes in the international environment surrounding North Korea again motivated Japan to resume the normalization talks. The hostility between South Korea and North Korea was eased when South Korea announced a softer approach named "The Sunshine Policy" towards North Korea. North Korea also started successfully normalizing relations with European countries at this time. In the Japanese Diet, it was suggested that Japan should not be late to arrive to this international trend. 
On October 21, 1998, Japan announced they would resume the KEDO project, arguing that stopping the KEDO project would encourage North Korea to further develop nuclear weapons. In March of 1999, Japan found a North Korean spy vessel in its territorial waters, and did not resume normalization talks until December of that year. In October of 2000, Japan sent 500,000 tons of rice to North Korea as a gesture of goodwill. Yet, in December of 2001, Japan found another unidentified vessel later confirmed to be a North Korean spy ship.

After not holding a meeting for close to two years, the Japanese government announced plans to visit North Korea. In September of 2002, Prime Minister Koizumi and General Secretary Kim Jong Il held talks in Pyongyang, the capital of North Korea. The purpose of the normalization talk was simply stated to be the "historical responsibility of the Government." Prime Minister Koizumi also stated that he strongly felt the need for a better understanding of North Korea through a direct exchange of words. Resolving the issue of the seventeen Japanese citizens kidnapped by North Korea during the 1970s and 1980s became one of the most important foreign policy agendas for Japan in the 2000s. The Japanese government emphasized the gravity of the matter, stating that the abductions affected the "sovereignty of Japan" as well as "the lives and safety of the Japanese people.” The government of Japan also articulated that maintaining the safety and prosperity of Japan and its people was the most important task for Japan's security policies.

The meeting was successful overall and the "Japan-DPRK Pyongyang Declaration" was announced. North Korea's Chairman Kim Jong-Il admitted that someone related to North Korea abducted the Japanese and apologized for the events. As 
soon as North Korea admitted the abductions, North Korea was labeled a criminal state, situating Japan in the position of the discipliner of North Korea. Japanese politicians stated that Japan must normalize North Korea. Naming North Korea as a criminal further justified the idea that Japan would not normalize diplomatic relations with such a state, although Japan did have diplomatic relations other nation states that had human rights violations, just not neighboring states with specific crimes against Japanese citizens like North Korea. Japan's policy toward North Korea was now to stop diplomatic relations for normalizing North Korea until the abduction issue was fully resolved. Japan would now also seek to resolve the abduction issue and the nuclear and missile issues simultaneously. Japan was to pressure North Korea through any foreign policy tools, including diplomacy and economic sanctions.

Ministry of Foreign Affairs of Japan (MOFA) had long interpreted North Korea's provocative behaviors as intended to bring the U.S. and Japan back to the negotiation table in order to get economic support and have the regime continue to survive (Fouse, 2004). North Korea also communicated to Japan that any attempts to develop nuclear weapons and middle to long-range missiles were responses to the U.S.' hostile policies toward North Korea. North Korea desired to resolve these issues through dialogue with the U.S., therefore, North Korea remained in line with the 2003 declarations. Yet, the Japanese government continued to suggest that the meaning of North Korea's words and actions were not intelligible to Japan, thus implying that North Korea could not be trusted. Japan also said that North Korea might have been trying to obtain nuclear capabilities and was using the nuclear issue as a bargaining chip for trying to obtain other gains. North Korea was documented in Japan's official political discourse for the "extremely closed 
nature of the country;" therefore, Japan could not know the details of North Korea's missile developments (Japan Defense Agency ${ }^{10}, 2005$, p. 9).

Japan continued to try to define North Korea as a delinquent and criminal state, despite various friendly gestures from North Korea. In May of 2004, Prime Minister Koizumi visited North Korea, who again entertained Japan's requests. Chairman Kim Jong-Il agreed to allow the five family members to unite with the abductees who had previously returned and remained in Japan since 2002 against the initial agreement between Japan and North Korea. He also agreed to continue the investigations into the whereabouts of the rest of the alleged abductees. North Korea also agreed to confirm the 2002 Pyongyang Declaration. North Korea also expressed a will to resolve the nuclear and missile issues through the Six-Party Talks. The Chairman also affirmed a continuation for the moratorium of missile tests. In return, Japan promised to provide food and pharmaceutical supplies to North Korea.

In December of 2004, North Korea sent the purported remains of Megumi to Japan to prove that she was deceased. As soon as the DNA test proved that the remains did not belong to Megumi, Japan concluded that North Korea must also have been dishonest about the eight people whom North Korea previously said were deceased (McCormack, 2007). Japan then cancelled the shipment of rice and goods promised to North Korea, as if to say North Korea did not even deserve humanitarian aid.

In July of 2006, North Korea again conducted missile tests. Japan made sure that North Korea was seen as the delinquent who challenged the existing order by sponsoring the UN resolution. To Japan's satisfaction, the UNSC Resolution 1695 adopted on July

\footnotetext{
${ }^{10}$ Japan Defense Agency was upgraded to the Ministry of Defense in 2007.
} 
15, 2006, condemned North Korea's launch of ballistic missiles as an act threatening regional peace and stability, and reminded North Korea that they were in breach of international agreements. Japan also announced its own economic sanction measures, and some Japanese politicians even suggested a military strike against North Korea in retaliation (Park \& Vogel, 2007). On October 9, 2006, North Korea for the first time conducted a nuclear test. The U.S. finally delisted North Korea from the terrorismsponsoring list in 2007. Yet, Japan did not change its policies even if it thought it could have led to Japan's international isolation. Further, Japan was unable to solve their security issues anymore through interaction with North Korea.

Irrespective of many voices criticizing it, Japan would not make any compromises in its policies against North Korea. This situation with North Korea was actually a blessing in disguise for Japan in that Japan used the matter to recover their sense of rightness. At the same time, it is also evident that Japan successfully defended itself from being exposed to past wrongdoings while negotiating with North Korea. Japan even made it possible to construct itself as a proud and morally rightful self instead of the remorseful and sorry self of the former colonial rulers and victimizers.

\section{Japan-China Relations}

Japan took a very low-key approach to relations with China, which suggests that although Japan continuously stated that China was one of the most important neighboring countries, China was not helpful to Japan's purpose of securing identity. For the PostLost Decade Japan, the order can be affirmed by projecting interactions with the U.S. as being with a good, like-minded senior partner, with South Korea as a good, docile child, 
and with North Korea as a bad delinquent turned criminal. China does not seem to fit in the imagined filmic world for Japan.

In the real world, Japan's relations with China were referred to as "Cold Politics, Hot Economy." Japan and China's economic interdependence rapidly deepened. Still, China refused to have official bilateral meetings with Japan because of the annual Yasukuni Shrine visits by Japanese Prime Minister Koizumi.

The Post-Lost Decade Japan's understanding of China is fundamentally contested. Japan as a leader in Northeast Asia situated China in a subordinate position. Yet, China was a permanent member of UNSC, and had a huge population and territory much like the U.S. China was a neighboring country, but unlike South Korea, Japan did not share fundamental values with China. China may have behaved in a questionable manner, but they were not nearly as bad as North Korea in the eyes of Japan. Japan was able to interact with China, but in highly fragmented ways that made relations unstable. It seems that Japan somehow saw paralleled in China its own past experience as being a nation undergoing rapid economic development. Japan desired to project its superiority by offering to help China with environmental issues. Japan also refused to do anything about China's internal hate problems, merely calling for cooperation on the Senkaku/Diaoyu issues. It is still unclear where Japan's understanding comes from regarding China except the sheer sense of Japan's sense of superiority.

\section{Japan, the Self, Others, and the World in the 2000s}

In this chapter, Japan's security and foreign policies were explained based on Japan's identities in its Japan's bilateral relations with the U.S., South Korea, and North Korea. It has been demonstrated how Japan's ideal images of the self, the other, and the 
world were imagined in the popular films, and were actualized or tried to be actualized in Japan's reality. It must be noted though that the case of China could not successfully be explained based on the identities and unconscious ideologies.

Japan's ideal identities helped Japan to understand the events and subsequent behaviors they should take. Japan swiftly and effectively responded to the requests from the U.S. after the 9/11 terrorist attacks by sending its SDFs overseas, which Japan could never have done in the past. Prime Minister Koizumi successfully projected the ideal relations between Japan and the U.S. as the good superior and the good subordinate. But at the same time, such ideal relations also generated Japanese expectations for the U.S. to be sympathetic to Japan's own foreign policy agendas.

Japan also enjoyed historically unprecedented amicable relations with South Korea, in which Japan thought South Korea finally came to their senses. Japan understood such gestures on South Korea's part almost for granted because South Korea was the one who should step up for the temporarily unconfident Japan. Japan further expected South Korea to respect Japan's relations with its past on its own terms, thus leaving out the troubling behaviors so that Japan did not have to feel bad about themselves. As to its relations with North Korea, Prime Minister Koizumi successfully realized the joint declaration with North Korea, which was indeed historically unprecedented. Yet, instead of flexibly negotiating with North Korea in order to materialize what were agreed upon in the Pyongyang Declaration, the Japanese government aggressively pushed its own agenda. Eventually, Japan-DPRK relations stalled and Japan could not accomplish any of the goals stated in the Pyongyang Declaration. 
In the 2000s, Japan made new and significant developments in its relations with the U.S., South Korea, and North Korea. The Japanese people overall welcomed the SDFs' positive contributions to the international attempts to eradicate terrorism and to reconstruct postwar Iraq. The increased interactions between Japan and South Korea also left positive notes on the people between the two countries. For the first time since 1945, a summit meeting between Japan and North Korea was realized. Some of the Japanese who were abducted by North Korea also were able to come home.

Yet, Japan's identity as the temporarily unconfident and the normalcy of how such a Japan interacts with the U.S. as the superior, and South and North Korea as the lesser others who should step up for Japan, were functioning as unconscious ideologies. Japan ended up supporting the U.S. Iraq War. Japan was not a wise friend who could influence and advise a U.S. outraged by $9 / 11$ terrorist attacks to not exacerbate the situation. The friendship Japan cemented ended up making Japan simply one of the enablers of the U.S. Japan also could not stop visiting the Yasukuni Shrine. Japan's treatment of North Korea was also regrettable in the sense that Japan abandoned humanitarian aid. Japan became a country that lacked basic compassion for the North Korean people out of a desire to look tough. With South Korea, Japan's sense of superiority made it a disrespectful and unfortunate figure. Still, in the eyes of the Japan Self, these ramifications were small prices to pay, and overall, Japan successfully secured the self at least for that moment. 


\section{CHAPTER 6:}

\section{CONCLUSION}

\section{Introduction}

How have Japan's imagined ideal relations among the self, others, and the world found in Japan's selected popular films corresponded to Japan's foreign and security behaviors in the 1950s and in the 2000s? This dissertation demonstrated that the narratives of the Japanese family from the patriarch's point of view have constantly shaped Japan's foreign and security policies so that the world looks properly hierarchically ordered in the eyes of Japan Self, which in turn enabled Japan to realize a sense of security.

In Japanese films from the late 1940s to the 1950s, the Japanese patriarch reinvented himself as the liberal democratic and peaceful father who cares about his daughters and sons, who in return are expected to willingly submit themselves to the father in the "reel world." Japan constructed asymmetrical security relations with the U.S., expecting the U.S. to help Japan restore the hierarchical orders at home and abroad in the real world. When the behaviors of the U.S. did not constitute what was expected of the behaviors of the good Japanese patriarch, Japan tenaciously and continuously tried to alter the meanings of the U.S. behaviors. In popular films from the late 1990s to the mid2000s, the still liberal, democratic, and peaceful Japanese patriarch suffered from a temporarily lost sense of confidence and pride. The rest of the family members such as the sons and daughters were expected to demonstrate their subjugation so that the legitimacy of the father would be recovered. Japan this time proactively contributed to the U.S. responses to the $9 / 11$ terrorist attacks, but ended up being disappointed whenever 
the U.S. did not demonstrate that it cared for Japan's agendas. Japan also expected South Korea and North Korea to be accommodative to Japan's agendas, which caused Japan's relationships with both to deteriorate.

This conclusion reevaluates the findings of this dissertation. Then, this chapter addresses the implications for: 1) the scholarship of IR; and 2) Japanese and U.S. policy makers. Finally, the conclusion discusses the future of studies of the identity, ideology, and foreign and security policies of Japan. Understanding Japan's foreign and security policies through Japan's imagined ideal social orders helps to further explore the ways for Japan to construct better relations with the U.S. and its Asian neighbors by engaging in self-reflection.

\section{From the "Reel World" to the Real World: Refining the Process and the Dynamics}

This dissertation has demonstrated that the identities and unconscious ideologies found in popular cultural products, mostly films, but also literature have helped Japan to understand what or who it observed, and then how to interact with the other states in the way it should in the real world. These films did not provide any specific behavioral guidance or exact rules for Japan to follow. Yet, Japan's foreign and security policies can be well understood based on how the world should naturally look from the perspectives of the Japanese patriarch.

From the late 1940 s to the mid-1950s, many films were produced and screened in Japan. These popular films showed what it meant to be a defeated Japan, an occupied Japan, an independent Japan, and a liberal, democratic, and peaceful Japan when read together. The defeated and occupied Japan was mostly associated with the sense of humiliation that could not continue to be a part of Japan's reality. What it meant to be an 
independent Japan was not an easy question, but the films suggested that not being a defeated and occupied nation could mean an independent Japan. The liberal, democratic, and peaceful Japan meant that Japan would refrain from resorting to coercive measures in resolving any international disputes.

These films also showed what the ideal relations between the patriarch and the rest of the family members should look like. A good Japanese daughter listens to her father, and a bad Japanese daughter gives priority to what she thinks is best for her. But in the end, the Japanese patriarch knows what to do in order to achieve what is best, that is, the unity and continuity of the family. The hierarchical relations between the father and the daughter are always part of a peaceful and even beautiful Japan. The same goes for Japanese sons. Japanese sons should not bond with someone who is not a liberal, democratic, and peaceful father, such as the violent father. The films also show that the peace could be disrupted, but could also be restored if Japanese sons behaved rightly. Facing various threats, be it brutal bandits or Godzilla, Japanese sons may have had to take up weapons for the purpose of self-defense, but such acts do not belong to the everyday peaceful life of the Japanese people.

From the late 1990s to the mid-2000s, Japanese films became popular again for the first time since the 1950s. These popular films show this time how Japan, which temporarily lost its confidence and pride but naturally was full of potential, could not allow this loss to continue to be a part of Japan's reality. The films also showed how Japan could recover from such an identity, or at least could be healed.

These films show how various possible ranges of dangers, from terrorist attacks to environmental disasters, made Japan in the Post-Lost Decade so unusually vulnerable. 
The films also showed that recovering peace is possible again, however, only if Japanese sons do the right things. These ideal Japanese sons are humble but competent. They are young middle class men who devote themselves to saving Japan by doing their jobs, simultaneously affirming and even restoring any lost competence of their senior partners. These films also remind that Japanese sons failed to save Japan by not being able to cut bonds with dangerous Japanese fathers during war in the past. These films also showed not only that Japanese sons, but also daughters, children, and foreigners can have roles to play in the recovery of Japan's identity. The daughters, youth, children, and foreigners have to affirm their identity as the willing subordinates of the Japanese patriarch so that he can recover his sense of pride and confidence.

These representations, meanings, and stories in the "reel world" shaped the subjectivity of Japan as a patriarch in the 1950s and 2000s. These senses of Japan Self have prepared Japan to make sense of the self, the others, and the world in the real world. In the 1950s and then later in the 2000s Japan had various practical policy goals to be achieved and concerns to be addressed. Yet, this dissertation has demonstrated that what Japan continuously did was to engage in battles and struggles over the representations and meanings of the self through foreign and security policies in interacting with various others. Also these self-perceptions of Japanese identity did not always guide Japan to behave in accordance with its interests or moral codes.

The significant accomplishment by these unconscious ideologies, later considered to be an epic mistake, was Japan's asymmetrical security arrangement with the U.S. After agreeing on the 1952 Security Treaty between Japan and the U.S., Japan persistently interacted with the U.S. so that: 1) the U.S. would be obligated to defend Japan while 
Japan was only obligated to defend itself; 2) Japan was fully in charge of domestic disturbances; and 3) Japan did not have to send members of the SDF, the Japanese sons, to foreign wars. The ideal image of the caring and good father and the good daughters and sons made the asymmetrical power relations between the U.S. and Japan normal, but also generated the expectation for the U.S. to care about the well-being of the nation of Japan. The actual U.S. treatment of the Japanese, however, did not meet this expectation and made the U.S. look like a dangerous and violent father, making it impossible for Japan to facilitate military connections between the two. These findings are made possible by the concept of unconscious ideologies.

Similarly, Japan's support of the U.S. Iraq War in 2003, and the dispatch of the SDFs for postwar Iraq reconstruction missions were novel accomplishments that Japan had been unable to do for a long time. Yet these decisions were later questioned as the U.S.' justification for the invasion of Iraq turned out to be untrue. Related to the problem of Iraq, the absence of victorious and successful results for U.S. military operations in response to $9 / 11$ simply confirmed that male bonding through violence was not desirable. In addition, the diminishing support from the U.S. for Japan's agendas contradicted the preferred image of the U.S. as the good superior of Japan. Without Japan's expectations of the U.S. to be a good, caring superior, Japan's disappointment that contributed to the eventual cooling off of relations between the U.S. and Japan still cannot be fully explained. These disappointed expectations are reflected in the popular Japanese films of the 2000s.

This dissertation has also observed that Japan's understanding of the U.S. as the fatherly figure to the nation of Japan corresponds to an interesting dynamic between 
Japan and the U.S. This finding is not explicit from the concept of unconscious ideologies, although it is not impossible to be explained as such. Japan's understanding of the U.S. as its fatherly figure also shaped the ways Japan interacted with other neighboring states. In the 1950s, Japan interacted with the USSR and the PRC only in ways that were permissible in the eyes of the U.S. With respect to relations with the Asian states that suffered from substantial damages as a result of Japan's past invasions, Japan persistently negotiated with them to make reparations and ensure economic cooperation, which in turn contributed to Japan's own economic recovery. It also made it almost impossible to comprehend the behaviors of states such as South Korea, which did not accommodate such demands of Japan. In addition, the image of the U.S. as the fatherly figure for the nation of Japan obscured Japan's own domestic relations. As a result, Japan had to ensure the bonding between Japan as the patriarch and the nation of Japan as the rest of the family by showing Japan's practical and affective ability to care for its people. The results were: 1) drastic reductions and relocations of the U.S. base from the mainland to Okinawa; and 2) Japan's obsessive attempts to pardon and repatriate Japanese war criminals.

These two successful policies during the 1950 s were later found to be very problematic. In the 2000s, Japan similarly expected South Korea and North Korea to be accommodative to Japan's agendas. This time, Japan's ideal image of itself already expected the neighboring others to demonstrate their willing subjugation to Japan. Yet, Japan's understanding of itself as the close junior partner of the U.S. further justified such preferred relations. As a result, Japan strongly pushed its agendas, and caused a 
deterioration in relations with South Korea. Less surprisingly, Japan also was unable to resolve any issues with North Korea.

Overall, this dissertation has successfully demonstrated how identities and unconscious ideologies have shaped Japan's foreign and security policies. This dissertation also found that on many occasions, these unconscious ideologies were indeed very powerful to the extent that Japan tried to match the real world with "reel world," as if there were no other options. Based on these findings, the implications are further discussed in the next sections.

\section{Implications for IR Scholarship}

This dissertation has endeavored to explain Japan's foreign and security policies relying on the notion of identities and unconscious ideologies. This approach contributes to diversification of the existing theoretical and analytical approaches to the study of Japan's foreign and security policies. This dissertation is interpretative, and therefore it does not aim to claim theoretical and methodological superiority to other theoreticallyinduced approaches, such as realism or liberalism-oriented research paradigms. This dissertation also does not claim that my findings are the truth, whereas the others are all wrong. Rather, it argues that we cannot fully understand Japan's foreign and security policies without understanding the country's changing sense of identity. These identities have been both forged and reflected in the popular movies of ensuing post-World War II eras. Accordingly, this dissertation has several implications for scholarship in IR.

This dissertation has demonstrated that understanding Japan's foreign and security policies is possible without relying on the foundational assumption in theoretical approaches to International Relations that the state is the dominant factor, an assumption 
that the neorealists and neoliberals have uncritically employed. These dominant theoretical approaches conceptualize the state as a rational actor, seeking to maximize its probability of survival by increasing its material capabilities under anarchy, which is defined as an absence of central authority that governs states. Alternatively, this dissertation has showed that Japan's foreign and security policies can be understood assuming Japan to be an imagined entity whose idea of the secured self has continuously sought to be realized through its foreign and security policies. These findings support the existing critical security analysis that understands foreign and security policies as discursive acts of securing the sense of self, as Campbell (1992) has argued.

Related to the previous point, this dissertation also contributes to the advancement of the different conceptualizations of the state as an actor or agent. Based on the notion of identity and ideology, this dissertation conceptualizes the state as an acting entity which is capable of acting toward the self, the others, and the world. This understanding of the state then further asks how this acting entity knows how or how not to act towards the world. To answer this question, this dissertation has demonstrated that how a state behaves depends on its worldviews, and this dissertation has emphasized the powerfulness of Japan's imagined ideal orders that functioned as unconscious ideologies that were also historically contingent. These "thicker" accounts of the state challenge the conventional conceptualization of the state as simply rational, and acting in interests that can be defined without reference to identity.

The findings of this dissertation also have implications for the ongoing debate on how to understand changes in the foreign and security policies of Japan. The scholars who emphasized the culture of anti-militarism have sought to understand how the change 
could occur. For example, Oros (2008) argued that the changes in Japan's security environment, the dissolution of the U.S.-Japan security alliance, and the consensus to change Japan's current security and foreign policies among Japan's political parties may alter Japan's pacifist policies. Alternatively, this dissertation suggests that Japan's pacifist policies may change when Japan's unconscious ideologies have changed. As this dissertation has shown, though implicitly, Japanese popular films have conveyed the narratives in which the bonding between the violent father and the sons results in wars that bring misery in the 1950s. This understanding of violence and war functions as unconscious ideology, and makes Japan Self constantly expect the reality to be in line with this narrative. A similar narrative was found in the popular films in the 2000 s, which suggests that these cultural products can help us understand the continued aspect of Japan's pacifist policies even though majority of the Japanese in the 2000s did not experience the misery of the war and violence in the past. Then, for example, if Japan's foreign and security policies dramatically changed enough so that Japan could send the members of SDFs to foreign wars, this narrative of violence and war must be changed.

What then has to be further explored will indeed be how the narratives of violence and war change. Should a government that desired to change Japan's pacifist security policies, for example, sponsor a film or write literature that celebrates violence and war? To answer such a question will not be straightforward, but at least this study points to the cultural products that are to be a part of change.

This dissertation also adds support to the call for the return of culture to IR. As Chapter Three has demonstrated, this dissertation has explained Japan's security relations to the U.S. during the 1950s as the product of Japan's unconscious ideologies. Japan, not 
being a great world power, naturally sought to bond with the stronger U.S. Yet, the means through which Japan bonded with the U.S. were strongly shaped by Japan's understanding of the ideal relations between the good patriarch and the rest of his family members. This expectation for the U.S. to be a good fatherly figure to the nation of Japan was well satisfied whenever the U.S. helped Japan increase its social standing in the international community. At the same time, this expectation made Japan and the nation of Japan shocked and outraged whenever the U.S.' behaviors did not match what was expected of a caring and considerate father. These detailed understanding of Japan-the U.S. relations was possible by analyzing the films and the literatures in the 1950s.

This cultural line of analysis also achieves a value-neutral understanding of Japan that is very different from other theoretical and analytical approaches to Japan's foreign and security policies. It does not assume Japan to be benign or good. Other approaches produce knowledge that "others" Japan or unreasonably discredit its behaviors. For example, as mentioned in Chapter One, neorealism explains Japan's foreign and security policies in the 1950s as "a realist strategy of buck-passing" (Lind, 2004, p.93). In the view of neorealists, during the Cold War rivalry between the U.S. and the USSR, Japan simply took advantage of a U.S., which was able and willing to defend Japan from external threat. Under the U.S. security umbrella, Japan could achieve economic growth while keeping its defense spending minimal. This line of analysis understands Japan as an opportunistic actor. Similarly, Berger (2007) states: “Japan’s minimalist stance on foreign affairs was a perfectly logical form of free riding” (p.265). Studies of Japan's foreign and security policies should distance themselves from producing the knowledge that can be easily used for the act of "othering" of Japan or unreasonably discrediting its behaviors. 


\section{Implications for Japan's Policymakers}

This dissertation has demonstrated how Japan's foreign and security policies were shaped by unconscious ideologies. As this dissertation has also demonstrated, Japan has made various foreign and security policy decisions subject to criticism from both inside and outside the country. For example, the U.S. often criticizes Japan's policies that heavily depend on the U.S. security guarantees as a cunning strategy through which Japan can keep its military budgets lower. On the other hand, the same policies are described as a smart strategy that enabled Japan to achieve a miraculous economic recovery after the defeat. Similarly, some Japanese criticized Japan's decision to fully support the invasion of Iraq because of it being illegal. On the other hand, because of the resultant dramatic improvement of Japan's relations with the U.S., some still evaluate that decision positively.

Introducing unconscious ideologies themselves does not automatically allow Japanese policy makers to judge any resultant foreign and security policies. Still, it would be plausible for Japanese policy makers to remember that what Japan legitimately did or did not to do in the past may no longer be justifiable at a the later time. Many decisions could look wrong as time passes, and then, that would be a good time to reevaluate its past behaviors.

At the same time, the notion of unconscious ideology as Japan's powerful belief structure helps the Japanese policy makers to critically evaluate Japan's foreign and security policies. Do Japan's foreign policies facilitate or challenge the existing uneven distribution of power and other resources? Japan's unconscious ideologies that saw the hierarchical relations between the patriarch and the rest of the family natural and normal, 
for example, support the maintenance of the current power structure, instead of challenging it.

Related to this point, the author suggests that Japanese policy makers should take seriously the effect of such unconscious ideology on Japan's relations with its Asian neighbors. As this dissertation demonstrated in Chapter 3 and Chapter 5, Japan's difficult relations with its Asian neighbors can be understood partly as the results of Japan's sense of superiority over them, which had limited Japan's possible policy options but also inevitably made the interactions difficult since such belief clearly contradicts the notion of sovereign equality to begin with. If Japan emancipates itself from the powerful belief in the normalcy of hierarchical relations, Japan indeed will have more flexibility in resolving any practical issues Japan faces or will face. Again, this dissertation cannot answer how unconscious ideologies can be changed. But as this dissertation implicitly suggests, cultural products are indeed one of the powerful sites where commonsensical worldviews are imagined and disseminated. If the unconscious ideologies are what we imagined, there should be the way to re-imagine them in different ways. ${ }^{11}$ By doing so, it might also be possible to realize different foreign and security policies.

The concept of unconscious ideologies also invites Japan to recognize the possibility of the clash between different worldviews when confrontations have been observed. As much as Japan believes itself to be righteous, the other parties believe so as

\footnotetext{
${ }^{11}$ Patton (2007), for example, suggests an interesting link between the films, critiques of the films, and social changes. She suggests that the film like Pinky (1949) may have shaped certain ways some of the American audiences understood the validity of the anti-racism civil rights movements. It surely should be noted that the majority of authors including Patton do not claim any straightforward relations between films and social realities. If not the film, new researches on the social imaginary might be also helpful to further explore possibility of changes. "Modern Social Imaginaries" (2003) by Charles Taylor is one of the influential works that have inspired such research.
} 
well. That being the case, better negotiation is possible when Japan has paid attention to what kinds of narratives the other negotiating party has in mind. By being aware of its diplomatic partners' unconscious ideologies, better cooperation may be possible. In doing so, Japan may also be able to understand the needs of the countries it was puzzled about in the past. Moreover, in trying to understand China, South Korea, or North Korea from the perspectives of their identities and worldviews, Japan might be able to find a way to integrate each narrative together to make a sharable one. Understanding its neighbors based on their identity and unconscious ideology may contribute to producing policies that could facilitate cooperation, or at least avoid fueling unnecessarily enmity.

\section{Implications for U.S. Policymakers}

The findings of this dissertation also acknowledge that the U.S. has been playing an important role in the reproduction of Japan's foreign and security policies that are not in line with U.S. demands, despite the fact that Japan has substantially depended on the U.S. for its security. ${ }^{12}$ Some of the Realists, like Mearsheimer (2001), may still want to believe that material capabilities matter the most. Thus, Japan should have simply obeyed the U.S. Indeed, since as early as the late 1940s, the U.S. has wanted Japan to become a country with a military sufficient to realize its rights to belligerency, collective security, and collective self-defense. The findings of this study, however, indicate that it is most likely infeasible to make Japan a country that could participate in U.S. foreign wars if the findings in the $1950 \mathrm{~s}$ and $2000 \mathrm{~s}$ are still applicable. It is because Japan's military cooperation is possible when Japan has recognized the U.S. as its benign superior. In

\footnotetext{
${ }^{12}$ Some studies also suggest that the U.S.' understanding of Japan at that time also can be seen in some cultural products, which could explain how the enmity between the U.S.-Japan could be tamed after the World War II. (See Shibusawa (2010) for example.)
} 
Japan's imagination, bonding with the U.S. through violence is dangerous. Therefore, what is needed will be a clear separation of the duties and obligations between the U.S. military and Japanese military. Instead of trying to integrate Japan under the U.S. military chain of command, the U.S. could make the space for Japan to positively bond with the nation of Japan. As long as the U.S. resists the urge to fully control Japan, and let Japan contribute to the U.S. interests in the way it desires, it will most likely get the best support possible from Japan.

\section{Future Research on Identity, Ideology, and Japan's Foreign and Security Policies}

Campbell (1992) wrote in the preface of his seminal book "Writing Security" that "uncertain times demand an unconventional analysis" (p. ix). I strongly believe that this dissertation has been a part of much needed effort to develop new and different types of analysis, but also acknowledges that many unanswered questions about the sources of security policies remain. This final section addresses some of the questions this dissertation has raised, hoping that some answers might be found by future studies.

One of the major questions stems from the scope of this study. The subject of this study is limited to Japan's foreign and security policies during the 1950 s and 2000 s. Although there were some similarities found in the 1950s and 2000s, whether or not the unconscious ideologies found in this study can effectively account for Japan's foreign and security policies at different times remains unknown. For the same reason, any generalization based on this study is not warranted. Moreover, familial identities were important in analyzing Japan's films. But other identities such as race or class might be 
usefully applied to other countries. ${ }^{13}$ Thus it will be left to future studies to show if this approach can be usefully applied to the study of foreign and security policies of states other than Japan.

Other problems are largely methodological. This dissertation has mainly used films as the subjects of inquiry, but many different kinds of cultural products such as TV dramas, comic books, paintings, and music may create and/or disseminate unconscious ideologies. Would the use of different cultural products have brought different results? Are there any differences in visual cultural products such as films or TV dramas and written cultural products? Can any specific guidance be used for the selection of the kinds of cultural products? Another question is also related to the selection of the specific films examined. This dissertation deliberately chose to analyze domestically and internationally critically acclaimed films of the 1950s, and domestically widely consumed films of the 2000s. Yet, there are Japanese films produced by Japanese directors who were domestically and/or internationally critically acclaimed at different times. The films by Itami Juzō or Kitano Takeshi in the 1980s and the 1990s can be listed as the examples of such. ${ }^{14}$ Would it be possible to use the films of all periods as the sites where Japan's identities and unconscious ideologies could be found? This dissertation cannot answer these questions, but further exploration is recommended.

\footnotetext{
${ }^{13}$ I am grateful for this suggestion by Dr. Clark.

${ }^{14}$ I am grateful for this suggestion by Dr. Heine. Osōsiki [Funeral] (1984) directed by Itami Juzō, for example, received several of prestigious domestic film awards in Japan. Hana-bi [Fireworks] (1993) directed by Takeshi Kitano won the golden line award, one of the most prestigious international film awards, at the Venice Film Festival. Both Itami and Kitano produced several more of films that were well received by critics. These films may be worthy sites to investigate Japan's identities and unconscious ideologies. It also may be possible to reexamine Japan's foreign and security policies before 1945 based on films. High (2003) for example showed many of the Japanese films were produced and consumed under the authority of Imperial Japan.
} 
Japan is facing various uncertainties in its relations with the U.S., China, South and North Korea, while the Japanese film industry has continued to produce various films that are also widely consumed by the Japanese people. If Japan desires to become more aware of the unconscious ideologies that influence its security policies, it is time to pay more attention to the cultural products of Japan, as well as to that of the neighboring countries, because as this dissertation suggests, what is imagined matters more than is usually thought. 


\section{REFERENCES}

Acharya, A. (2003). The Bush doctrine and Asian regional order: The perils and pitfalls of preemption. Asian Perspective, 27(4), 217-247.

Adams, I. (2001). Political ideology today. New York, NY: Manchester University Press.

Anderson, J. L., \& Richie, D. (1959). The Japanese film: Art and industry. Tokyo: C. E. Tuttle Co.

Arase, D. (2007). Japan the active state? Japan's security policy in the post-9/11 era. Asian Survey, 49(1), 560-583.

Allsop, S. (2003). Battle royale: Challenging global stereotypes within the constructs of a contemporary Japanese slasher film. The Film Journal, 7. Retrieved from http://www.thefilmjournal.com/issue7/battleroyale.html

Barrett, G. (1989). Archetypes in Japanese film: The sociopolitical and religious significance of the principal heroes and heroines. Selinsgrove, PA: Susquehanna University Press.

Berger, T. U. (1993). From sword to chrysanthemum: Japan's culture of anti-militarism. International Security, 17(4), 119-150.

Berger, T. U. (1996). Changing norms of defense and security in Japan and Germany. In P. J. Katzenstein (Ed.), The culture of national security: Norms and identity in world politics (pp. 317-356). New York, NY: Columbia University Press.

Berger, T. U. (1998). Cultures of antimilitarism: National security in Germany and Japan. Baltimore, MD: Johns Hopkins University Press.

Berger, T. U. (2007). The pragmatic liberalism of an adaptive state. In T. U. Berger, M. M. Mochizuki, \& J. Jitsukawa (Eds.), Japan in international politics: The foreign policies of an adaptive state (pp. 259-291). Boulder, CO: Lynne Rienner Publishers.

Buzan, B., \& Wæver, O. (2003). Regions and powers: The structure of international security. Cambridge: Cambridge University Press.

Campbell, D. (1992). Writing security: United States foreign policy and the politics of identity. Minneapolis, MN: University of Minnesota Press.

Cohen, W. I. (2000). East Asia at the center: Four thousand years of engagement with the world. New York, NY: Columbia University Press.

Dazai, O. (1946). Henji [Reply]. Retrieved from http://www.aozora.gr.jp/cards/000035/files/42372_15885.html 
De Bary, W. T. (2005). Rural land reform directive. In W. Theodore De Bary, C. Gluck, \& A. E. Tiedemann, (Eds.), Sources of Japanese tradition 1600 to 2000 (2nd ed., pp. 1043-1045). New York, NY: Columbia University Press.

Desser, D. (1983). The samurai films of Akira Kurosawa. Ann Arbor, MI: UMI Research Press.

Dower, J. (1969). The eye of the beholder: Background notes on the US-Japan military relationship. Bulletin of Concerned Asian Scholars, 2(1), 15-29.

Dower, J. W. (1999). Embracing defeat: Japan in the wake of World War II. New York, NY: W.W. Norton \& Co.

Eatwell, R. (1999). Introduction: What are political ideologies? In R. Eatwell \& A. Write (Eds.), Contemporary political ideologies (pp. 1-22). New York, NY: Pinter.

Eldridge, R. D. (2008). The revision of the US-Japan security treaty and Okinawa: Factional and domestic political constraints on Japanese diplomacy in the 1950s. In M. Iokibe, C. Rose, J. Tomaru, \& J. Weste (Eds.), Japanese Diplomacy in the 1950s: From isolation to integration (pp. 164-176). New York, NY: Routledge.

Fierke, K. M. (2007). Critical approach to international security. Cambridge: Polity Press.

Fouse, D. (2004). Japan's post-Cold War North Korea policy: Hedging toward autonomy? Asia Pacific Center for Security Studies. Retrieved from http://www.apcss.org/Publications/Ocasional\%20Papers/OPJapansPostColdWarNorthKoreaPolicy.pdf

Funabashi, Y., \& Council on Foreign Relations. (1999). Alliance adrift. New York, NY: Council on Foreign Relations Press.

Hansen, L. (2006). Security as practice: Discourse analysis and the Bosnian war. New York, NY: Routledge.

Hatano, I. (1951). Shōnenki [Boyhood]. Tokyo: Kōbunsha.

He, Y. (2007). Remembering and forgetting the war: Elite mythmaking, mass reaction, and Sino-Japanese relations, 1950-2006. History \& Memory, 19(2), 43-74.

High, P. (2003). The imperial screen: Japanese film culture in the Fifteen Year's War 1931-1945. Madison, WI: The University of Wisconsin Press.

Hopf, T. (2002). Social construction of international politics: Identities \& foreign policies, Moscow, 1955 and 1999. Ithaca, NY: Cornell University Press. 
Hughes, C. W. (2004). Japan's re-emergence as a 'normal' military power. Oxford: Oxford University Press.

Ikehata, S., \& Yu-Jose, L. (2003). Philippines-Japan relations. Manila: Ateneo De Manila University Press.

Imperial Rescript. (1941). Retrieved from http://www.ioc.u-tokyo.ac.jp/ worldjpn/

Ishigaki, A. (1953). Mirage over the desert. In V. Otake \& D. G. Haring (Eds.), Japan looks back on the occupation. Far Eastern Survey, 22(3), 26-32.

Jacobini, H. B. (1961). Main patterns of Philippine foreign policy. The Review of Politics, 23(4), 507-530.

Japan Economic Planning Agency. (1956). Nenji Keizai Houkoku [Economic White Paper]. Retrieved from http://www5.cao.go.jp/keizai3/keizaiwp/wp-je56/wp-je56010501.html

Japan Defense Agency. (2005). Defense of Japan 2005: Annual Defense White Paper.

Japan-Republic of Korea joint declaration: A new Japan-Republic of Korea partnership towards the twenty-first century (1998). Retrieved from http://www.mofa.go.jp/region/asia-paci/korea/joint9810.html

Katzenstein, P. J., and Okawara, N. (1993). Japan's national security: Structures, norms and policy responses in a changing world. International Security, 17(4), 84-118.

Kingston, J. (2004). Japan's quiet transformation: Social change and civil society in the twenty-first century. London: Routledge.

Koizumi, J. (2001a, May 7). Policy speech by Prime Minister Junichirō Koizumi to the $151^{\text {st }}$ Session of the Diet. Retrieved from http://www.mofa.go.jp/announce/pm/koizumi/speech0105.html

Koizumi, J. (2001b, September 12). Statement by the Prime Minister of Japan. Retrieved from http://www.mofa.go.jp/announce/pm/koizumi/state0912.html

Koizumi, J. (2001c, September 23). Remarks by Prime Minister Junichirō Koizumi at the ceremony for all victims of terrorist attacks in U.S. Retrieved from http://www.mofa.go.jp/region/n-america/us/terro0109/010923_e.html

Koizumi, J. (2002, January 4). Opening statement by Prime Minister Junichirō Koizumi at the press conference. Retrieved from http://japan.kantei.go.jp/koizumispeech/2002/01/04kisya_e.html 
Koizumi, J. (2003a, March 18). Press conference by Prime Minister Junichirō Koizumi. Retrieved from http://www.mofa.go.jp/region/middle_e/iraq/issue2003/pmpress0312.html

Koizumi, J. (2003b, March 20). Press conference by Prime Minister Junichirō Koizumi on the Issue of Iraq. Retrieved from http://japan.kantei.go.jp/koizumispeech/2003/03/20kaiken_e.html

Koizumi, J. (2003c, December 9). Press conference by Prime Minister Junichirō Koizumi: The Basic Plan regarding the measures based on the Law Concerning the Special Measures on Humanitarian and Reconstruction Assistance in Iraq. Retrieved from http://japan.kantei.go.jp/koizumispeech/2003/12/09press_e.html

Koizumi, J. (2005a, January 21). General policy speech by Prime Minister Junichirō Koizumi to the $162^{\text {nd }}$ session of the Diet. Retrieved from http://www.mofa.go.jp/announce/pm/koizumi/speech0501.html

Koizumi, J. (2005b, December 8). Press conference by Prime Minister Junichirō Koizumi. Retrieved from http://japan.kantei.go.jp/koizumispeech/2005/12/08press_e.html

Koseki, S. (2002). Heiwakokka nihon no saikentō [Reconsidering the pacifist country, Japan]. Tokyo: Iwanamishoten.

Kowert, P. (2001). Toward a constructivist theory of foreign policy. In V. Kubalkova \& R. Pettman (Eds.), Foreign Policy in a Constructed World (pp. 266-287). Armonk, NY: M. E. Sharpe.

Kunihiro, M. (1997). The decline and fall of pacifism. Bulletin of the atomic science 53, 35-39.

Langdon, F. (1973). Japan's foreign policy. Vancouver: University of British Columbia Press.

Leng, S. C. (1958). Japan and communist China. Kyoto: Doshisha University Press [distributed in the U.S. by the Institute of Pacific Relations, New York].

Liberal Democratic Party. (1955). Rittou Sengen [Declaration of formation of party]. Retrieved from https://www.jimin.jp/aboutus/declaration/index.html.

Lind, J. (2004). Pacifism or passing the buck? Testing theories of Japanese security policy. International Security, 29(1), 92-121.

Mannheim, K. (1936). Ideology and utopia: An introduction to the sociology of knowledge. New York, NY: Harcourt, Brace and Company.

McCormack, G. (2007). Client state: Japan in the American embrace. London: Verso. 
Mearsheimer, J. J. (2001). The tragedy of great power politics. New York, NY: Norton.

Ministry of Foreign Affairs of Japan. (1957). Diplomatic Bluebook.

Ministry of Foreign Affairs of Japan. (1993). Diplomatic Bluebook.

Ministry of Foreign Affairs of Japan. (2006). Diplomatic Bluebook.

Ministry of Health, Labor and Welfare. (1956). Kousei Hakusho [White paper on health and health care].Retrieved from http://wwwhakusyo.mhlw.go.jp/wp/index.htm

Morley, J. W. (1962). Japan's image of the Soviet Union 1952-1961. Pacific Affairs, $35(1), 51-58$.

Mutō, U. (1953) Democracy and chastity. In V. Otake \& D. G. Haring (Eds.), Japan looks back on the occupation. Far Eastern Survey, 22(3), 26-32.

Obuchi, K. (1999). Policy speech by Prime Minister Keizo Obuchi to the $145^{\text {th }}$ Session of the Diet. Retrieved from http://japan.kantei.go.jp/souri/990121 policy-speech.html

Oda, S. (1967). The normalization of relations between Japan and the Republic of Korea. The American Journal of International Law, 61(1), 35-56.

Oguma, E. (2002). Minshu to aikoku: Sengo Nihon no nashonarizumu to kōkyō [Democracy and patriotism: Japan's nationalism after the World War II and the public space]. Tokyo: Shinyōsha.

Oros, A. (2008). Normalizing Japan: Politics, identity, and the evolution of security practice. Stanford, CA: Stanford University Press.

Osaragi, J. (1954). Kikyō [Homecoming]. Tokyo; Shinchōbunko.

Otake, V., \& Haring, D. G. (1953). Japan looks back on the occupation. Far Eastern Survey, 22(3), 26-32.

Park, G \& Vogel, S. (2007). Japan in 2006: A political transition. Asian Survey, 47(1), 22-31.

Patton, C. (2007). Cinematic identity: Anatomy of a problem film. Minneapolis, MN: University of Minnesota Press.

Pyle, K. B. (2007). Japan rising: The resurgence of Japanese power and purpose. New York, NY: Public Affairs.

Ryu, S. (1950). Monono mikatani tsuite [On a way to read: What to learn from the West]. Japan: Kawaide Shobō. 
Ryan, M., \& Kellner, D. (1990). Camera politica: The politics and ideology of contemporary Hollywood film. Bloomington, IN: Indiana University Press.

Saikaku, I. (1686). Kōshoku ichidai onna [The Life of an Amorous Woman].

Sakaguchi, A. (1946). Zoku Darakuron [Later Decadence]. Shūkan Shinchō, 43(4). Retrieved from http://www.aozora.gr.jp/cards/001095/files/42619_21409.html

Sakaguchi, A. (1947). Pan-Pan Garu [Pan-pan girl]. All Yomimono, 2(8). Retrieved from http://www.aozora.gr.jp/cards/001095/files/42876_34345.html

Samuels, R. J. (2007). Securing Japan: Tokyo's grand strategy and the future of East Asia. New York, NY: Cornell University Press.

Satō, T. (1982). Currents in Japanese cinema: Essays. New York, NY: Kodansha International.

Security treaty between Japan and the United States of America, Japan-the U.S., September 8, 1951. Retrieved from http://www.ioc.utokyo.ac.jp/ worldjpn/documents/texts/docs/19510908.T2E.html

Seekins, D. M. (2007). Burma and Japan since 1940: From 'co-prosperity' to 'quiet dialogue'. Copenhagen: Nordic Institute of Asian Studies.

Shibusawa, N. (2006). America's geisha ally: Reimagining the Japanese enemy. Cambridge, MA: Harvard University Press.

Shimazu, N. (2003). Popular Representations of the Past: The case of postwar Japan. Journal of Contemporary History, 38(1), 101-116.

Shinoda, T. (2007). Koizumi diplomacy: Japan's kantei approach to foreign and defense affairs. Seattle, WA: University of Washington Press.

Standish, I. (2000). Myth and masculinity in the Japanese cinema: Towards a political reading of the "tragic hero." Richmond, WA: Curzon.

Strefford, P. (2010). How Japan's post-war relationship with Burma was shaped by aid. Asian Affairs, XLI(1), 35-45.

Swenson-Wright, J. (2008) The lucky dragon incident of 1954: A failure of crisis management? In M. Iokibe, C. Rose, J. Tomaru, \& J. Weste (Eds.), Japanese Diplomacy in the 1950s: From isolation to integration (pp. 139-153). New York, NY: Routledge.

Tanizaki, J. (1948/1983). Sasameyuki [The Makioka Sisters]. Tokyo: Chuōkōron Shinsho. 
Taylor, C. (2002). Modern social imaginaries. Public Culture, 14, 91-124.

Tōgō, K. (2005). Japan's foreign policy 1945-2003: The quest for proactive policy. Boston, MA: Brill.

Tōgō, K. (2010). Japan's foreign policy, 1945-2009: The quest for a proactive policy. Boston, MA: Brill.

Yang, I. (2002). "Yakuza" eiga ni okeru "Zainichi” kan. [The representation of "Zainichi” in yakuza films]. Ritsumeikansangyōshakaironshū, 38(2), 113-130.

Waltz, N. K. (1993). The emerging structure of international politics. International Security, 18(2), 44-79.

Weber, C. (2005). International relations theory: A critical introduction ( $2^{\text {nd }}$ ed.). New York, NY: Routledge.

Weber, C. (2006). Imagining America at war: Morality, politics, and film. New York, NY: Routledge.

Weinstein, M. E. (1971). Japan's postwar defense policy, 1947-1968. New York, NY: Columbia University Press.

Zhou, P. (2005). Military mayhem: The decline in Japanese pacifism. Harvard International Review, 27(2), 10-11. 
VITA

YUKARI ITO

Born, TOKYO, JAPAN

1995-1999

B.A., Policy Management

Keio University

Kanagawa, Japan

1999-2001

M.A., Media and Governance

Keio University Graduate School of Media and

Governance

Kanagawa Japan

2002-2004

M.A., Public Policy

University of Northern Iowa

Cedar Falls, Iowa

2005-2007

Teaching Assistant

Department of International Relations and Geography

Florida International University

Miami, Florida

2004-2008

M.A., International Studies

Department of International Relations and Geography

Florida International University

Miami, Florida

$2008-2015$

Doctoral Candidate

Department of International Relations and Geography

Florida International University

Miami, Florida

\section{PUBLICATIONS AND PRESENTATIONS}

Ito, Y. (2009). Rethinking 'Cooperation': A Reflection on Security Relations between Japan and South Korea. Japan Studies (Research Center of Japanese Studies Korea), 12, 377-398.

Ito, Y. (2009, February). Making Sense of Japan's Security/Defense Policies in the PostCold War Era. Paper presented at International Studies Association $50^{\text {th }}$ Annual 
Convention, New York, New York: Perceptions and Misperceptions in SinoJapanese Relations.

Ito, Y. (2007, February). Pacifism or Militarism?: The Experiences and Lessons of Japan's Military Humanitarian Interventions in the Post-Cold War era. Paper presented at International Studies Association $48^{\text {th }}$ Annual Convention, Chicago, Illinois: Politics, Policy and Responsible scholarship: Post-Conflict Spaces in IR (3): World Politics.

Ito, Y. (2006, February). The Quest for Obligation: The World Bank and Human Rights. Paper presented at Florida International University mini Conference: The War Crimes and International Responsibility: A Symposium on Human Rights, Law and Governance at Florida International University. 